ENVIRONMENTAL RESTORATION

PROGRAM

\title{
Decision Document for Performing a Long-Term Pumping Test at the S-3 Site, Oak Ridge Y-12 Plant, Oak Ridge, Tennessee
}

\section{DISCLAIMER}

This report was prepared as an account of work sponsored by an agency of the United States Government. Neither the United States Government nor any agency thereof, nor any of their employees, makes any warranty, express or implied, or assumes any legal liability or responsibility for the accuracy, completeness, or usefulness of any information, apparatus, product, or process disclosed, or represents that its use would not infringe privately owned rights. Reference herein to any specific commercial product, process, or service by trade name, trademark, manufacturer, or otherwise does not necessarily constitute or imply its endorsement, recommendation, or favoring by the United States Government or any agency thereof. The views and opinions of authors expressed herein do not necessarily state or reflect those of the United States Government or any agency thereof.

\section{MANAGED BY}

MARTIN MARIETTA ENERGY SYSTEMS, INC. 


\section{Science Applications International Corporation}

contributed to the preparation of this document and should not be considered an eligible contractor for its review.

This report has been reproduced directly from the best available copy.

Available to DOE and DOE contractors from the Office of Scientific and Technical Information, P.O. Box 62, Oak Ridge, TN 37831; prices available from 615-576-8401 (fax 615-576-2865).

Available to the public from the National Technical Information Service, U.S. Department of Commerce, 5285 Port Floyal Rd., Springfield, VA 22161. 


\section{DISCLAIMER}

Portions of this document may be illegible in electronic image products. Images are produced from the best available original document. 
March 2, 1995

Ms. Sherry L. Lankford, Manager

Y-12 Environmental Restoration Program

Department of Energy, Oak Ridge Operations

Post Office Box 2001

Oak Ridge, Tennessee 37830-8501

Dear Ms. Lankford:

Transmittal of Decision Document for Performing a Long-Term Pumping Test at the S-3 Site, Y12 Plant, Oak Ridge, Tennessee (Y/ER-210)

Please find enclosed 10 copies of the Decision Document for Performing a Long-Term Pumping Test (LTPT) at the S-3 Site. This document evaluates the need for a long-term pumping test to assess the use of this technology for remediation of the S-3 groundwater plume. Based on information presented in this document, it is not recommended that a pumping test be implemented at this time. The primary reasons for this recommendation are:

1. The ability to treat technetium and nitrates in groundwater generated by a pumping test at the S-3 site is uncertain.

2. Implementation of a pumping test will not significantly reduce uncertainty associated with the site characteristics identified by the Environmental Protection Agency (EPA) as contributors to the success or failure of a pump and treat action (Attachment 1). Of the six characteristics identified as having a high level of uncertainty, only uncertainty associated with the medium could be significantly reduced by an LTPT.

3. Other less costly studies can be performed which will better reduce uncertainties regarding the effectiveness of pump and treat for remediation.

In lieu of the LTPT, it is recommended that additional support be provided to two portions of an ongoing research and development project titled "Pumping and Multiple Tracer Test." This project is conducted under the auspices of the Energy Systems Groundwater Programs Office and represents a funded activity that will evaluate many of the uncertainties highlighted in Attachment 1. Specifically, results of this project will address: (1) contaminant retardation potential; (2) the role and importance of matrix diffusion in the regolith and shallow bedrock; and (3) contaminant mobility questions. While project results will not eliminate all uncertainty surrounding these issues, they will significantly reduce uncertainty. By providing support in the range of $\$ 40$ to $\$ 50 \mathrm{~K}$ so that the scope of the ongoing project is modified slightly, Y-12 Environmental Restoration (ER) can capitalize on the results of a long-term study and on funding provided by other sources. At this point in time, offering additional financial support to such an ongoing study offers the most cost-effective means to further reduce general 
Ms. Sherry L. Lankford

Page 2

March 2, 1995

uncertainties regarding the performance and applicability of pump-and-treat groundwater remediation technologies at the Y-12 Plant.

Please sign and return the attached acknowledgment form and forward the appropriate number of copies of this document to the EPA and Tennessee Department of Environment and Conservation (TDEC) for their review. You may contact Judy Hodgins at 576-2368 with any questions you may have.

Sincerely,

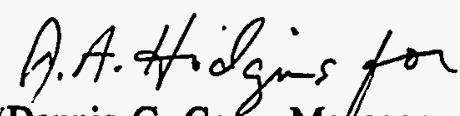

Dennis G. Cope, Mahager

Y-12 Environmental Restoration Program

DGC:JAHodgins:lsh

Enclosure

cc: C. S. Haase

J. A. Hodgins

W. K. Jago

H. L. King

L. W. McMahon

B. D. Nourse

T. Pickens, SAIC

C. S. Walker

D. B. Watson

File-ER Document Management Center-RC

File-Y-12 ER Program-NoRC 
Ms. Sherry L. Lankford

Page 3

March 2, 1995

I acknowledge receipt of 10 copies of the document listed below and will transmit the required number of copies of this document to EPA and TDEC.

Sherry L. Lankford, Y-12 ER Program Manager

Date of Signature

Environmental Restoration Division

Document: Decision Document for Performing a Long-Term Pumping Test at the S-3 Site, Y-12 Plant, Oak Ridge, Tennessee (Y/ER-210) 
Energy Systems Environmental Restoration Program

Y-12 Environmental Restoration Program

\title{
Decision Document for Performing \\ a Long-Term Pumping Test at the S-3 Site, Oak Ridge Y-12 Plant, Oak Ridge, Tennessee
}

Date Issued-February 1995

\author{
Prepared by \\ Science Applications International Corporation \\ Oak Ridge, Tennessee \\ under subcontract $18 \mathrm{~B}-99069 \mathrm{C}$ \\ Prepared for \\ U.S. Department of Energy
}

Office of Environmental Restoration and Waste Management under budget and reporting code EW 20

Environmental Restoration and Waste Management Programs OAK RIDGE Y-12 PLANT

Oak Ridge, Tennessee 37831-8169

managed by

MARTIN MARIETTA ENERGY SYSTEMS, INC.

for the

U.S. DEPARTMENT OF ENERGY

under contract DE-AC05-84OR21400 


\section{PREFACE}

This decision document on conducting a groundwater long-term pumping test at the S-3 Site at the Oak Ridge Y-12 Plant was prepared to support the evaluation of remedial alternatives in the Bear Creek Valley operable unit feasibility study report. This work was prepared under work breakdown structure 1.4.12.1.1.02.11 (Activity Data Sheet 2302, Bear Creek). This document is not a Federal Facility Agreement milestone deliverable. 



\section{CONTENTS}

PREFACE $\ldots \ldots \ldots \ldots \ldots \ldots \ldots \ldots \ldots \ldots \ldots \ldots \ldots \ldots \ldots \ldots \ldots \ldots \ldots \ldots \ldots$

FIGURES $\ldots \ldots \ldots \ldots \ldots \ldots \ldots \ldots \ldots \ldots \ldots \ldots \ldots \ldots \ldots \ldots \ldots$ ix

TABLES $\ldots \ldots \ldots \ldots \ldots \ldots \ldots \ldots \ldots \ldots \ldots \ldots \ldots \ldots \ldots \ldots \ldots \ldots \ldots$

ACRONYMS $\ldots \ldots \ldots \ldots \ldots \ldots \ldots \ldots \ldots \ldots \ldots \ldots \ldots \ldots \ldots \ldots \ldots \ldots \ldots \ldots$

EXECUTIVE SUMMARY $\ldots \ldots \ldots \ldots \ldots \ldots \ldots \ldots \ldots \ldots \ldots \ldots \ldots \ldots$

1. INTRODUCTION $\ldots \ldots \ldots \ldots \ldots \ldots \ldots \ldots \ldots \ldots \ldots \ldots \ldots \ldots \ldots \ldots \ldots$

1.1 SCOPE AND OBJECTIVES ..................... 1-1

1.2 PHASE I LTPT DATA QUALITY OBJECTIVES ............ 1-3

1.2.1 Statement of Problem ....................... 1-4

1.2.2 Decisions to be Made ....................... 1-4

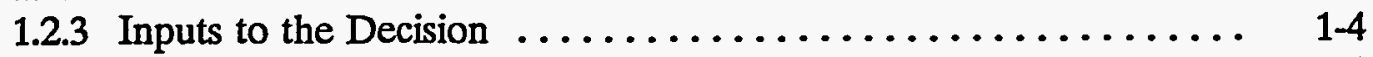

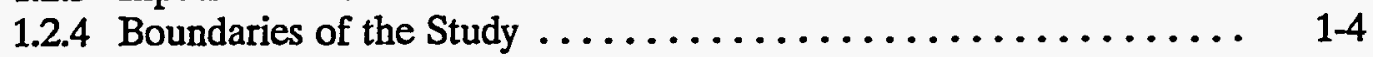

1.2 .5 Decision Rules ......................... 1-6

1.2.6 Uncertainty Constraints $\ldots \ldots \ldots \ldots \ldots \ldots \ldots \ldots \ldots \ldots \ldots \ldots$ 1-6

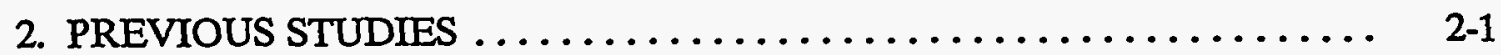

2.1 HYDRAULIC MEDIA CHARACTERISTICS ............. 2-1

2.1.1 Geologic Description ...................... 2-1

2.1.2 Hydraulic Characteristics of the Nolichucky Shale ......... 2-3

2.2 HYDRAULIC TESTING RESULTS ................. 2-6

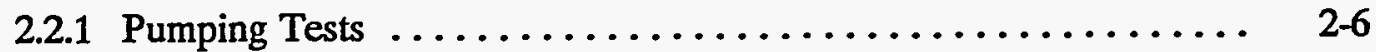

2.2.2 Slug Testing $\ldots \ldots \ldots \ldots \ldots \ldots \ldots \ldots \ldots \ldots \ldots \ldots \ldots \ldots . \ldots \ldots$

2.2 .3 Tracer Testing $\ldots \ldots \ldots \ldots \ldots \ldots \ldots \ldots \ldots \ldots \ldots \ldots \ldots \ldots . \ldots \ldots$

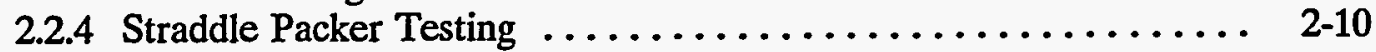

2.2.5 Hydraulic Testing Summary .................. 2-10

2.3 SOURCE CHARACTERIZATION: S-3 PONDS

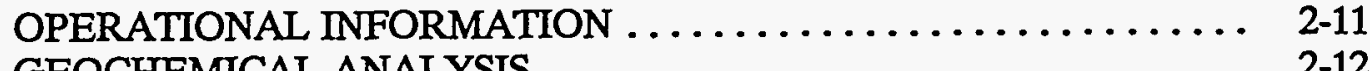

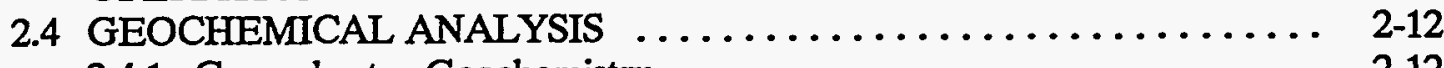

2.4.1 Groundwater Geochemistry ................... 2-12

2.4.2 Contaminant Geochemistry ................... 2-14

2.5 FLOW AND CONTAMINANT TRANSPORT MODELS $\ldots \ldots \ldots \ldots . \quad 2-17$

2.6 UNCERTAINTY SUMMARY ................... 2 .18

3. SITE CONCEPTUAL MODEL ..................... 3-1

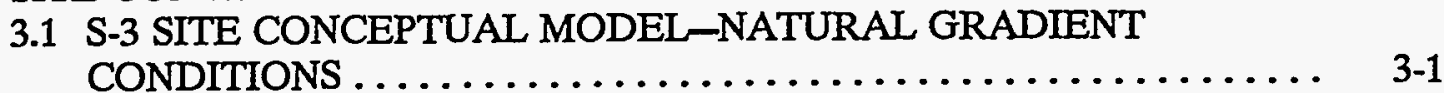

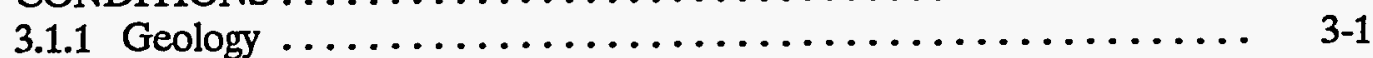

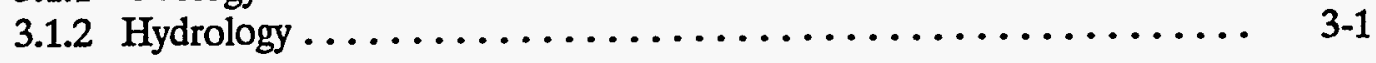


3.1.3 Contaminant Transport $\ldots \ldots \ldots \ldots \ldots \ldots \ldots \ldots \ldots \ldots \ldots, 3-2$

3.1.4 Pathways ................................ $3-7$

3.2 S-3 SITE CONCEPTUAL MODEL-RESPONSE TO PUMPING .... 3-8

4. PUMPING TEST DESIGN $\ldots \ldots \ldots \ldots \ldots \ldots \ldots \ldots \ldots \ldots \ldots, 4,1$

4.1 TEST OBJECTIVES $\ldots \ldots \ldots \ldots \ldots \ldots \ldots \ldots \ldots \ldots \ldots \ldots \ldots, 4,1$

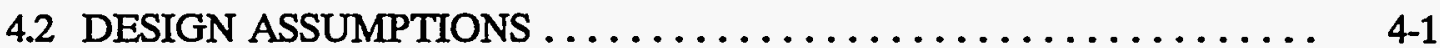

4.3 CAPTURE ZONE MODELING $\ldots \ldots \ldots \ldots \ldots \ldots \ldots \ldots \ldots \ldots, 4,2$

4.4 CONCEPTUAL DESIGN $\ldots \ldots \ldots \ldots \ldots \ldots \ldots \ldots \ldots \ldots \ldots, 4,3$

4.4.1 Selection of Pumping and Observation Wells $\ldots \ldots \ldots \ldots \ldots \ldots$ 4.3

4.4.2 Water Level Measurements $\ldots \ldots \ldots \ldots \ldots \ldots \ldots \ldots \ldots .4 .6 .6$

4.4.3 Chemical Analysis $\ldots \ldots \ldots \ldots \ldots \ldots \ldots \ldots \ldots \ldots \ldots \ldots, \quad 4,9$

4.4.4 Interpretation of the Data $\ldots \ldots \ldots \ldots \ldots \ldots \ldots \ldots \ldots \ldots$. 4-10

5. WASTE MANAGEMENT ISSUES $\ldots \ldots \ldots \ldots \ldots \ldots \ldots \ldots \ldots \ldots$. $5-1$

5.1 GROUNDWATER CONTAMINANTS $\ldots \ldots \ldots \ldots \ldots \ldots \ldots \ldots, 5-1$

5.2 TREATMENT TRAIN $\ldots \ldots \ldots \ldots \ldots \ldots \ldots \ldots \ldots \ldots \ldots \ldots \ldots \ldots, 5,1$

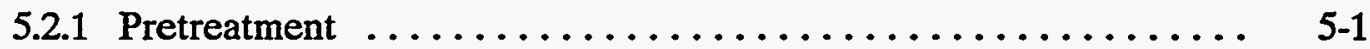

5.2 .2 Transportation $\ldots \ldots \ldots \ldots \ldots \ldots \ldots \ldots \ldots \ldots \ldots, 5, \ldots \ldots \ldots,{ }_{5-3}$

5.2 .3 Hold-Up Storage $\ldots \ldots \ldots \ldots \ldots \ldots \ldots \ldots \ldots \ldots \ldots, \quad 5-3$

5.2 .4 Treatment $\ldots \ldots \ldots \ldots \ldots \ldots \ldots \ldots \ldots \ldots \ldots \ldots \ldots, 5,3$

5.3 REGULATORY ISSUES $\ldots \ldots \ldots \ldots \ldots \ldots \ldots \ldots \ldots \ldots \ldots \ldots \ldots \ldots \ldots, 5-3$

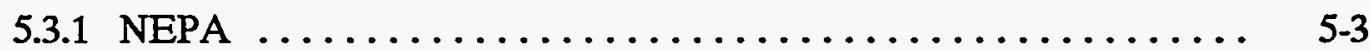

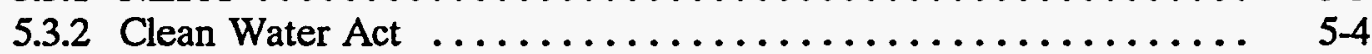

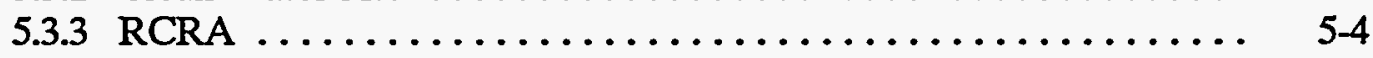

5.3.4 Atomic Energy Act of 1954, as Amended ............. 5-4

5.4 WASTE STREAMS ........................ $5-4$

5.5 TRANSPORTATION, STORAGE, AND TREATMENT
CAPACITY ................................... 5 .5

5.5.1 Transportation Capacity $\ldots \ldots \ldots \ldots \ldots \ldots \ldots \ldots \ldots, 5-5$

5.5 .2 Storage Capacity $\ldots \ldots \ldots \ldots \ldots \ldots \ldots \ldots \ldots \ldots \ldots \ldots, \quad 5-5$

5.5.3 Treatment Capacity $\ldots \ldots \ldots \ldots \ldots \ldots \ldots \ldots \ldots \ldots \ldots, 5-5$

5.6 WASTE MANAGEMENT $\ldots \ldots \ldots \ldots \ldots \ldots \ldots \ldots \ldots \ldots \ldots . \ldots \ldots$

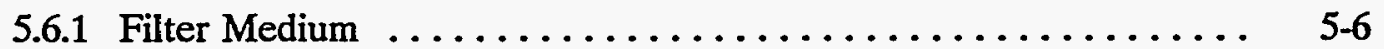

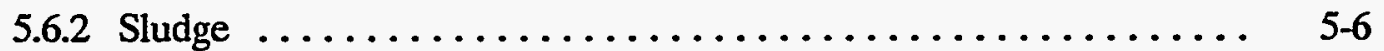

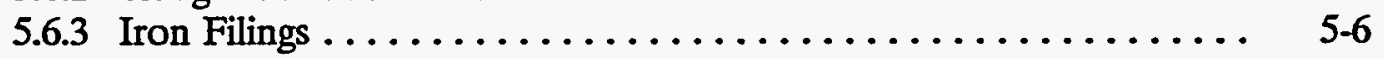

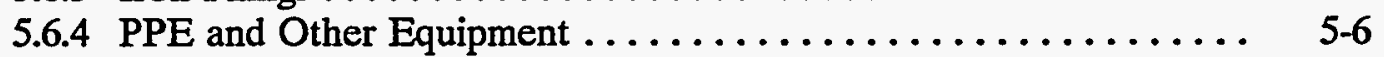

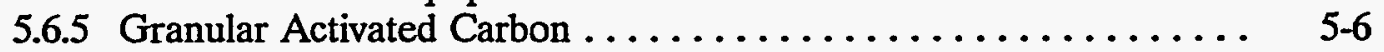

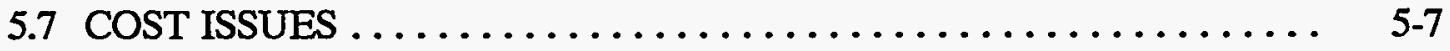

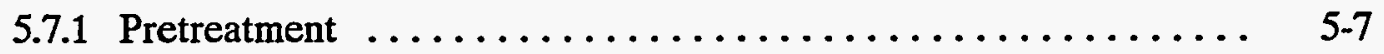

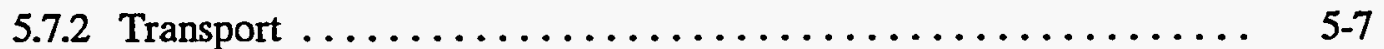

5.7.3 Chemical Operators $\ldots \ldots \ldots \ldots \ldots \ldots \ldots \ldots \ldots \ldots \ldots, 5-7$

5.7 .4 Sampling $\ldots \ldots \ldots \ldots \ldots \ldots \ldots \ldots \ldots \ldots \ldots \ldots \ldots \ldots \ldots \ldots \ldots, 5,7$

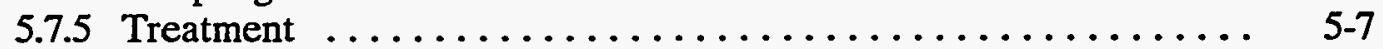


6. HEALTH AND SAFETY CONCERNS AND QUALITY ASSURANCE/QUALITY CONTROL ISSSUES $\ldots \ldots \ldots \ldots \ldots \ldots \ldots \ldots, 6-1$

6.1 HEALTH AND SAFETY CONCERNS $\ldots \ldots \ldots \ldots \ldots \ldots \ldots \ldots .6 \ldots \ldots .6 .1$

6.2 QUALITY ASSURANCE/QUALITY CONTROL ISSUES ......... 6 6-2

6.2.1 Quality Assurance Objectives $\ldots \ldots \ldots \ldots \ldots \ldots \ldots \ldots \ldots, \quad 6.2$

6.2.2 Sampling and Custody Procedures $\ldots \ldots \ldots \ldots \ldots \ldots \ldots \ldots, 6 \ldots \ldots$

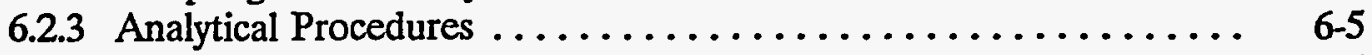

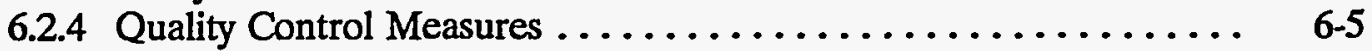

6.2.5 Equipment Calibration and Maintenance $\ldots \ldots \ldots \ldots \ldots \ldots \ldots$ 6.5

6.2.6 Data Management ......................... 6.5

6.2 .7 Quality Assurance Measures.$\ldots \ldots \ldots \ldots \ldots \ldots \ldots \ldots$. 6-6

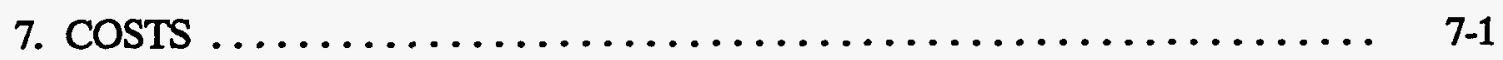

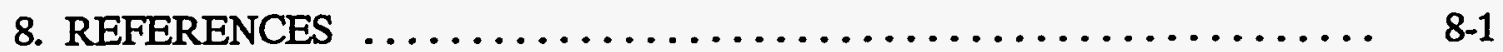

Appendix A. HYDRAULIC PROPERTIES AND SUMMARY

OF EXISTING MODELS 



\section{FIGURES}

1.1 Activity elements and decision points for the S-3 Site LTPT $\ldots \ldots \ldots \ldots$ 1-2

1.2 Factors affecting the success of pumping and treating groundwater $\ldots \ldots . \quad 1-5$

2.1 Site map showing locations of monitoring wells $\ldots \ldots \ldots \ldots \ldots \ldots \ldots, 2-4$

2.2 Hydrologic cross section in strike-perpendicular section (after Dreier et al. 1993) ......................... 2-5

2.3 Locations of the observation wells and the pumping well used during the S-3 Ponds pumping test by Geraghty \& Miller, Inc. (1986) . . . . . . . . 2-7

2.4 East/west cross section showing conditions before and after pumping test conducted on March 24,1986 , in well GW-245 .............. 2-8

2.5 Water-type regimes in strike-perpendicular section (after Dreier et al. 1993) ...............................

2.6 Gross alpha activity in groundwater in the Bear Creek

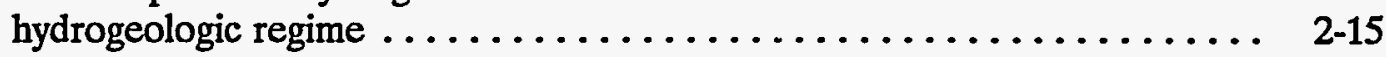

2.7 Gross beta activity in groundwater in the Bear Creek hydrogeologic regime $\ldots \ldots \ldots \ldots \ldots \ldots \ldots \ldots \ldots \ldots \ldots \ldots, 2-16$

2.8 VOCs in groundwater in the vicinity of the S-3 Site $\ldots \ldots \ldots \ldots \ldots \ldots, 2-19$

2.9 Nitrate in groundwater in the Bear Creek hydrogeologic regime ........ 2-21

3.1 S-3 Site conceptual model for groundwater flow and

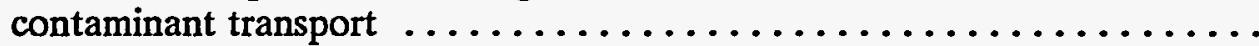

3.2 Detail of the S-3 Site conceptual model for groundwater flow and contaminant transport showing the shallow flow system ...........

3.3 Conceptual model for the cone of depression response to a pumping well (a) connected to the active flow fracture network and (b) poorly connected to the active flow fracture network ..........

4.1 Projected drawdown curves at the end of $1 \mathrm{~d}$ of pumping at the rate

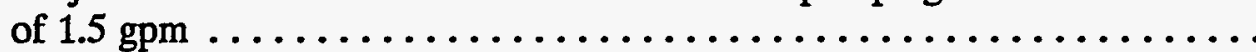

4.2 Projected drawdown curves at the end of $10 \mathrm{~d}$ of pumping at the rate

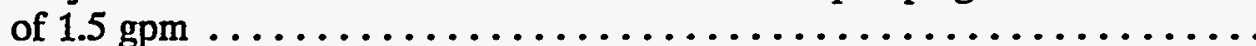

4.3 Stratigraphic position of monitoring well screen zones in the vicinity

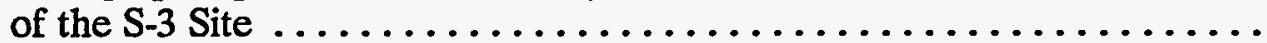





\section{TABLES}

2.1 Stratigraphy of the Y-12 Plant area (after Solomon et al. 1992) . . . . . . 2-2

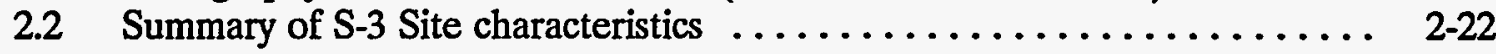

4.1 Parameter values used in the pumping test design ............ 4-2

4.2 Results of sensitivity analysis based on $30-\mathrm{d}$ pumping at a constant rate of $1.5 \mathrm{gpm} \ldots \ldots \ldots \ldots \ldots \ldots \ldots \ldots \ldots \ldots . \ldots . \ldots$

4.3 Existing wells selected as monitoring wells for the pumping test . . . . . . 4 4-9

4.4 Range of intervals between the water level measurements . . . . . . . . 4 4-10

6.1 Modular profile and cross-reference of EPA QAMS-005/80 and ES/ER/TM-4/R4 elements . . . . . . . . . . . .

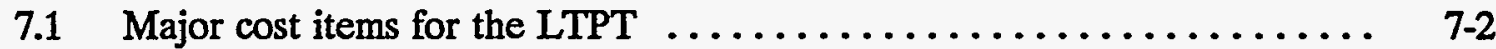

A.1 Hydraulic testing results summary .................... A-3

A.2 Packer test results from Golder and Associates .............. A-5

A.3 Summary of primary flow and contaminant transport models for the S-3 Site . . . . . . . . . . . . . . . . . . . . . .

A.4 Summary of calibrated hydraulic conductivities of the USGS and Geraghty \& Miller, Inc. models ..................... A-10 


$\begin{array}{ll}\text { bgs } & \text { below ground surface } \\ \text { CFR } & \text { Code of Federal Regulations } \\ \text { CX } & \text { categorical exclusion } \\ \text { DOE } & \text { U.S. Department of Energy } \\ \text { DQO } & \text { data quality objective } \\ \text { Energy Systems } & \text { Martin Marietta Energy Systems, Inc. } \\ \text { EPA } & \text { U.S. Environmental Protection Agency } \\ \text { ER } & \text { Environmental Restoration } \\ \text { ESPs } & \text { Environmental Surveillance Procedures } \\ \text { GWQAR } & \text { Groundwater Quality Assessment Report } \\ \text { LTPT } & \text { long-term pumping test } \\ \text { MODFLOW } & \text { Modular Three-Dimensional Finite-Difference Groundwater Flow } \\ & \text { Model } \\ \text { NEPA } & \text { National Environmental Policy Act } \\ \text { NPDES } & \text { National Pollutant Discharge Elimination System } \\ \text { OREIS } & \text { Oak Ridge Environmental Information System } \\ \text { PARCC } & \text { precision, accuracy, representativeness, completeness, and } \\ & \text { comparability } \\ \text { PHREEQE } & \text { pH-redox-equilibrium-equations } \\ \text { PPE } & \text { personal protective equipment } \\ \text { RCRA } & \text { Resource Conservation and Recovery Act } \\ \text { RMS } & \text { root mean square } \\ \text { RMSE } & \text { root mean square error } \\ \text { SWIFT } & \text { Sandia Waste Isolation Flow and Transport Model } \\ \text { TCLP } & \text { toxicity characteristic leaching procedure } \\ \text { UEFPC } & \text { Upper East Fork Poplar Creek } \\ \text { VOCs } & \text { volatile organic compounds } \\ \text { WATEQF } & \text { water equilibrium-FORTRAN } \\ \text { WETF } & \text { West End Treatment Facility }\end{array}$





\section{EXECUTIVE SUMMARY}

One of the principal problems confronting the remediation of Bear Creek Valley is the cleanup of contaminated groundwater. The S-3 Site is one of the locations in the valley where groundwater is most contaminated, and contamination from the S-3 Site has also caused extensive contamination of downgradient groundwater. This groundwater plume, therefore, has a high priority in the Bear Creek Valley remedial process.

Pumping and treating groundwater was identified early in the feasibility study as a likely remedial alternative for the S-3 Site groundwater plume. The hydrology and geochemistry of the plume are extremely complex. There is a high degree of uncertainty in the current understanding of how the aquifer will react physically and chemically to pumping, making evaluation of a pump-and-treat alternative impractical at the present time. Before a pumpand-treat alternative can be evaluated, its technical practicability, effectiveness, and projected cost must be determined. A long-term pumping test (LTPT) at the S-3 Site has been proposed so that the information necessary to carry out this evaluation can be collected. This document constitutes the first phase in the planning process for this test.

The following phased approach to the LTPT is being used: Phase 1 (this document), a technical evaluation of LTPT using currently available data; Phase $\Pi$, preparation of a detailed LTPT work plan; Phase III, implementation of the LTPT work plan; and Phase IV, analysis and reporting of the LTPT. The phased approach incorporates a decision point at which the option to implement the LTPT will be decided. The LTPT will be implemented if (1) existing data cannot prove that pump-and-treat technology is impractical for groundwater remediation at the S-3 Site or (2) an LTPT will provide information that will reduce the uncertainty of evaluating pump-and-treat technology as a remedial alternative. If it is determined that an LTPT cannot sufficiently improve the practicability of evaluating pumpand-treat technology as a remedial alternative, the decision will be made not to implement the LTPT.

The scope of this document is to evaluate the existing hydrological and geochemical data for Bear Creek Valley (the S-3 Site, in particular) and to present these data in a form that can be used by decision makers. In this document Chap. 1 describes the purpose of the document and evaluates the data quality objectives for the LTPT work plan, Chap. 2 contains an evaluation of existing hydrological and geochemical data for the S-3 Site, Chap. 3 is the site conceptual model for the S-3 Site and contains a conceptual model for pumping the aquifer, Chap. 4 is a conceptual design for the LTPT, Chap. 5 summarizes waste management issues that must be dealt with, Chap. 6 summarizes health and safety issues that will also be dealt with, and Chap. 7 presents major cost items.

The S-3 Site is located at the western end of the Oak Ridge Y-12 Plant and on the Nolichucky Shale Formation. Groundwater is contaminated with nitrate, metals, volatile organic compounds, and radionuclides in a plume that extends down the valley from the S-3 Site. The bulk of the contamination is contained in the Nolichucky Shale close to the S-3 Site, and it is this component of the plume that is the target of the LTPT. The Nolichucky Shale is a fine-grained formation with little or no intergranular porosity or hydraulic conductivity. The formation is extensively fractured, and groundwater movement through the fracture 
network dominates groundwater flow and contaminant transport. Conceptually, most groundwater flow is through a shallow system of relatively open fractures, most of which are oriented parallel to bedding planes. There is a high degree of uncertainty concerning the extent of connectivity of these active flow fractures and their locations. This translates into uncertainty about the capture zone of pump-and-treat extraction wells in the Nolichucky Shale.

The process of matrix diffusion has a very strong effect on contaminant transport in the Nolichucky Shale. This process, where most contaminants are in water contained in fractures or matrix porosity that is poorly connected to the active flow system, has the effect of retarding contaminants migrating through the subsurface. There is a high degree of uncertainty concerning the effects of the matrix diffusion process on contaminant transport during groundwater extraction. This translates into uncertainty about the rate at which contaminant mass reduction will occur during pump-and-treat activities.

The major waste management concern associated with conducting an LTPT is pretreating the water before transporting it to the West End Treatment Facility. This pretreatment will be needed to reduce suspended solids content and radiological constituents from the water.

Major cost items are identified based on the major activities associated with the LTPT. The total of these cost items is $\$ 810,890$. 


\section{INTRODUCTION}

One of the principal problems confronting the remediation of Bear Creek Valley is the cleanup of contaminated groundwater. The S-3 Site is one of the locations in the valley where groundwater is most contaminated. In addition, contaminants at the S-3 Site have migrated hundreds of feet from the source (HSW 1994a). For this reason, the S-3 Site groundwater plume has high priority in the Bear Creek Valley remedial investigation/feasibility study process.

The S-3 Site has complex groundwater contamination problems involving multiple contaminants within a fracture flow system. At such sites, it is difficult to determine whether pump-and-treat technology would achieve the required cleanup levels in a cost-effective manner (EPA 1993). Thus, before a pump-and-treat alternative can be evaluated for cleanup, its technical practicability, effectiveness, and cost must be determined. A phased approach is being pursued to facilitate the collection of information necessary to carry out this evaluation. This phased approach incorporates a decision point that provides an option to conduct a longterm pumping test (LTPT) if (1) existing data cannot prove that pump-and-treat technology is impractical for groundwater remediation at the S-3 Site or (2) an LTPT will provide information that can be used to evaluate the pump-and-treat alternative. This document summarizes the existing data and identifies the areas of high uncertainty associated with evaluating pump-and-treat technology so that an informed decision on whether to conduct an LTPT can be made.

\subsection{SCOPE AND OBJECTIVES}

This report is a decision document and uses existing information to evaluate the uncertainties associated with pump-and-treat technology. This document will be used by Martin Marietta Energy Systems, Inc. (Energy Systems), the U.S. Department of Energy (DOE), and the regulatory agencies as they decide whether to proceed with the LTPT project. If this document indicates that pumping and treating contaminated groundwater may be a viable alternative and that an LTPT would provide the data necessary to evaluate pumpand-treat technology as a remedial alternative, a work plan will be prepared and implemented. The approach, which is presented in Fig. 1.1, is outlined as follows:

- Phase I. The technical evaluation section of the LTPT work plan will be prepared during this phase. Activities in this phase will include identifying data gaps, uncertainties associated with data gaps, and possible methods of obtaining data; preparing a conceptual design for the proposed test; preparing a preliminary cost estimate for the LTPT; and briefly discussing waste management, health and safety, and quality assurance issues. The intent of this report is to satisfy the requirements of Phase I.

- Phase II. Phase II will be implemented at the end of Phase I if the decision is made to proceed with the test. This phase will involve preparing a detailed work plan. 


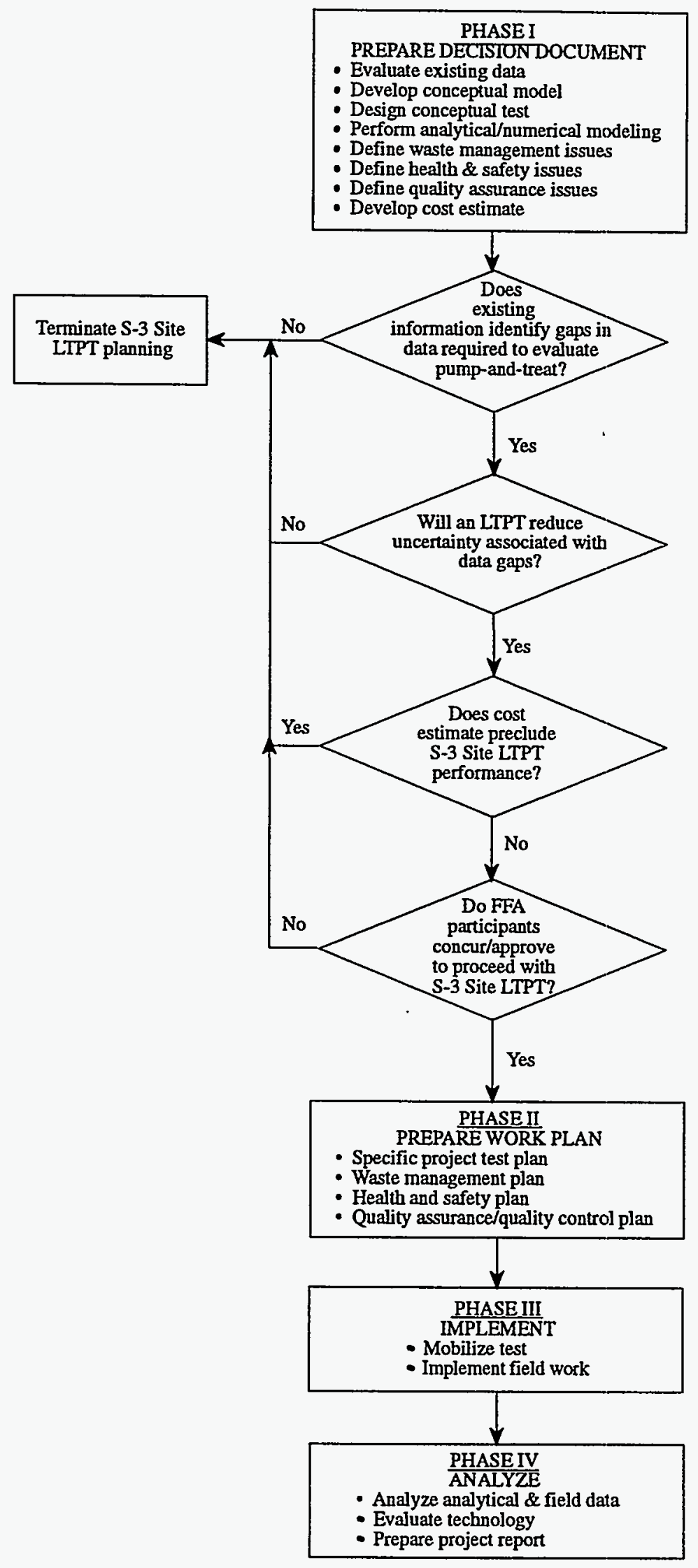

Fig. 1.1. Activity elements and decision points for the S-3 Site LTPT. 
- Phase III Mobilization and field implementation of the LTPT work plan prepared for the project will take place during this phase.

- Phase IV. During this phase, analytical and field data from the LTPT will be analyzed; the effectiveness of pump-and-treat technology as a viable remediation alternative for contaminated groundwater at waste sites overlying the Nolichucky Shale within Bear Creek Valley (including the S-3 Site) will be evaluated; and a final project report will be prepared.

The information gathered during Phase I will be used at the decision point illustrated in Fig. 1.1 to determine whether additional data from an LTPT will be needed to evaluate the effectiveness of pump-and-treat technology to remediate groundwater at the S-3 Site. Phase I includes a series of objectives that must be met to reach this decision point. The following are details of the scope and objectives of Phase I activities:

- Review and evaluate existing data that are presented in pumping, tracer, and groundwater tests; hydrologic and geochemical modeling; and source/hydrogeologic characterization studies that were conducted in Bear Creek Valley.

- Develop a conceptual hydrogeologic and contaminant transport model for transient conditions in the Nolichucky Shale underlying the S-3 Site.

- List physical and chemical data gaps or areas of major uncertainty in the site conceptual model. These data gaps and uncertainties will be described relative to their importance in evaluating the effectiveness of pump-and-treat technology.

- Design a conceptual pumping test for the S-3 Site.

- Define and describe issues related to waste management, health and safety, and quality assurance associated with the conceptual pump-and-treat test design.

- Prepare a preliminary cost estimate for all aspects of the conceptual S-3 Site LTPT.

\subsection{PHASE I LTPT DATA QUALITY OBJECTIVES}

The data quality objective (DQO) process consists of six principal stages; each stage results in an important criterion (or "product") for the study. The six principal stages of the DQO process define the following elements of the study:

- problem to be resolved,

- decision(s) needed to resolve the problem,

- inputs to the decision,

- boundaries of the study,

- decision rule(s), and

- uncertainty constraints.

The DQOs presented below for Phase I are designed to establish the decision criteria necessary to determine whether an S-3 Site LTPT is required. 


\subsubsection{Statement of Problem}

The current site conceptual model for Bear Creek Valley describes the processes that control groundwater flow and contaminant transport in the hydraulic system. However, considerable uncertainty is involved in extending the conceptual model to include the effects of applying stress to the hydraulic system (e.g., pumping water), especially for contaminant transport. A large amount of information exists concerning groundwater flow and contaminant behavior at the S-3 Site. The extent to which these data can be applied to evaluation of a pump-and-treat test has not been assessed. The question to be resolved during Phase $I$ is whether the LTPT needs to be conducted to support evaluation of groundwater pumping and treating as a remedial alternative for the S-3 Site.

\subsubsection{Decisions to be Made}

The decisions to be made during Phase I are identified in Fig. 1.1.

\subsection{Inputs to the Decision}

Figure 1.2 lists the factors that determine whether pump-and-treat technology would be effective for remediating groundwater in the Nolichucky Shale. The decisions identified in Fig. 1.1 will be made on the basis of an evaluation of these factors using the existing information and the initial cost estimate.

\subsubsection{Boundaries of the Study}

The LTPT will concentrate on the western plume in the Nolichucky Shale at the S-3 Site. The eastern plume within the Upper East Fork Poplar Creek (UEFPC) hydrologic regime will not be considered in this evaluation. It is assumed that the Nolichucky Shale in the Bear Creek Valley hydrologic regime behaves hydraulically and chemically the same as it does in the UEFPC regime and that results of this evaluation also would be applicable to that plume. The eastern boundary is therefore located just east of the S-3 Ponds and only incorporates sufficient areas of the UEFPC hydraulic regime to allow evaluation of reasonable boundary conditions. The western boundary is demarcated by the western extent of nitrate contamination within the Nolichucky Shale, $-3000 \mathrm{ft}$ west of the S-3 Site.

The S-3 Site plume in the Nolichucky Shale is bounded to the south by the contact with the Maynardville Limestone; the extent of the S-3 Site plume in the Maynardville is outside the scope of the LTPT. The reasoning behind restricting the scope of this LTPT to the Nolichucky Shale is that the Maynardville Limestone and Nolichucky Shale are hydrologically and geochemically distinct. However, extensive pumping in the Nolichucky Shale could cause water to flow from the Maynardville to the Nolichucky. The northern boundary condition is limited to the extent of the plume.

The upper boundary is located at the water table and is characterized by unconfined conditions. The lower boundary is the region in which contaminated groundwater will not readily flow to a recovery well and is characterized by semiconfined to confined conditions. 


\begin{tabular}{l|l|ll|}
\multicolumn{2}{l}{ Site characteristics } & High $\longrightarrow$ Decreasing probability of success & Low \\
\hline Nature of release & $\begin{array}{l}\text { Small volume } \\
\text { Short duration } \\
\text { Slug release }\end{array}$ & $\begin{array}{l}\text { Large volume } \\
\text { Long duration }\end{array}$ \\
& $\begin{array}{l}\text { Source unit has been } \\
\text { isolated }\end{array}$ & $\begin{array}{l}\text { Source unit } \\
\text { leaching to } \\
\text { groundwater }\end{array}$ \\
\hline
\end{tabular}
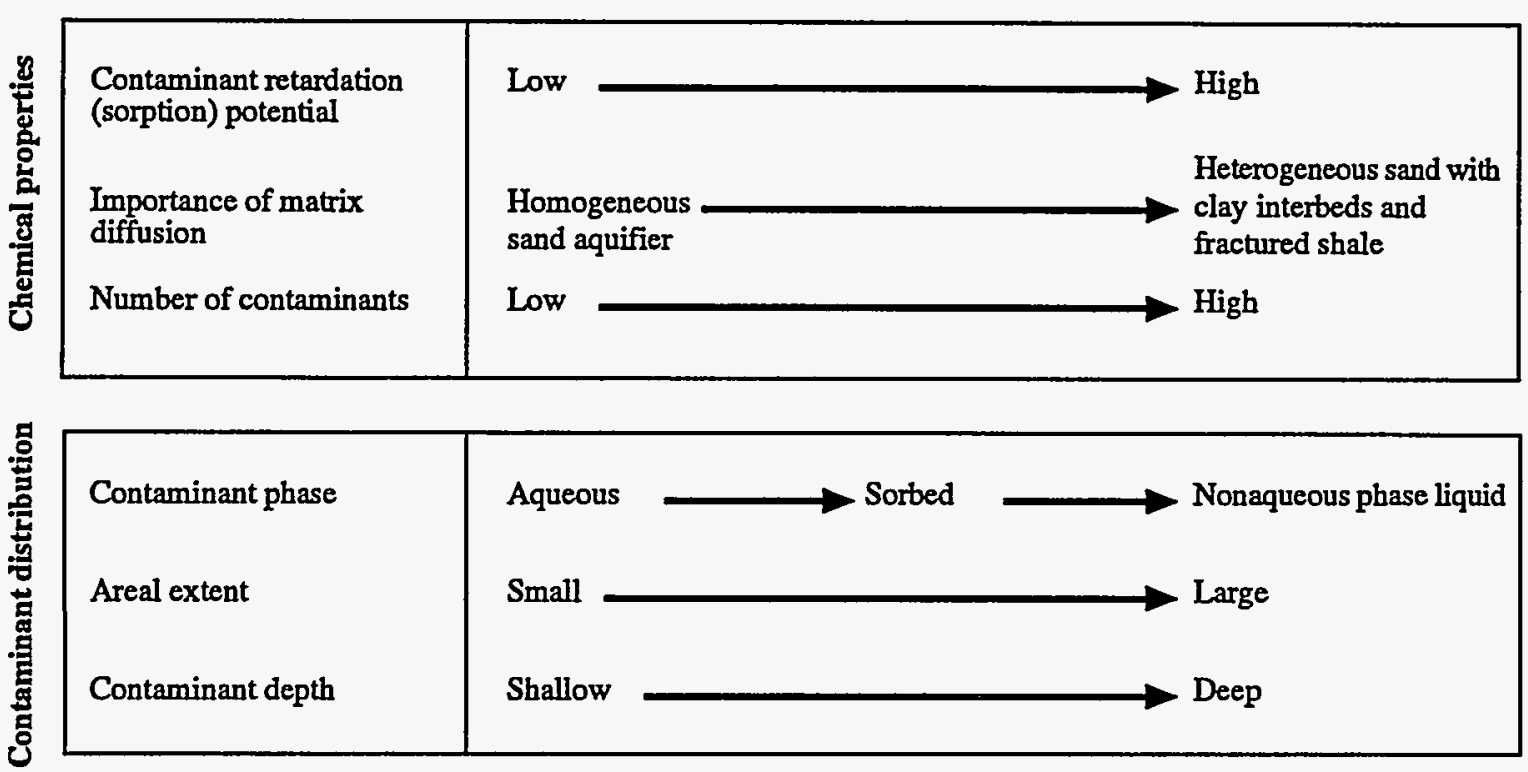

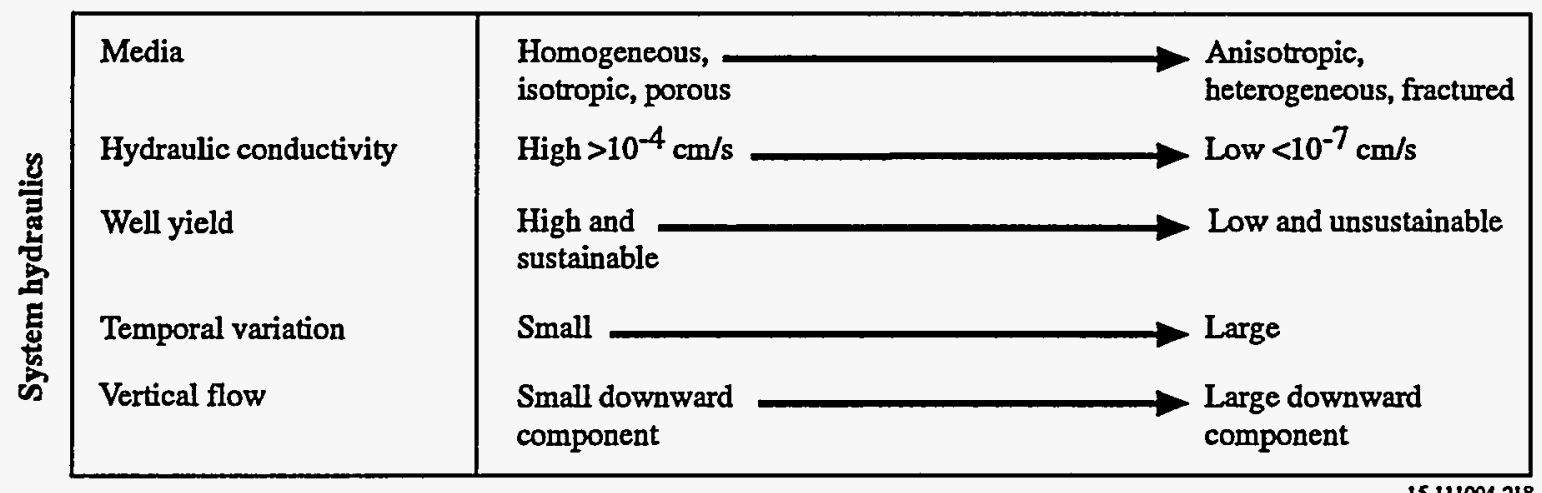

Fig. 1.2. Factors affecting the success of pumping and treating groundwater. Source: EPA 1993, modified. 


\subsubsection{Decision Rules}

The decision rules to be used at the conclusion of Phase I are illustrated in Fig. 1.1. In summary, the primary question to be resolved by $\mathrm{Phase} I$ is whether existing information and data are sufficient to evaluate pump-and-treat technology as a viable option for remediation of groundwater contamination at the S-3 Site or whether an LTPT will provide information that can be used to evaluate pump-and-treat technology. The essential geohydrologic and chemical factors related to evaluation of pump-and-treat technology (Fig 1.2) are used as the criteria for evaluation of the historical information. If some of these factors cannot be adequately described with the existing data, and if funding is available, an S-3 Site LTPT will proceed, provided an LTPT will provide information to resolve those data inadequacies. Alternatively, if all of these factors can be described sufficiently by existing information-or if data derived from the LTPT will not increase the understanding of the system-the S-3 Site LTPT will be terminated.

\subsection{Uncertainty Constraints}

Uncertainty will be associated with each factor listed on Fig. 1.2. For some factors, uncertainty will be relatively low (e.g., nature of release); for other factors, uncertainty may be high (e.g., contaminant retardation potential). 


\section{PREVIOUS STUDIES}

Previous studies regarding the hydrogeologic and geochemical characteristics of the Bear Creek Valley hydrogeologic regime were reviewed from the perspective of providing information to evaluate the objectives of the LTPT as described in Chap. 1. This literature review had two objectives: (1) to identify available hydrogeologic and geochemical data for the Bear Creek Valley hydrogeologic regime relevant to evaluating pump-and-treat groundwater remediation technology and (2) to evaluate these data to determine whether pump-and-treat technology would be an effective alternative for remediating contaminated groundwater in the Nolichucky Shale at the S-3 Site.

\section{HYDRAULIC MEDIA CHARACTERISTICS}

The geology and hydrology of Bear Creek Valley have been extensively characterized during the past decade (e.g., Law Engineering 1983a; Geraghty \& Miller, Inc. 1987a; Dreier et al. 1993). These studies were conducted to satisfy regulatory concerns about various waste units in the valley. Only a few studies have been conducted that specifically address pumping and treating water at the S-3 Site (e.g., Geraghty \& Miller, Inc. 1986 and 1987b). The existing information was evaluated with respect to the criteria established in Chap. 1.

\subsubsection{Geologic Description}

Bear Creek Valley is situated on the Oak Ridge Reservation within the Valley and Ridge physiographic province located in East Tennessee. Rocks underlying the valley are comprised of alternating limestone and shale formations of the Conasauga Group. The valley is bounded by Pine Ridge to the north and Chestnut Ridge to the south. Pine Ridge is underlain by the Rome Formation, and Chestnut Ridge is underlain by the dolostone formations of the Knox Group. A stratigraphic section is presented in Table 2.1. The rocks underlying the valley and adjacent ridges strike northeast/southwest and dip to the southeast at $\sim 45^{\circ}$. The rocks are indurated, and fractures of varying size and distribution occur throughout the rock. The most current detailed information pertaining to the regional geology of the Oak Ridge Reservation can be found in Status Report on the Geology of the Oak Ridge Reservation (Hatcher et al. 1992).

The Conasauga Group, from the youngest formation to the oldest, consists of the Maynardville Limestone, Nolichucky Shale, Maryville Limestone, Rogersville Shale, Rutledge Limestone, and Pumpkin Valley Shale. The S-3 Site and most of the other waste units in the valley overlie the Nolichucky Shale.

In Bear Creek Valley, the Nolichucky Shale ranges in thickness from 442 to $550 \mathrm{ft}$ (King and Haase 1987). Intraclastic limestone, thick fossiliferous limestone, and oolitic limestone interbedded with fissile shale are characteristic of the Nolichucky Shale in the Bear Creek Valley (Foreman et al. 1991). The Nolichucky Shale can be subdivided into four zones based on dominant lithologies: (1) thrombolytic limestone overlying oolitic limestone and lime 
Table 2.1. Stratigraphy of the Y-12 Plant ares (after Solomon et al. 1992)

\begin{tabular}{|c|c|c|c|c|}
\hline Unit & Age & $\begin{array}{l}\text { Thickness } \\
\text { (ft) }\end{array}$ & Lithology & $\begin{array}{l}\text { Hydrologic } \\
\text { unit }\end{array}$ \\
\hline $\begin{array}{l}\text { Knox Group } \\
\text { Mascot Dolomite } \\
\text { Kingsport Formation } \\
\text { Longview Dolomite } \\
\text { Chepultepec Dolomite } \\
\text { Copper Ridge Dolomite }\end{array}$ & $\begin{array}{l}\text { Lower } \\
\text { Ordovician, } \\
\text { Upper } \\
\text { Cambrian }\end{array}$ & $\begin{array}{l}246-394 \\
295-492 \\
130-200 \\
490-700 \\
805-1100\end{array}$ & $\begin{array}{l}\text { Massive dolomite, } \\
\text { siliceous dolomite, } \\
\text { bedded chert, limestone, } \\
\text { some clastics }\end{array}$ & Aquifer \\
\hline $\begin{array}{l}\text { Conasauga Group } \\
\text { Maynardville Limestone }\end{array}$ & $\begin{array}{l}\text { Middle, } \\
\text { Upper } \\
\text { Cambrian }\end{array}$ & $220-453$ & $\begin{array}{l}\text { Dolomitic limestone, } \\
\text { limestone }\end{array}$ & Aquifer \\
\hline $\begin{array}{l}\text { Nolichucky Shale } \\
\text { Maryville Limestone }\end{array}$ & & $\begin{array}{l}442-550 \\
380-400\end{array}$ & $\begin{array}{l}\text { Shale, siltstone, } \\
\text { limestone, calcareous } \\
\text { siltstone and shale, } \\
\text { shaley limestone, } \\
\text { limestone }\end{array}$ & Aquitard \\
\hline $\begin{array}{l}\text { Rogersville Shale } \\
\text { Rutledge Limestone } \\
\text { Pumpkin Valley Shale }\end{array}$ & & $\begin{array}{c}100-120 \\
100-120 \\
320\end{array}$ & & \\
\hline Rome Formation & $\begin{array}{l}\text { Lower } \\
\text { Cambrian }\end{array}$ & $300-410$ & $\begin{array}{l}\text { Shale, siltstone, } \\
\text { sandstone, local } \\
\text { dolomite lenses }\end{array}$ & Aquitard \\
\hline
\end{tabular}

mudstone occur in the uppermost Nolichucky; (2) laminated peloidal packstone, lime mudstone, and shale are more abundant in the upper Nolichucky Shale; (3) oolitic and skeletal packstone and grainstone interbedded with shale are the dominant lithologies in the middle Nolichucky Shale; and (4) intraclastic limestone interbedded with shale and calcareous siltstone are the dominant lithologies in the lower Nolichucky Shale (Foreman et al. 1991). The formation is characterized by massive to thinly bedded, maroon-brown shale and interbedded limestones. The interbedded limestones are lithologically similar to those that occur in the underlying Maryville Formation. Throughout much of the Nolichucky Shale, mudstone/shale and limestone lithologies alternate on a scale from 1 to $3 \mathrm{ft}$, giving the formation a thickly bedded appearance.

Groundwater flows from the Nolichucky Shale to the Maynardville Limestone or to nearby surface streams (Dreier et al. 1993; HSW Environmental Consultants 1991 and 1994b). The Maynardville Limestone stratigraphically overlies the Nolichucky Shale and is located topographically downslope from the shale. Bear Creek occupies the outcrop belt of the Maynardville Limestone and is hydraulically connected to the formation through a series of solutionally enlarged fractures. The unit consists primarily of light-gray to tan, massive to thinly bedded limestone with subordinate amounts of dolostone. The contact between the two formations is transitional, characterized by an increasing percentage of limestone to shale. 


\subsubsection{Hydraulic Characteristics of the Nolichucky Shale}

A conceptual model developed by Solomon et al. (1992) describes the general characteristics of the hydraulic system present on the Oak Ridge Reservation. In general, two broad hydrologic units exist within Bear Creek Valley, a portion of the Knox Aquifer and the Oak Ridge Reservation Aquitard. The Knox Aquifer consists of the Knox Group dolostones and the Maynardville Limestone. The Oak Ridge Reservation Aquitard in Bear Creek Valley is comprised of the remaining formations of the Conasauga Group and the Rome Formation. Groundwater flow in the Knox Aquifer is characterized by high transmissivity and is controlled by solutionally enlarged fractures, whereas flow in the Oak Ridge Reservation aquitard is characterized by low transmissivity and is controlled by fracture flow bedding planes (Solomon et al. 1992).

Solomon et al. (1992) and Moore and Toran (1992) have divided the aquifer and aquitard into the following zones: the stormflow zone, the vadose zone, and the groundwater zone. The groundwater zone is further subdivided into the water table interval, the intermediate interval, the deep interval, and the aquiclude. The distinction between the water table interval and underlying intervals is based on changes in hydraulic parameters and changes in major ion chemistry. Because the stormflow and vadose zones will have negligible effects on pumping the groundwater zone (except as a source of recharge), these zones will not be discussed further.

Solomon et al. (1992) indicate that most of the water in the groundwater zone of the aquitard may be transmitted through an $~ 3$ - to 15 -ft-thick layer of closely spaced connected fractures within the water table interval. This layer approximately corresponds to the weathered rock between the clay-rich regolith above and the less permeable unweathered rock below. Seasonal declines in the water table can nearly drain this interval, resulting in a reduction in the transmissivity and a corresponding decrease in groundwater discharge. Groundwater flow is controlled by fractures. It is hypothesized that the larger well-connected fracture sets are water producing, and the smaller fracture sets together with the rock framework comprise the matrix. Most of the groundwater mass resides within the matrix, and chemical diffusion between the well-connected fractures and the matrix reduces contaminant transport velocities relative to the groundwater flow rate in the well-connected fractures (Solomon et al. 1992).

Specific data concerning large-scale groundwater flow in the intermediate and deep intervals at the S-3 Site were recently submitted by Dreier et al. (1993), who presented detailed hydraulic head measurements from four deep coreholes (GW-132, GW-133, GW-134, and GW-135) (Figs. 2.1 and 2.2). The locations of these coreholes form a transect across Bear Creek Valley in the vicinity of the S-3 Site. Westbay" multiport samplers have been installed in each of the coreholes. These multiport systems allow hydraulic head, hydraulic testing, and water sampling of discrete intervals within the groundwater system. Figure 2.2 is a hydrologic cross section delineated by hydraulic head measurements. The cross section shows topographically driven recharge from adjacent ridges. Discharge patterns appear to be disturbed by the presence of a pressure bulge within the Nolichucky Shale, but they do show convergent flow to the Maynardville Limestone. The pressure bulge may be attributed to pond waste water that infiltrated from the S-3 Site when the ponds were active. Dreier et al. (1993) have identified three contributing factors that explain the pressure bulge: (1) a density contrast between waste water and natural groundwater, (2) chemical reactions that create a favorable pathway to the groundwater system, and, possibly, (3) a superposed relict water 


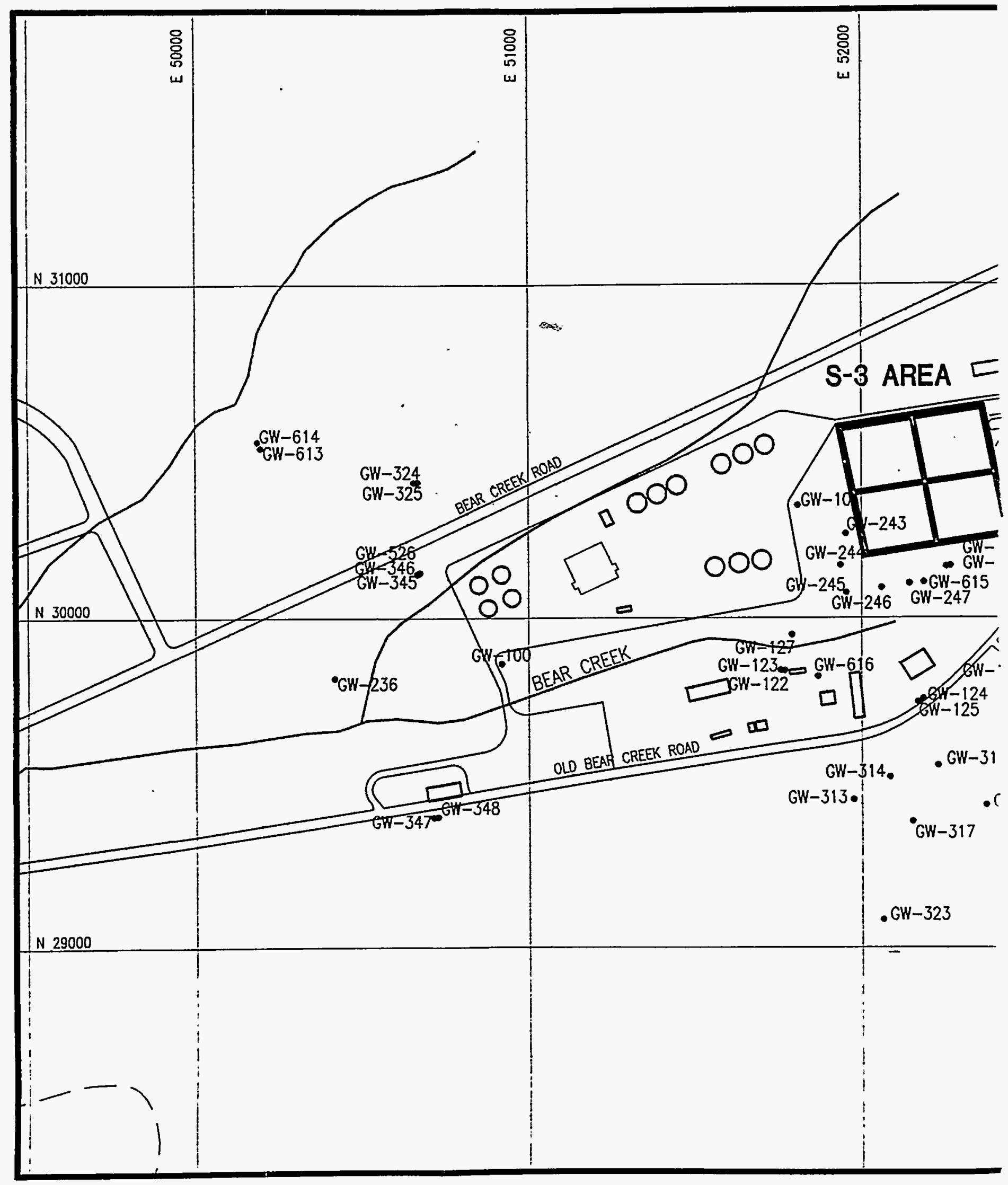

Fig 2.1. Site map showi 


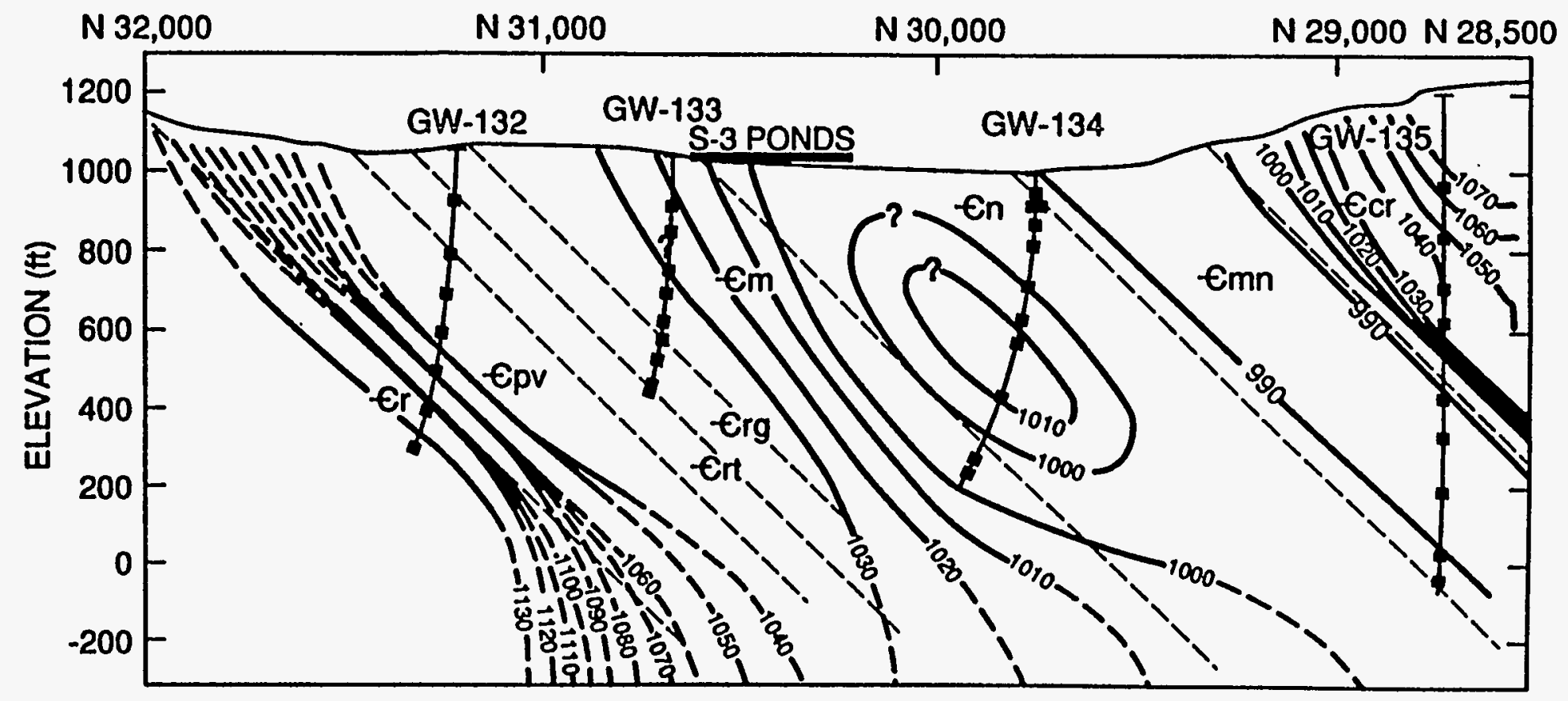

Fig. 2.2. Hydrologic cross section in strike-perpendicular section (after Dreier et al. 1993). $\mathrm{Cr}=$ Rome Formation, $\mathrm{Cpv}=$ Pumpkin Valley Shale, $\mathrm{Crt}=$ Rutledge Limestone, $\mathrm{Crg}=$ Rogersville Shale, $\mathrm{Cm}=$ Maryville Limestone, $\mathrm{Cn}=$ Nolichucky Shale, $\mathrm{Cmn}=$ Maynardville Limestone, $\mathrm{Ccr}=$ Copper Ridge Dolomite. 
mound (the S-3 Ponds) that elevates the fluid pressure in the region surrounding the flow pathway.

\subsection{HYDRAULIC TESTING RESULTS}

Hydraulic tests in Bear Creek Valley have been conducted by a number of researchers over the past decade (Law Engineering, Inc. 1983a; Geraghty \& Miller, Inc. 1986; Lozier et al. 1987; Golder and Associates 1988a and 1988b; King and Haase 1988). Hydraulic testing has consisted of pumping tests, slug tests, packer tests, tracer tests, and, most recently, pulse tests. Only tests that were conducted in the Nolichucky Shale are evaluated in this section. The pulse tests were conducted during a recent remedial investigation, and data have not yet been interpreted. Preliminary results from these data do indicate that a hydraulic response can be observed as far as $400 \mathrm{ft}$ away. Appendix A summarizes the existing hydraulic test information.

\section{Pumping Tests}

Previous pumping tests conducted in the Nolichucky Shale were characterized by low discharge rates and poorly defined elliptical water level drawdown patterns. The transmissivity values calculated from data collected during these tests ranged from $1.49 \mathrm{E}-04$ to $9.29 \mathrm{E}-07 \mathrm{~m}^{2} / \mathrm{s}$. The depths of these tests ranged from the water table to as deep as $100 \mathrm{ft}$. Storage coefficients range on the order of magnitude from $1 \mathrm{E}-03$ to $1 \mathrm{E}-04$. The storage coefficient values are characteristic of semiconfined to confined conditions (Freeze and Cherry 1979). The pumping test data have been analyzed by several techniques, some of which account for fracture flow, anisotropy, and semiconfined conditions. In general, the transmissivity values determined by these techniques agree with the results calculated by the Theis solution. The pumping tests are summarized below.

Geraghty \& Miller, Inc. (1986), conducted a purnping test at the Bear Creek Valley Burial Grounds in January 1985 in Well 1044 for $4.6 \mathrm{~d}$ at an average pumping rate of $4.7 \mathrm{gpm}$. Transmissivity values ranged from $1.7 \mathrm{E}-05$ to $4.4 \mathrm{E}-05 \mathrm{~m}^{2} / \mathrm{s}$, and the average storage coefficient was 5.0E-04. Another short-term $(\sim 4 \mathrm{~h})$ pumping test was conducted at Well GW104 [screen interval 60 to $68 \mathrm{ft}$ below ground surface (bgs)], adjacent to the southern edge of the S-3 Site; the average discharge rate was $8 \mathrm{gpm}$. An average transmissivity value of $4.02 \mathrm{E}-05 \mathrm{~m}^{2} / \mathrm{s}$ was calculated using the Jacob straight-line method. Another pumping test conducted in March 1986 at Well GW-245 (screen interval 44 to $70 \mathrm{ft}$ bgs) (located southwest of the S-3 Site) at a constant rate of $5 \mathrm{gpm}$ had to be discontinued after $61 \mathrm{~h}$ because the water level in the well declined to the top of the intake valve on the pump. The transmissivity values calculated from the test ranged from $1.44 \mathrm{E}-05$ to $1.65 \mathrm{E}-05 \mathrm{~m}^{2} / \mathrm{s}$, and the storativity of the aquifer ranged from $1 \mathrm{E}-04$ to $4 \mathrm{E}-04$.

Figures 2.3 and 2.4 show the locations of monitoring wells and their measured drawdowns at the end of the second S-3 Site test (Geraghty \& Miller, Inc. 1986). During the pumping test, 15 observation wells were used to characterize the aquifer. Eight wells, including the pumping well, were used to monitor hydraulic head in the bedrock, and eight wells were used to monitor hydraulic head in the water table zone. Of the seven observation wells in the 


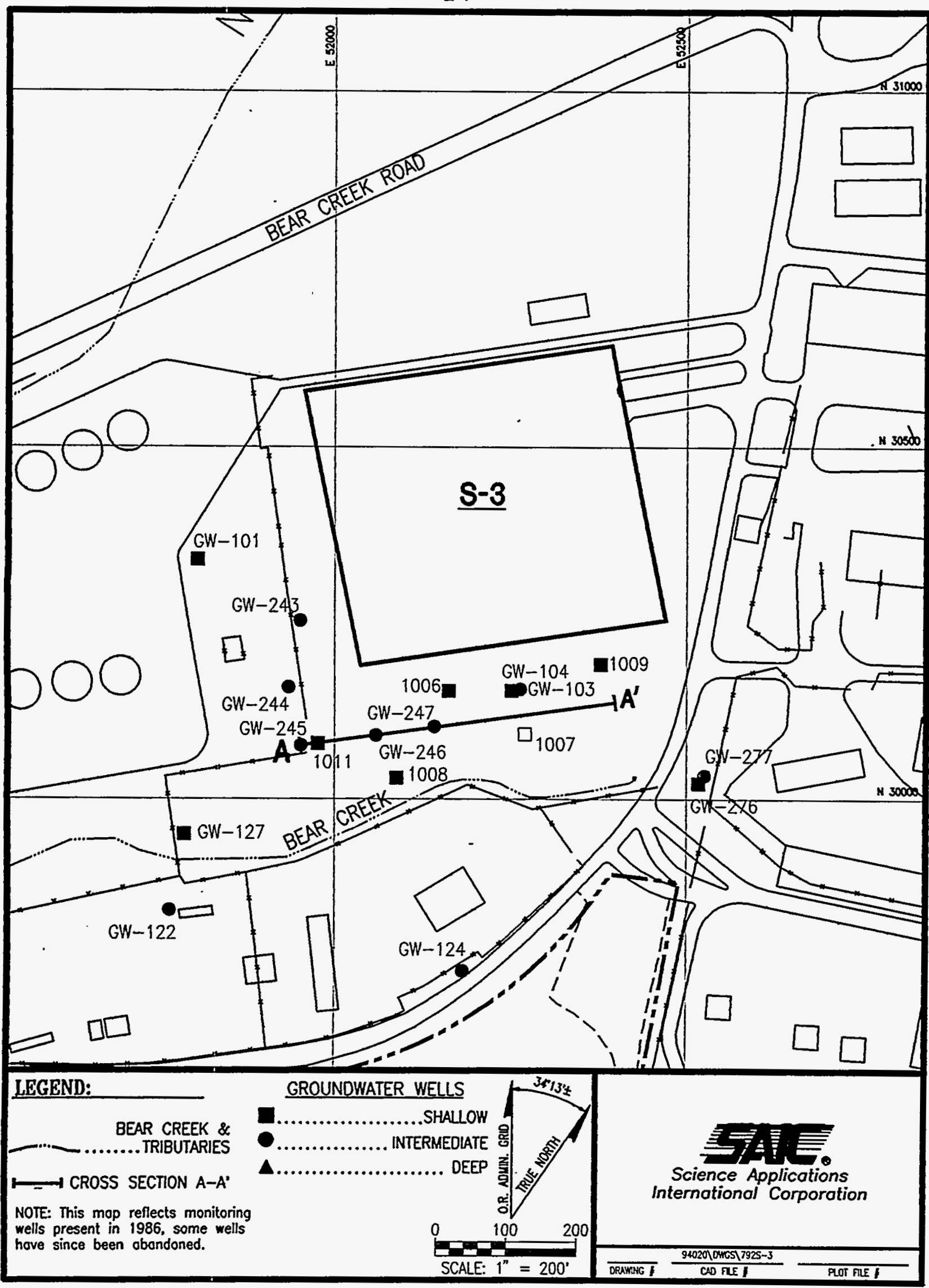

Fig. 23. Locations of the observation wells and the pumping well used during the S-3 Ponds pumping test by Geraghty \& Miller, Inc. (1986). 


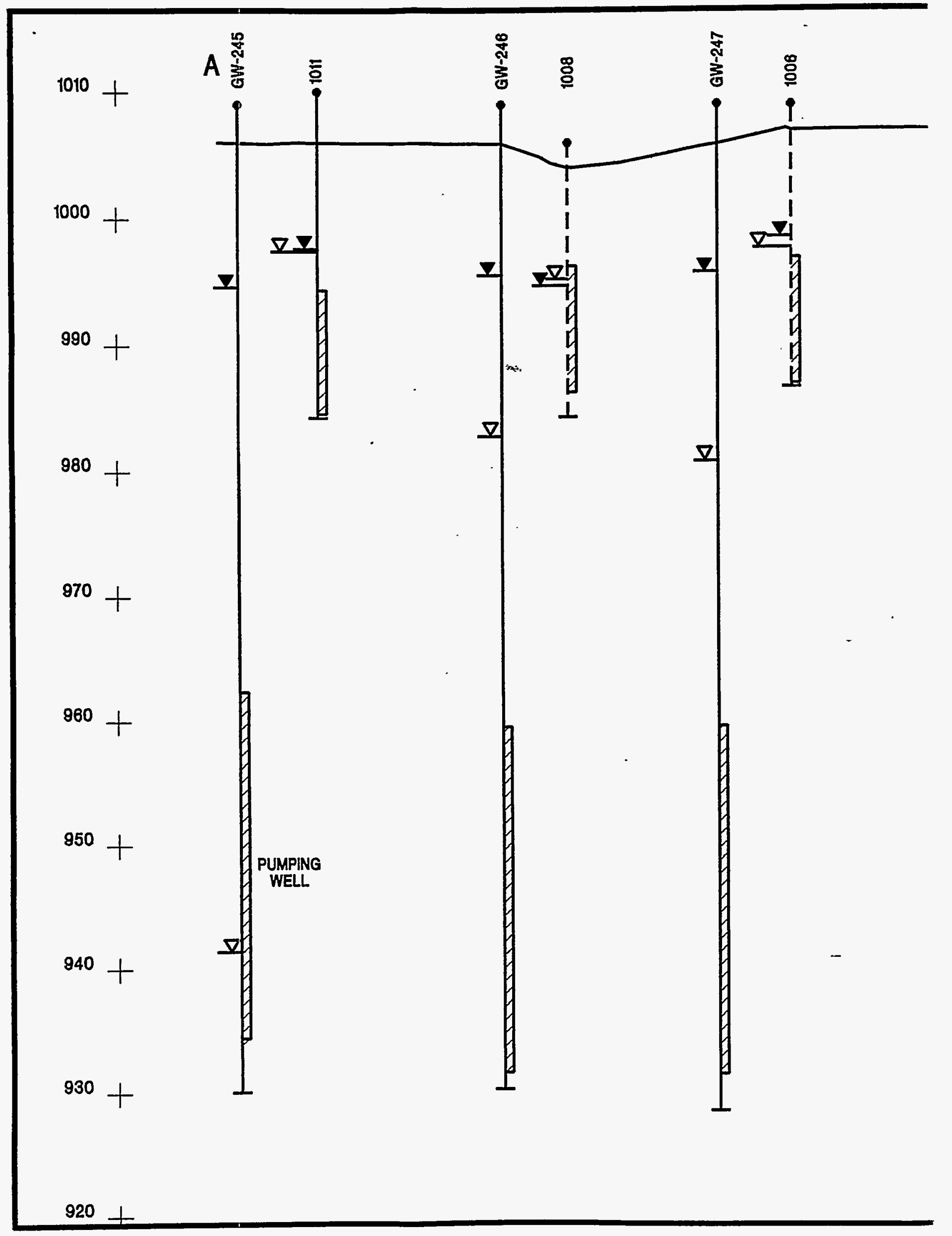

Fig. 2.4. East/west cross section showing conditions before and after 


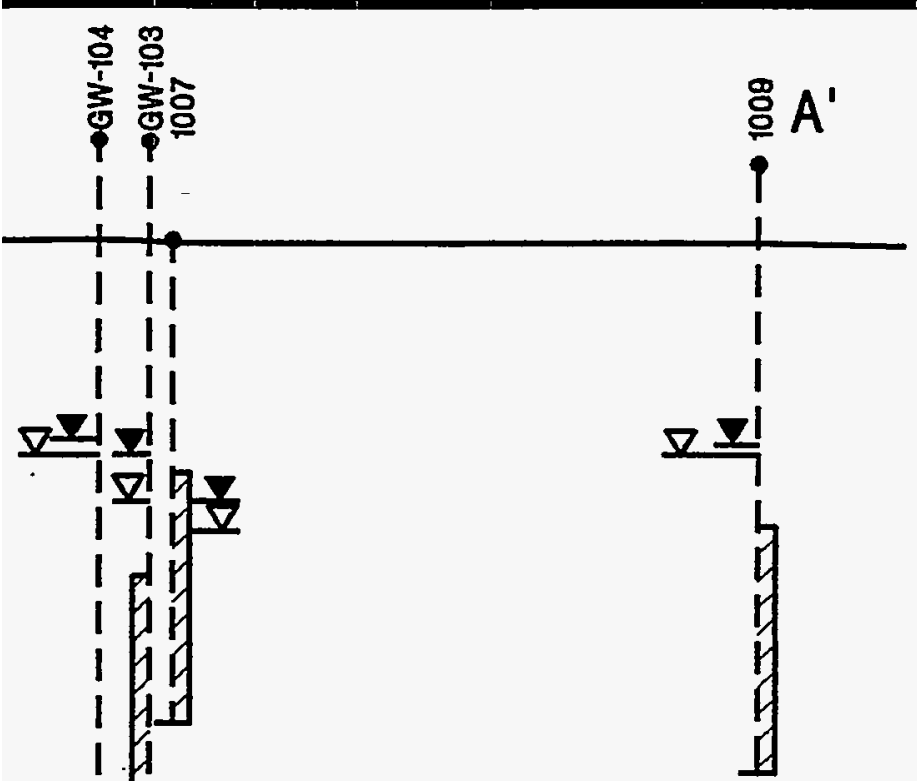

LEGEND:
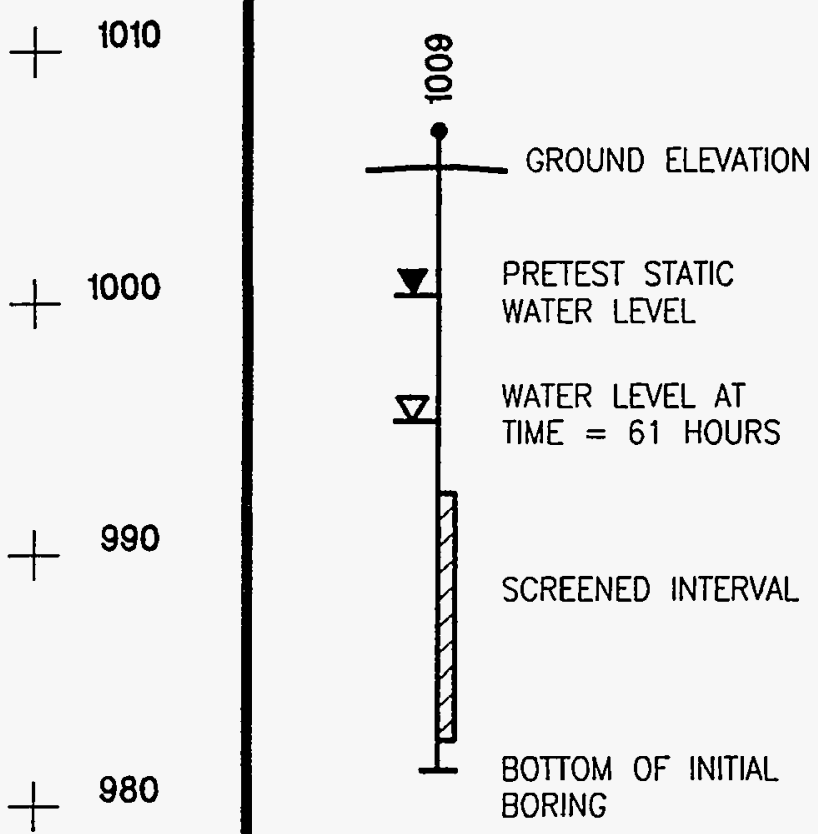

DASHED WELLS ARE PROJECTED ONTO SECTION.
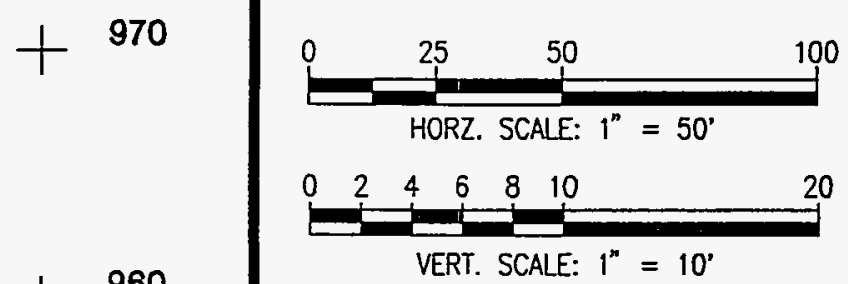

VERT. SCALE: $1^{n}=10^{\circ}$
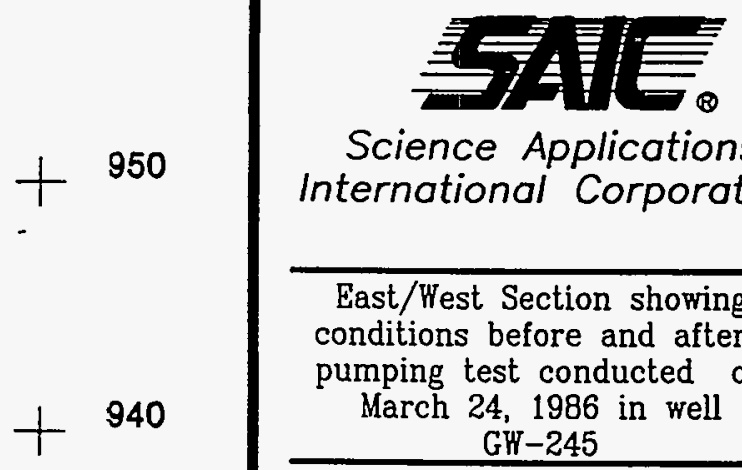

Science Applications International Corporation

East/West Section showing conditions before and after pumping test conducted on March 24, 1986 in well GH -245

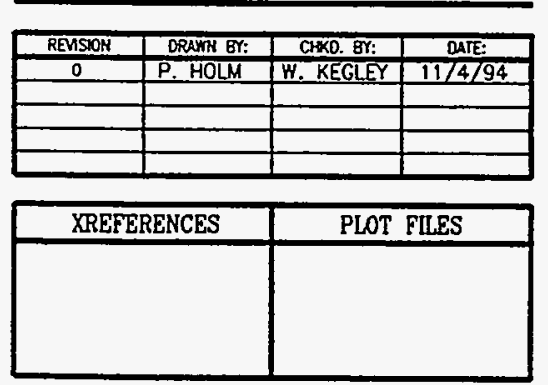


bedrock, only two (GW-246 and GW-247; both wells are screened 47 to $74 \mathrm{ft}$ bgs) showed a response that could be clearly attributed to drawdown as a result of pumping. Drawdown in all of the other bedrock wells wäs $0.51 \mathrm{ft}$ or less. The drawdown in Well GW-247 was also greater than the drawdown in Well GW-246 (Fig. 2.4), indicating that drawdown is not only a function of radius from the pumping well. Drawdown response in the unconsolidated observation wells was low $(<1.8 \mathrm{ft}$ ) and exhibited no relationship to the radius from the pumping well, indicating that hydraulic connection between the water table and the shallow bedrock aquifer is poor and that the media are highly heterogeneous.

Golder Associates, Inc. (1988b), conducted a pumping test in the Nolichucky Shale in western Bear Creek Valley near the intersection of Bear Creek Road and Highway 95. The test included pumping for $24 \mathrm{~h}$ and monitoring water level recovery for the same time period. The following conclusions were drawn from analysis of the pumping test observations and data:

- The Nolichucky Shale appears to behave hydraulically as anisotropic porous media, as indicated by matching of most drawdown data to the Theis curve. However, the drawdown response also indicates the presence of fracture flow, as evidenced by earlytime fracture-influenced drawdown.

- The shale is clearly anisotropic, as evidenced by the results of the GringartenWitherspoon and Papadopulos anisotropic analysis. The results from several analyses indicate a degree of anisotropy of $\sim 13$ for the Nolichucky Shale. The degree of anisotropy in the Nolichucky Shale is illustrated by a distinct nonradial drawdown pattern.

- The direction of maximum transmissivity in the Nolichucky Shale coincides with the strike of the formations. The maximum transmissivity (along strike) of the formation (based on the geometric mean of all results) is on the order of $3.72 \mathrm{E}-04 \mathrm{~m}^{2} / \mathrm{s}$, and minimum transmissivity (oriented perpendicular to the maximum direction) is on the order of $2.79 \mathrm{E}-05 \mathrm{~m}^{2} / \mathrm{s}$.

- The storage coefficient of the Nolichucky Shale is on the order of $10^{-4}$.

\subsubsection{Slug Testing}

Golder Associates, Inc. (1988b) performed 18 rising-head slug tests within wells and coreholes in the Nolichucky Shale located between the Burial Grounds and the S-3 Site. Table A.1 (in Appendix A) presents the results for horizontal hydraulic conductivities calculated from the slug testing performed. The range of horizontal hydraulic conductivities from all intervals within the Nolichucky Shale was found to be $1.16 \mathrm{E}-04$ to $3.53 \mathrm{E}-06 \mathrm{~cm} / \mathrm{s}$, with a geometric mean of $2.04 \mathrm{E}-05 \mathrm{~cm} / \mathrm{s}$.

\subsubsection{Tracer Testing}

Lozier et al. (1987) conducted a 67-h pumping/tracer test in the Nolichucky Shale in Bear Creek Valley near the Burial Grounds during the time period of October 6-9, 1986, to determine values of aquifer transmissivity and their principal directions. The test well was pumped at a constant rate of $2.5 \mathrm{gpm}$, and once steady-state conditions were approximated, brine solution was introduced into three observation wells at three different times. The aquifer responded as an anisotropic porous media. The transmissivity values ranged from 9.29E-05 to $9.29 \mathrm{E}-07 \mathrm{~m}^{2} / \mathrm{s}$, and the average storage coefficient was $\sim 6 \mathrm{E}-04$. 
Salt brine solutions were introduced as slugs in three observation wells at different times. Observed tracer breakthrough curves were matched to a one-dimensional advection dispersion analytical solution to determine values of dispersivity and effective transport porosity. Lozier et al. (1987) summarized the results of the tracer test as follows:

- The dispersivity and effective transport porosity of the shale along strike are $\sim 10 \mathrm{ft}$ and $4.0 \mathrm{E}-03$, respectively.

- The dispersivity and effective transport porosity of the shale perpendicular to strike may be $\sim 10 \mathrm{ft}$ and $8.0 \mathrm{E}-03$, respectively, although additional testing of longer duration is required to confirm these results.

- Comparison of tracer arrival times in the longitudinal (along-strike) direction indicate that dispersivity and effective porosity may be scale dependent.

\subsection{Straddle Packer Testing}

Golder Associates, Inc. (1988b) performed 50 packer tests at various depths and stratigraphic intervals within the Nolichucky Shale in Bear Creek Valley to determine the hydraulic conductivity and hydraulic head of the formation. Table A.2 (in Appendix A) presents the results of the hydraulic conductivity analysis. The geometric mean of all 50 hydraulic conductivity values is $3.04 \mathrm{E}-06 \mathrm{~cm} / \mathrm{s}$.

King and Haase (1988) reported the results from five packer tests (Table A.1) conducted in the Nolichucky Shale from corehole GW-134 located near the S-3 Site. The hydraulic conductivity values were analyzed according to the Horner semilog method. Hydraulic conductivity values $\leq 1 \mathrm{E}-08 \mathrm{~cm} / \mathrm{s}$ were analyzed using a pressure decay test method. Test intervals were selected on the basis of fractures identified from inspection of geologic core and geophysical well logs. The hydraulic conductivity values from these tests had a geometric mean permeability of $5.1 \mathrm{E}-07 \mathrm{~cm} / \mathrm{s}$.

\section{2 .5 Hydraulic Testing Summary}

Review of existing hydraulic information indicates that hydraulic conductivity estimates derived from pumping tests are generally higher than those from slug tests or packer tests. Pumping test values range from $1 \mathrm{E}-03 \mathrm{~cm} / \mathrm{s}$ to $2 \mathrm{E}-04 \mathrm{~cm} / \mathrm{s}$, whereas the geometric mean of the slug tests and packer tests are $2.13 \mathrm{E}-05 \mathrm{~cm} / \mathrm{s}$ and $3.04 \mathrm{E}-06 \mathrm{~cm} / \mathrm{s}$, respectively. No definable pattern was associated with the hydraulic conductivity and depth of the screen zone. The Nolichucky Shale was tested at depths of $<100 \mathrm{ft}$ for the pumping test, $<300 \mathrm{ft}$ for the slug test, and $<1000 \mathrm{ft}$ for the packer test. A logical conclusion for the difference between pumping tests and the small single-borehole tests is that the pumping tests were designed to characterize the fractured portion of the shale; on the other hand, slug tests and packer tests have been performed in the unfractured as well as the fractured portion of the formation. Also, slug tests and packer tests only affect a small area surrounding the well bore. Often this area is slightly damaged as a result of drilling and well installation and produces a lower hydraulic conductivity than the surrounding formation (i.e., skin effect). Slug tests and packer tests generally agree with one another (within an order of magnitude).

Review of the pumping test information indicates that the Nolichucky Shale is anisotropic and heterogeneous and that a zone characterized by confined to semiconfined conditions exists below the water table. The upper limit of this zone is not defined; however, monitoring 
wells that were used as a basis for this observation are screened between 45 to $75 \mathrm{ft}$ bgs. In general, the shale can be modeled successfully as an anisotropic porous medium; however, drawdown patterns from the previous pumping tests indicate small-scale localized heterogeneities that cannot be modeled assuming porous media flow theory. At the S-3 Site, hydraulic connection between the shallow bedrock groundwater system and the water table may be poor, as suggested by the drawdown pattern from the Geraghty \& Miller, Inc. (1986), pumping test and the low storage coefficients obtained from all pumping tests.

\subsection{SOURCE CHARACTERIZATION: S-3 PONDS OPERATIONAL INFORMATION}

The S-3 Ponds were located adjacent to the west end of the Oak Ridge Y-12 Plant and were a part of the former S-3 Waste Management Area. Constructed in 1951, these were four unlined impoundments covering a total area of roughly $400 \times 400 \mathrm{ft}$. The original pond excavations penetrated residual soil and fill materials but, based on the depth of bedrock in wells surrounding the site, did not extend down to the bedrock. Before closure in 1988, the ponds were $\sim 17 \mathrm{ft}$ deep and contained variable amounts of sludge, ranging from 2 to $5 \mathrm{ft}$ thick. The sludge was produced by the neutralization and in situ denitrification of waste water in the ponds. While in operation, each pond had a storage capacity of $\sim 2.5$ million gal. The S-3 Ponds site was closed with a multilayered Resource Conservation and Recovery Act (RCRA) cap, covered with asphalt, and completed as a parking lot (Energy Systems 1987, 1988).

Accurate records of the amounts of waste disposed of in the S-3 Ponds are not available. However, three different sources of waste are known to have been disposed of in the S-3 Ponds:

- liquid wastes generated by Y-12 Plant operations and other facilities, which were deposited between 1951 and 1983;

- sludges generated by the in situ neutralization and biodenitrification of the pond waters carried out in 1983-84 and sludges generated by the treatment of acid raffinate; and

- contaminated sediments from upper Bear Creek placed in the southwestern quadrant of the S-3 Ponds in 1984 prior to capping of the ponds.

The liquid wastes consisted primarily of nitric acid, nitrate waste, pickling and plating wastes, and miscellaneous liquid wastes associated with routine cleaning operations at the Y-12 Plant (e.g., mop water). Other wastes included dilute acid, machine coolants, caustic solutions, and acids with a $\mathrm{pH}$ of $<2.0$. During the mid-1950s, uranyl nitrate solutions containing small amounts of plutonium were discharged into the ponds. Depleted uranium in nitric acid solution and technetium contained in raffinate and condensate also may have been placed in the ponds while they were in operation (Energy Systems 1987 and 1988).

Influent discharge rates varied throughout the period of operation, but the amount of waste was significantly reduced when a nitric acid recovery system became operational in 1976. In 1983, the annual quantity of liquid waste entering the ponds was reported to be $\sim 2.7$ million gal. The annual loss from the ponds caused by evaporation was estimated to be one-half to two-thirds the annual input from direct rainfall, or $\sim 3$ million gal (Geraghty \& 
Miller, Inc. 1987a); the remainder, plus waste input into the ponds, is assumed to have infiltrated to the groundwater.

Water and sludges in the S-3 Ponds have been characterized on several occasions (Jeter 1983; Kimbrough and Turner 1987). Although the pond water chemistry varied from pond to pond and from year to year, in general pond water chemistry remained highly acidic, dominated by the nitrate anion, with extremely high concentrations of the major cationic constituents (calcium, magnesium, potassium, aluminum) and high concentrations of trace metals and radionuclides. The concentrations of contaminants in the pond water, compiled by Geraghty \& Miller, Inc. (1989a), were as follows: average nitrate (as N) concentrations in the northern ponds were $10,425 \mathrm{mg} / \mathrm{L}$ and $6093 \mathrm{mg} / \mathrm{L}$, respectively, before and after 1976; in the southern ponds the values were $9263 \mathrm{mg} / \mathrm{L}$ and $3780 \mathrm{mg} / \mathrm{L}$, respectively, before and after 1976. Groundwater concentrations have been as high as $11,063 \mathrm{mg} / \mathrm{L}$. The average uranium concentrations were $396 \mathrm{mg} / \mathrm{L}$ in the northern ponds and $79 \mathrm{mg} / \mathrm{L}$ in the southern ponds. The concentrations of cadmium were $2 \mathrm{mg} / \mathrm{L}$ in the northern ponds and $0.6 \mathrm{mg} / \mathrm{L}$ in the southern ponds. The concentration of tetrachloroethene also was higher in the northern ponds $(21 \mathrm{mg} / \mathrm{L})$ as compared with that of the southern ponds $(2 \mathrm{mg} / \mathrm{L})$.

The depth of neutralized sludge remaining within the bottom of the former ponds is not known precisely. The top of the pond berm before closure was at an elevation of $1015 \mathrm{ft}$ above mean sea level (Law Engineering Testing Company 1983b), and a pond depth of $17 \mathrm{ft}$ for the ponds is reported by Geraghty \& Miller, Inc. (1987b). The current water table at the $\mathrm{S}-3 \mathrm{Site}$ is at $1007 \mathrm{ft}$ above mean sea level. Given this information, the base of the former ponds is at $\sim 998 \mathrm{ft}$, which is $9 \mathrm{ft}$ below the existing water table. The seasonal fluctuation of the water table is $<9 \mathrm{ft}$, based on data contained in the Groundwater Quality Assessment Reports (GWQARs) issued by the Y-12 Groundwater Protection Program. Thus, waste sludge is in direct contact with groundwater.

\subsection{GEOCHEMICAL ANALYSIS}

For the purpose of this report, discussion of groundwater geochemistry in Bear Creek Valley is contained in the following two sections. In the first section, the major element geochemistry of groundwater in the valley is briefly discussed. The second section contains a more detailed discussion of the contaminant geochemistry and extent of the contaminant plume in groundwater associated with the S-3 Site.

\subsubsection{Groundwater Geochemistry}

Haase (1991) and Toran and Saunders (1992) have identified five water types in Bear Creek Valley groundwater based on major ion chemistry: calcium/magnesium bicarbonate, sodium bicarbonate, calcium/magnesium sulfate, calcium/sodium/magnesium sulfate, and sodium chloride. These water types are generally associated with separate depth intervals and/or geologic formations and are shown in a geochemical cross section of Bear Creek Valley in Fig. 2.5. Haase (1991) and Toran and Saunders (1992) attribute the range of water types to varying degrees of water-rock reactions along differing flow path lengths and, for the sodium-chloride type water, partial flushing of sodium-calcium-chloride brines from deeper portions of the aquifer. 


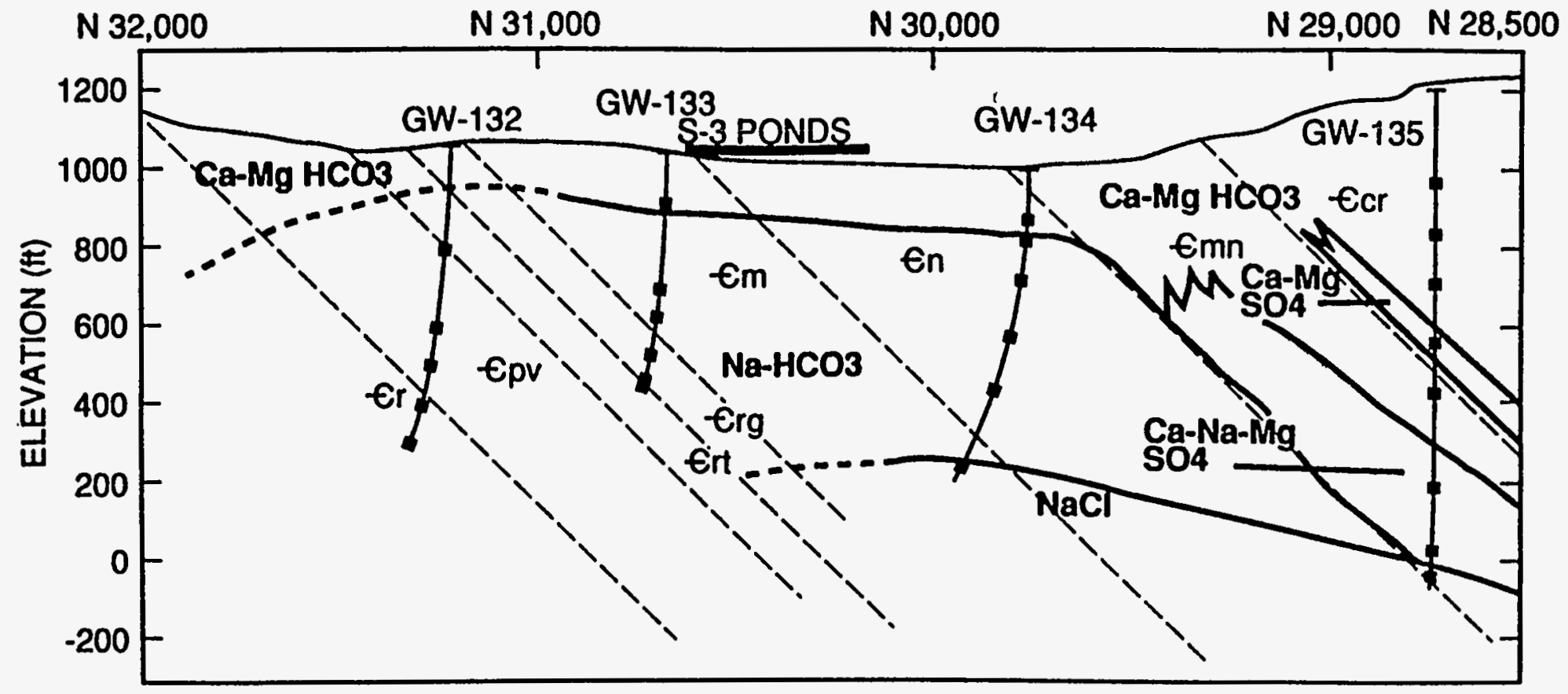

Fig. 2.5. Water-type regimes in strike-perpendicular section (after Dreier et al. 1993). Note that the effects of nitrate contamination in the vicinity of $\mathrm{GW}-134$ have not been incorporated into the diagram. $\mathrm{CR}=$ Rome Formation, $\mathrm{Cpv}=$ Pumpkin Valley Shale, $\mathrm{Crt}=$ Rutledge Limestone, $\mathrm{Crg}=$ Rogersville Shale, $\mathrm{Cm}=$ Maryville Limestone, $\mathrm{Cn}=$ Nolichucky Shale, $\mathrm{Cmn}=$ Maynardville Limestone, $\mathrm{Ccr}=$ Copper Ridge Dolomite. 


\subsubsection{Contaminant Geochemistry}

Groundwater in the vicinity of the S-3 Site is contaminated with a wide range of chemicals consistent with the history of operations at the S-3 Ponds: metals, radionuclides, volatile organic compounds (VOCs), and nitrate. Groundwater chemical data are summarized from the annual GWQARs for the Bear Creek Hydrogeologic Regime (HSW 1991, 1992, 1993, 1994a). The second volume of each GWQAR contains a detailed description of the contaminant distributions in Bear Creek Valley; therefore, only a brief summary of the contaminant distribution is contained in this report. The reader is referred to the GWQAR (especially the annual report for calendar year 1993) for additional details. The interpretation of data used to derive plume maps for this report was also taken from the GWQAR.

The distribution of contaminants in the groundwater plume that has developed in Bear Creek Valley from the S-3 Ponds is strongly dependent on the contaminant geochemistry and the contaminant reactions with aquifer materials. Contaminants that are chemically mobile, such as nitrate, have migrated a long distance from the origin of the plume. Conversely, contaminants that are generally geochemically immobile, or particle-reactive, are only detected in wells close to the site.

Metals. Metals that have most frequently occurred above maximum contaminant levels at the S-3 Site are barium, cadmium, chromium, lead, and mercury; however, the origin of these metals is not necessarily the S-3 Ponds. Detection of these metals is localized to those wells within $\sim 150$ to $450 \mathrm{ft}$ from the S-3 Site.

Radionuclides. Radioactively contaminated groundwater occurs downgradient from the S-3 Site at least as far as the western extent of the Bear Creek Burial Grounds (Figs. 2.6 and 2.7). Radioactive contamination at the S-3 Site likely results from the S-3 Ponds operations. Both alpha and beta emitters are present in groundwater. Radionuclides that have been detected in groundwater at the S-3 Site include the alpha emitters ${ }^{241} \mathrm{Am},{ }^{237} \mathrm{~Np},{ }^{239} \mathrm{Pu}$, ${ }^{228} \mathrm{Ra},{ }^{234} \mathrm{U},{ }^{235} \mathrm{U}$, and ${ }^{238} \mathrm{U}$ and the beta emitters ${ }^{3} \mathrm{H},{ }^{90} \mathrm{Sr}$, and ${ }^{99} \mathrm{Tc}$.

Uranium is the main alpha emitter present in groundwater at the S-3 Site; the other alpha emitters are present in low concentrations. In general, gross alpha counts do not differ greatly in filtered or unfiltered samples. The beta emitters ${ }^{3} \mathrm{H}$ and ${ }^{99} \mathrm{Tc}$ are both geochemically mobile, the former being part of the water molecule and the latter forming an anionic species that tends to react less with mineral surfaces than cationic species. The other beta emitter present is strontium, which has a geochemistry similar to calcium and forms a soluble $\mathrm{Sr}^{2+}$ species when dissolved in water.

Volatile Organics. Various VOCs have been detected in wells in the Nolichucky Shale close to the S-3 Site. However, the distribution of VOCs is highly varied-the suite of organics detected in each well is different, and the concentrations vary greatly between wells. This implies that the plume of organics is very heterogeneous; this effect may have resulted from sporadic disposal of organics in the S-3 Ponds. The principal VOCs detected in groundwater in the Nolichucky Shale at the S-3 Site are acetone, chloroform, and tetrachloroethene. Trichloroethene and dichloroethene also occur as minor contaminants. The 


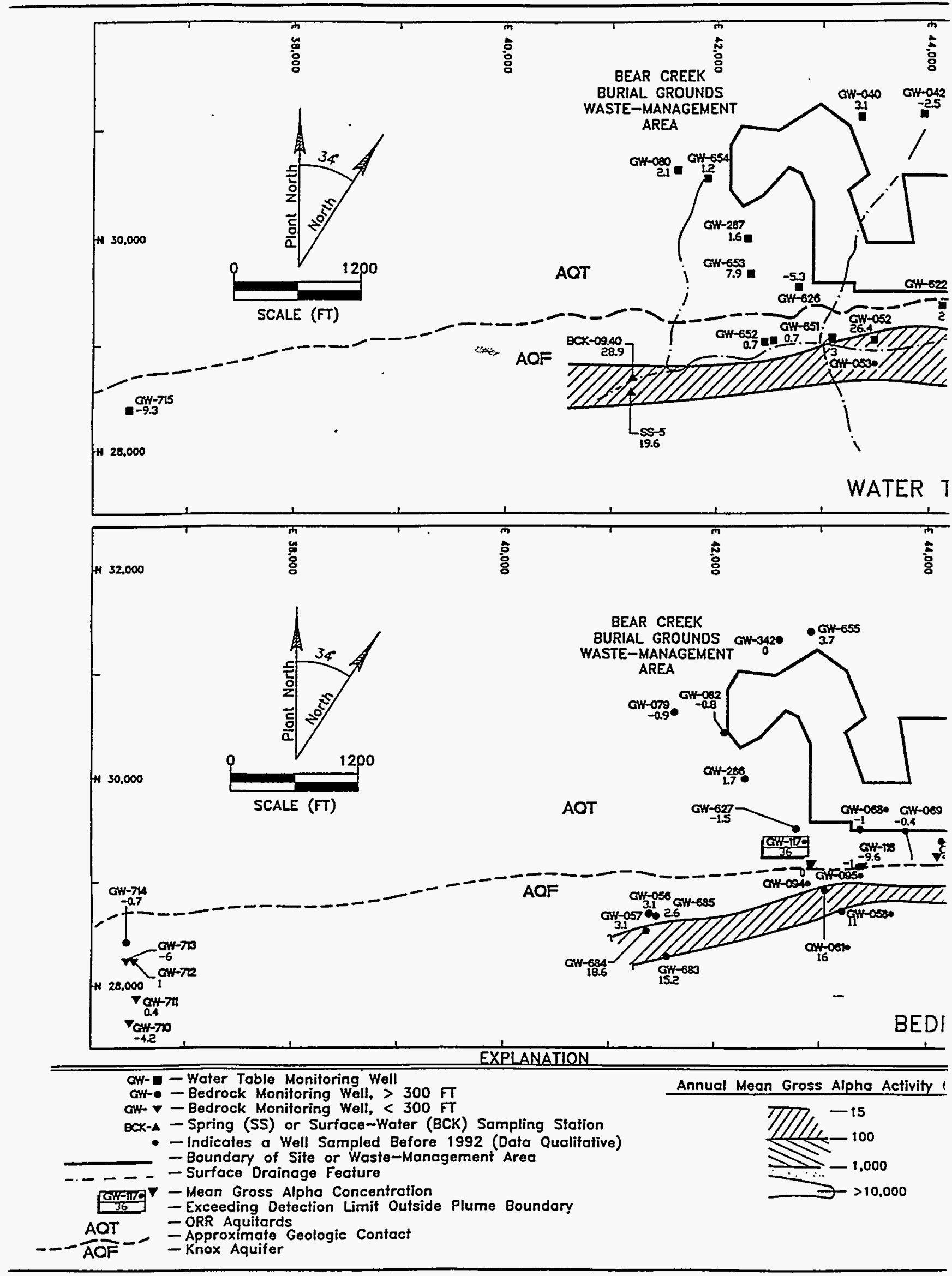

Fig. 2.6. Gross alpha activity in groundwater in 


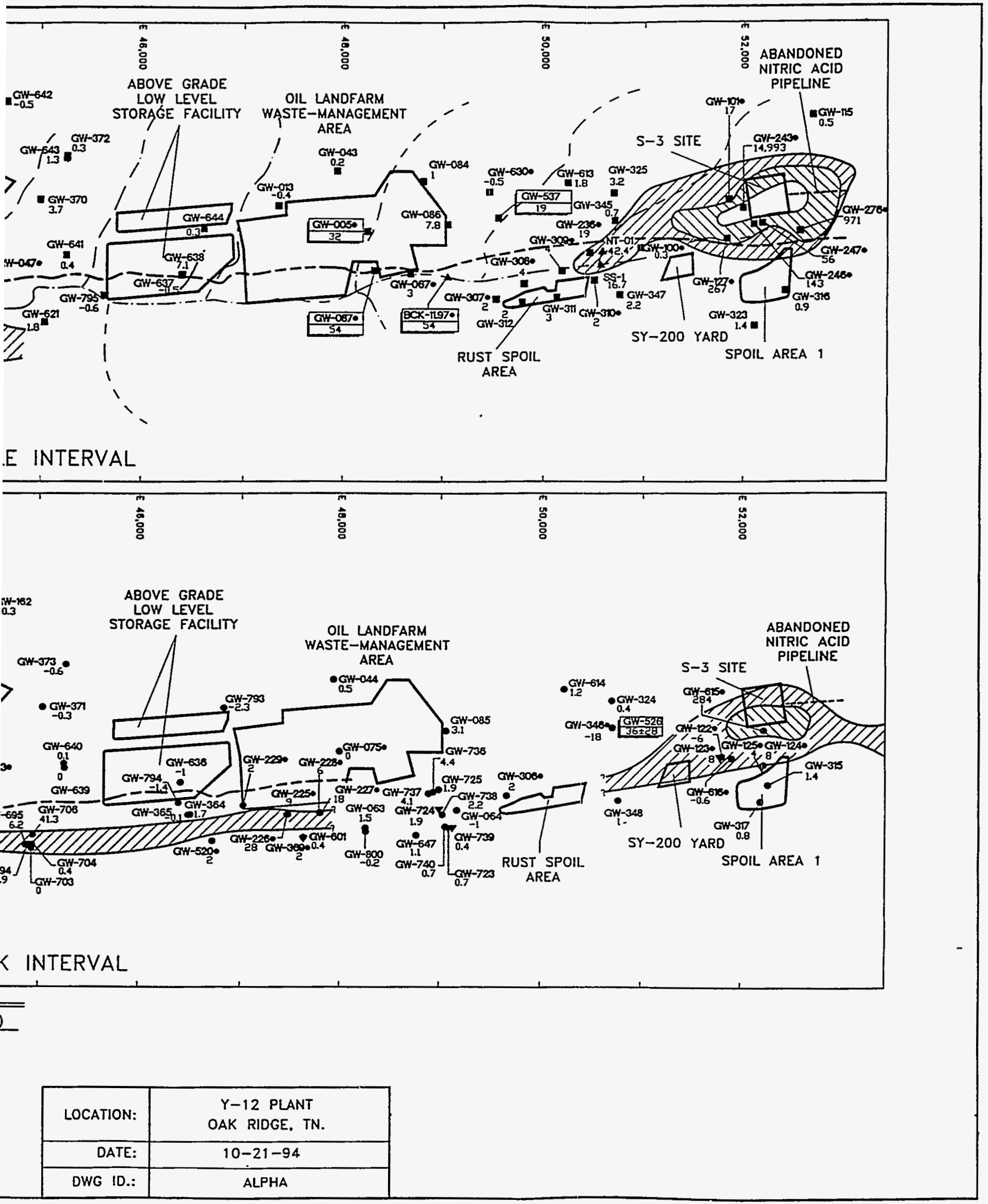

ear Creek hydrogeologic regime. Source: HSW $1994 \mathrm{~b}$. 


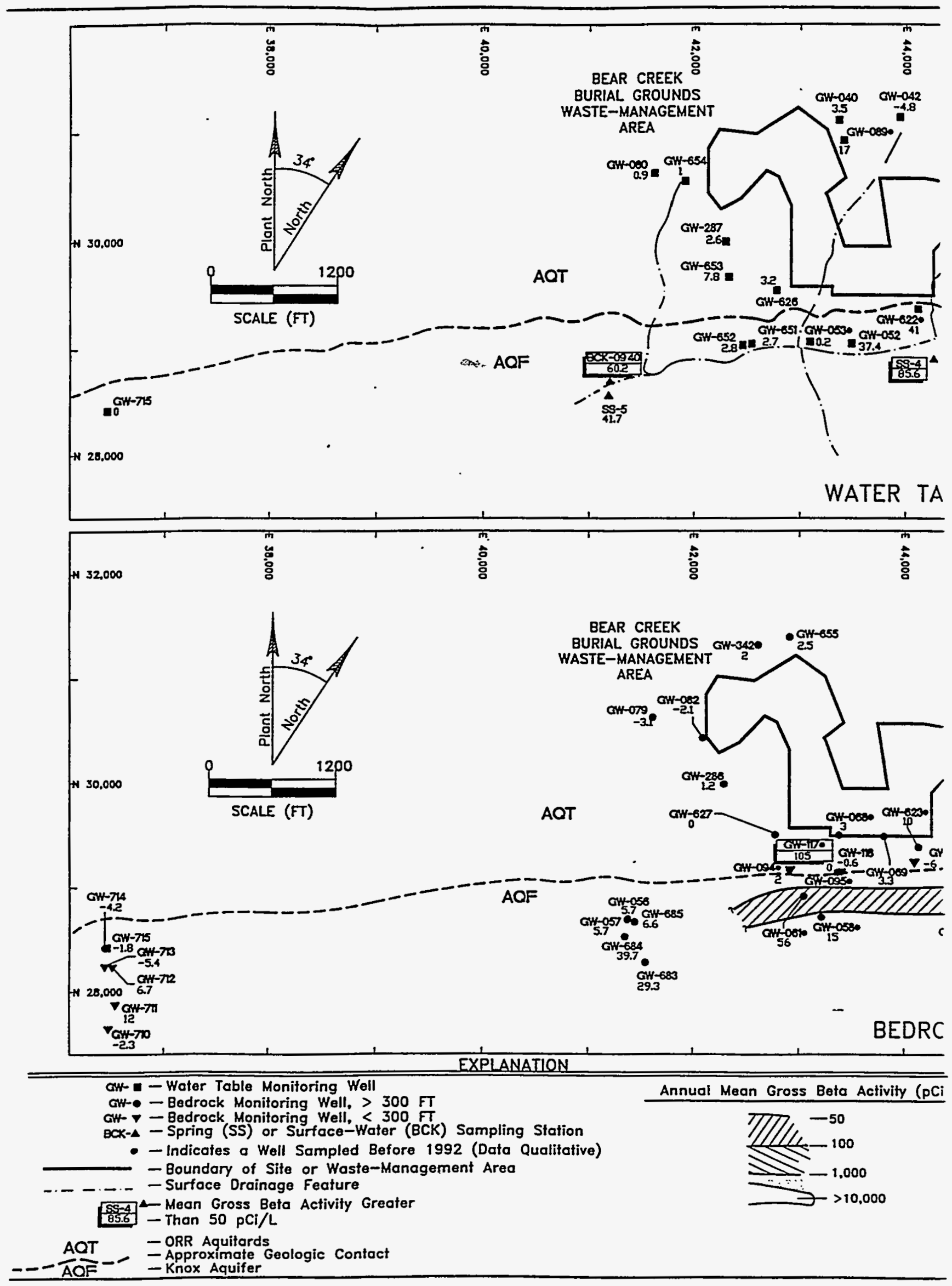

Fig. 2.7. Gross beta activity in groundwater 


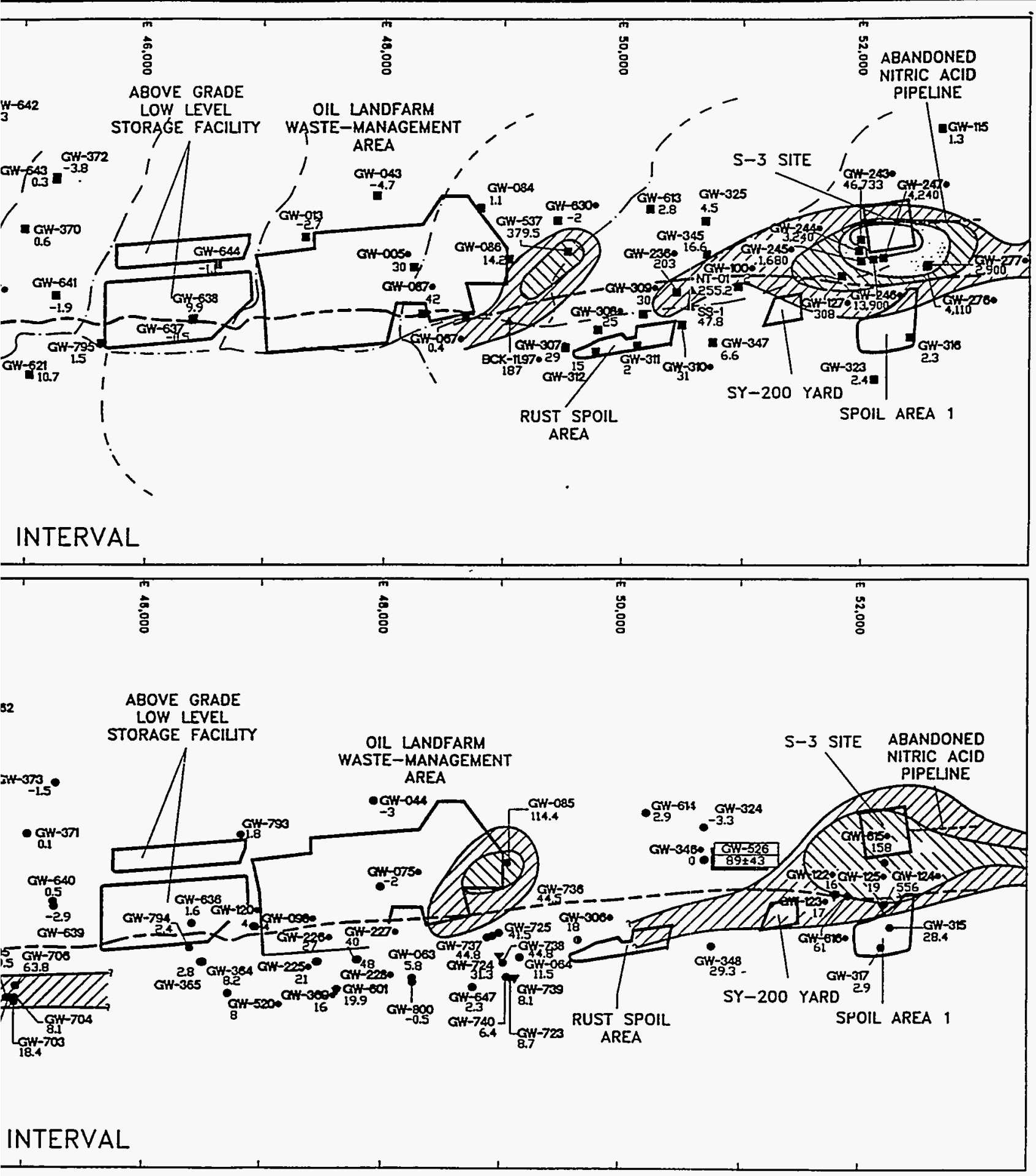

\begin{tabular}{|r|c|}
\hline LOCATION: & $\begin{array}{c}Y-12 \text { PLANT } \\
\text { OAK RIDGE, TN. }\end{array}$ \\
\hline DATE: & $10-21-94$ \\
\hline DWG ID.: & BETA \\
\hline
\end{tabular}

e Bear Creek hydrogeologic regime. Source: HSW $1994 \mathrm{~b}$. 
suite of volatiles in the Maynardville is different from that in the Nolichucky Shale and can be attributed to sources on the Maynardville Limestone (Fig. 2.8).

Nitrate. Nitrate is present in groundwater close to the S-3 Site in concentrations up to $11,000 \mathrm{mg} / \mathrm{L}$ (Fig. 2.9). The nitrate ion is a chemically mobile species that tends not to be retarded by mineral reactions and, as such, can be considered a chemically inert, conservative tracer for the S-3 Site plume.

\subsection{FLOW AND CONTAMINANT TRANSPORT MODELS}

This section provides brief descriptions of the primary groundwater flow and contaminant transport models developed for the Bear Creek Valley S-3 Site.

Geraghty \& Miller, Inc. (1989b) developed a three-dimensional calibrated groundwater flow model for the S-3 Site as well as four contaminant transport models using the Sandia Waste Isolation Flow and Transport (SWIFT) model (Reeves et al. 1985) based on the hydrologic conditions calibrated by the flow model. In 1991, Bailey and Lee (USGS 1991) developed a four-layer groundwater flow model using the Modular Three-Dimensional Finite-Difference Groundwater Flow Model (MODFLOW) (McDonald and Harbaugh 1988) to simulate steady-state groundwater flow in Bear Creek. These models are summarized in Table A.3 (in Appendix A).

Although each of the models developed was calibrated against water level data, the models assume a porous medium and did not examine the role of discrete fractures. It is uncertain whether the Nolichucky Shale can be modeled using a porous media flow code to simulate the gross properties of the fractured system. These models also did not account for the strong vertical permeability and anisotropy that is governed by strike and dip in the shallow bedrock system. In general, the models failed to produce the vertical gradients observed in the field. Significantly, different recharge values were used by the models and were not based on a comprehensive water balance for the Bear Creek Valley. Previous water budgets (Moore 1988; Solomon et al. 1992) indicate that $\sim 90 \%$ of the active subsurface flow occurs through a 3.3- to 6.6-ft-thick stormflow zone; this has not been considered by any of these models. Also, because these are not transient models, they are unable to predict the response of the aquifer to changing conditions (such as those anticipated during an LTPT system).

To design a full-scale pump-and-treat system for the aquifer beneath the S-3 Site, a more rigorous groundwater flow and contaminant transport model capable of modeling transient conditions will be necessary. This model should be capable of modeling flow and transport in fractured rock. Current data gaps limit development of such models, which would require a better understanding of directional hydraulic conductivities to describe the anisotropy of the hydrologic system beneath the S-3 Site, a better interpretation of the fracture distribution in the Nolichucky Shale, and data on aquifer response to long-term pumping and the effects of matrix diffusion on the concentrations of pumped water. 


\section{UNCERTAINTY SUMMARY}

The site characteristics that are necessary for an evaluation of pump-and-treat technology are identified in Fig. 1.2 in Chap. 1. The complexity of these site characteristics can be qualitatively equated to the probability of success with which pump-and-treat technology can be implemented. Table 2.2 summarizes these site characteristics in relation to the S-3 Site. These factors are identified by the U.S. Environmental Protection Agency (EPA) (1993) as characteristics that contribute to the success or failure of a pump-and-treat action. Of the site characteristics identified, ten exhibit features that indicate that pump-and-treat technology most likely would not succeed in remediating groundwater contamination at the S-3 Site. High uncertainty is associated with existing information concerning four of these site characteristics: contaminant retardation potential, matrix diffusion, contaminant phase, and medium.

At the S-3 Site, large volumes of liquid contaminants were emplaced over a 30-year period that ended $\sim 10$ years ago. Currently, sludge from neutralization of the ponds remains in place and may represent a residual source of additional groundwater contamination. The areal extent, volume of contaminated media, and depth of contamination are known with a reasonable amount of certainty.

The site is contaminated with multiple chemicals with different distribution coefficients. Many of the metals are greatly retarded by adsorption; however, nitrate is fairly mobile. Changes in $\mathrm{pH}$ at the site also affect contaminant mobility. Beyond these general statements, little is known about the sorption potential of contaminants at the S-3 Site. The contaminants, particularly the metals, exist in the dissolved phase as well as the solid phase. The transfer of these contaminants from the sorbed to the aqueous phase is not well understood and imparts a high degree of uncertainty to the evaluation of the probability of success for pump-and-treat technology.

Matrix diffusion is an important factor when considering pump-and-treat technology (EPA 1993). The amount of contamination that has been transported into the fine-grained portions of the medium is determined by the amount of time the contaminants have been in the system, the type of contaminants, and the nature of the medium. In the case of the S-3 Site, the contaminants have had 20 to 30 years to diffuse into the matrix, and it is believed that a large mass of contaminants has accumulated in the matrix. The rate at which these contaminants will move out of the matrix and into the fracture zones once the concentration gradient is increased between the fractures and the matrix by pumping is not known. This rate of mass transport is critical in evaluating the pump-and-treat technology. At the S-3 Site, it is possible that matrix diffusion occurs at different scales.

The hydraulic medium is both anisotropic and heterogeneous. An evaluation of existing pumping test data indicates that, at the scale of groundwater extraction, the drawdown in an observation well is not proportional to the radius from the pumping well. Thus, a large degree of uncertainty will be incorporated into pretest and posttest predictive modeling. The hydraulic conductivity of the groundwater system is low, varying from $1.47 \mathrm{E}-03$ to $5.5 \mathrm{E}-08 \mathrm{~cm} / \mathrm{s}$. Temporal fluctuations would not be a contributing factor to the failure of pump-and-treat technology. 


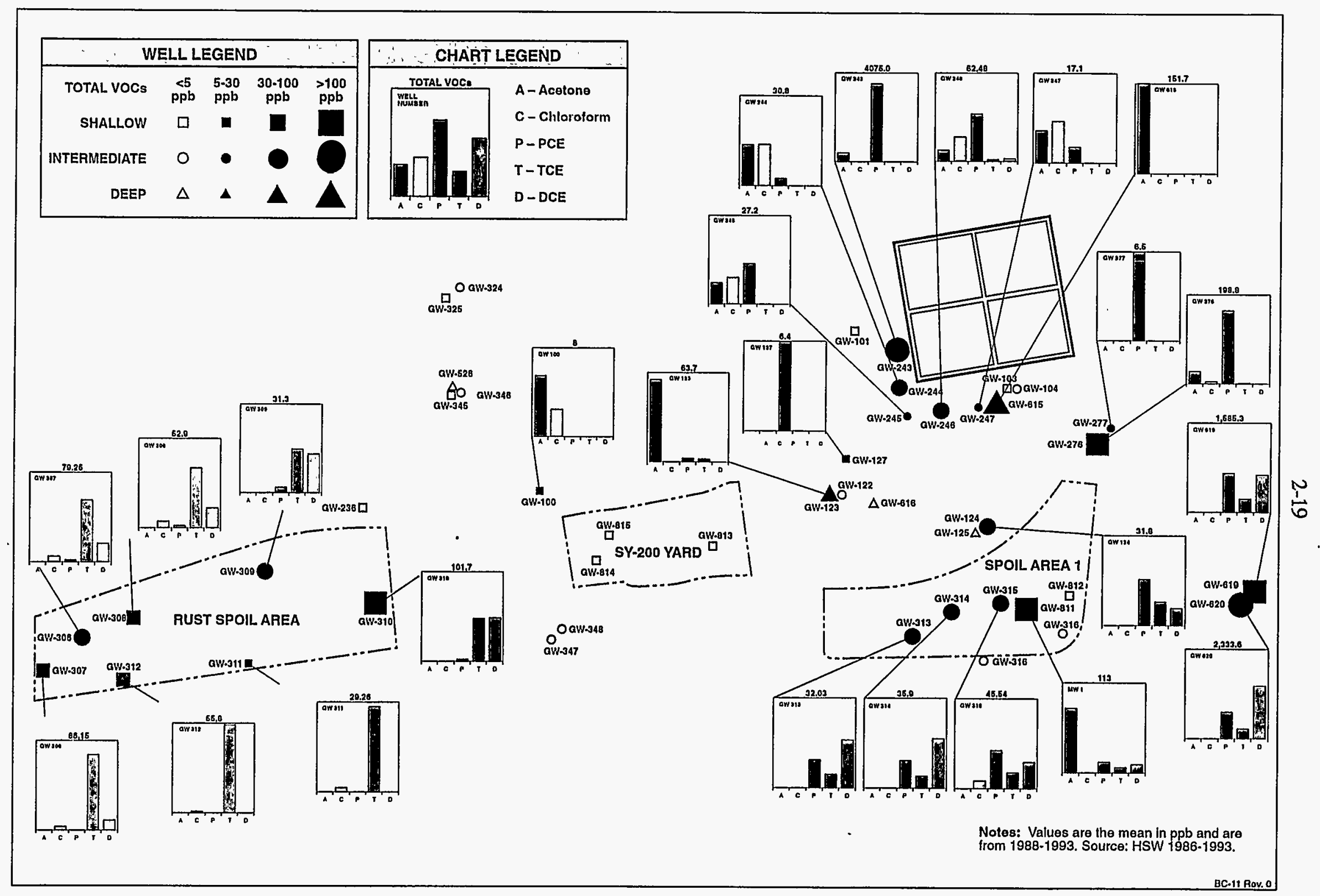

Fig. 2.8. VOCs in groundwater in the vicinity of the S-3 Site. 


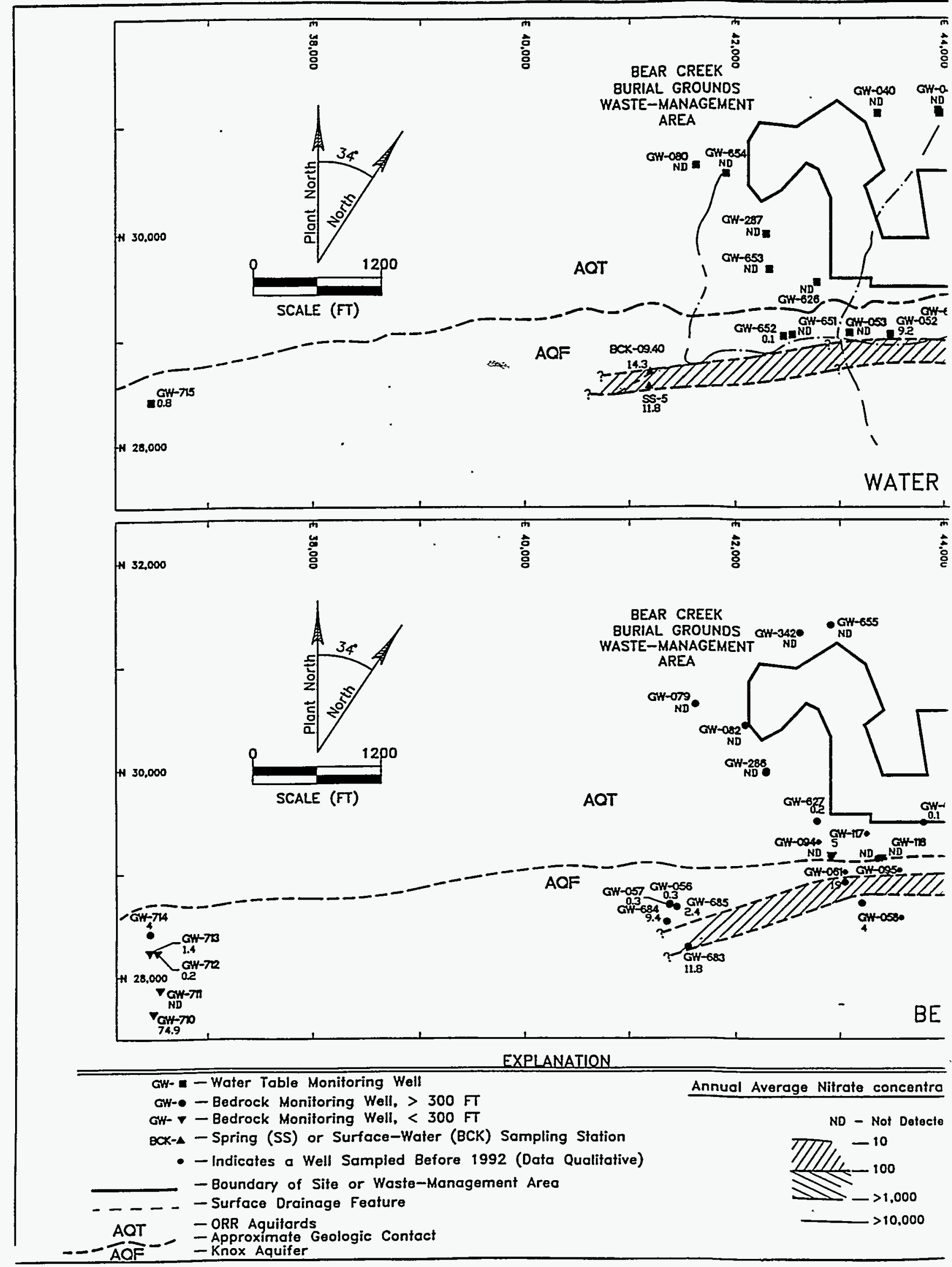

Fig. 29. Nitrate in groundwater : 
Table 2.2. Summary of S-3 Site characteristics

\begin{tabular}{|c|c|c|c|}
\hline Site characteristic & S-3 Site & Uncertainty & Supporting information \\
\hline Nature of release & $\begin{array}{l}\text { Large volume; } \\
\text { long duration }\end{array}$ & Low & The history of the site is well documented. \\
\hline Source control & $\begin{array}{l}\text { Source is leaching } \\
\text { to groundwater }\end{array}$ & Low & $\begin{array}{l}\text { Historical records and current ground- } \\
\text { water level measurements indicate that the } \\
\text { water table is within the source. }\end{array}$ \\
\hline $\begin{array}{l}\text { Contaminant retardation } \\
\text { potential (sorption) }\end{array}$ & Low to high & High & $\begin{array}{l}\text { The site is contaminated with multiple } \\
\text { chemicals that have different distribution } \\
\text { coefficients. }\end{array}$ \\
\hline $\begin{array}{l}\text { Importance of matrix } \\
\text { diffusion }\end{array}$ & Probably high & High & $\begin{array}{l}\text { Beyond general terms, the matrix diffusion } \\
\text { of the site presently is not quantifiable. }\end{array}$ \\
\hline Number of contaminants & High & Low & $\begin{array}{l}\text { Historical records and groundwater } \\
\text { sampling can be used to identify the } \\
\text { contaminants in the plume. }\end{array}$ \\
\hline \multirow[t]{2}{*}{ Contaminant mobility } & Aqueous/sorbed & $\begin{array}{l}\text { Low } \\
\text { (nitrate) }\end{array}$ & Nitrate is relatively mobile. \\
\hline & & $\begin{array}{l}\text { High } \\
\text { (most } \\
\text { metals) }\end{array}$ & $\begin{array}{l}\text { Most of the metals appear to be migrating } \\
\text { very slowly from the S-3 Site. }\end{array}$ \\
\hline Areal extent & $\begin{array}{l}\text { Large }(>1000 \mathrm{ft} \\
\text { from source) }\end{array}$ & Low & $\begin{array}{l}\text { The areal extent of contamination has } \\
\text { been well characterized by the Y-12 } \\
\text { Groundwater Protection Program. }\end{array}$ \\
\hline Contaminant depth & $\operatorname{Deep}(>500 \mathrm{ft})$ & Low & $\begin{array}{l}\text { The contaminant depth at which water } \\
\text { may not be retrievable is } \sim 200 \mathrm{ft} \text {. }\end{array}$ \\
\hline Medium & $\begin{array}{l}\text { Anisotropic, } \\
\text { heterogeneous, } \\
\text { fractured }\end{array}$ & High & $\begin{array}{l}\text { There are sufficient data to indicate that } \\
\text { the medium is complex; however, details } \\
\text { that describe how water throughout the } \\
\text { system will respond to pumping are not } \\
\text { known. }\end{array}$ \\
\hline Hydraulic conductivity & $10^{-3}$ to $10^{-8} \mathrm{~cm} / \mathrm{s}$ & Low & $\begin{array}{l}\text { The hydraulic conductivity of the } \\
\text { Nolichucky Shale has been determined by } \\
\text { pumping, slug, and packer tests. }\end{array}$ \\
\hline Well yield & Low & High & $\begin{array}{l}\text { It is known that well yield will be low; } \\
\text { however, its prolonged sustainability is not } \\
\text { known. }\end{array}$ \\
\hline $\begin{array}{l}\text { Temporal variation of } \\
\text { water table and } \\
\text { hydraulic head }\end{array}$ & Moderate & Low & $\begin{array}{l}\text { The temporal variation of the water table } \\
\text { has been documented by the Y-12 } \\
\text { Groundwater Protection Program. }\end{array}$ \\
\hline Downward vertical flow & Small & High & $\begin{array}{l}\text { The vertical flow component is thought to } \\
\text { be small and in the downward direction } \\
\text { based on hydraulic head measurements } \\
\text { presented in Dreier et al. } 1993 \text {. }\end{array}$ \\
\hline
\end{tabular}


In summary, the parameters that will control contaminant transport from the shale to a recovery well have been identified. These parameters have been established in accordance with guidance presented in EPA 1990 and EPA 1993. A high level of uncertainty is associated with only a few site characteristics; however, of these, only uncertainty associated with the medium could be greatly improved by an LTPT. 


\section{SITE CONCEPTUAL MODEL}

This chapter summarizes a conceptual model of subsurface flow and contaminant transport at the S-3 Site. The conceptual model represents an integration of data, information, and concepts from many technical studies and is intended to describe water flux, water chemistry, and groundwater contamination as they vary in three dimensions and in time at the S-3 Site. The site conceptual model is described here in two components: (1) the sitespecific conceptual hydrological and contaminant transport model for the S-3 Site and (2) a description of how the conceptual model for the S-3 Site responds to the pumping of groundwater.

\subsection{S-3 SITE CONCEPTUAL MODEL_NATURAL GRADIENT CONDITIONS}

In developing the site conceptual model for the S-3 Site, emphasis was placed on the strong stratigraphic and structural controls on groundwater flow. The site conceptual model is a hypothesis based on existing data; as such, some parts of the model are limited by data availability and are speculative. It is the intent of this document to identify as uncertainties those data gaps that need to be resolved so that the groundwater extraction alternative can be evaluated.

The main components of the Oak Ridge Reservation hydrologic conceptual model are described briefly in Sect. 2.1.2 and presented in detail by Solomon et al. (1992). The S-3 Site conceptual model is depicted graphically in Figs. 3.1 and 3.2. The following are brief descriptions of the main components of the S-3 Site conceptual model.

\subsubsection{Geology}

The geology of the Oak Ridge Reservation displays a layer-cake-style stratigraphy with variations on several scales. On the regional scale, limestone- and dolostone-dominated formation groups are interbedded with predominantly clastic groups composed of shales, siltstones, and sandstones. A similar layering style is seen at the outcrop scale, where clastic beds are interlayered with limestone/dolostone beds, as is the case for the Nolichucky Shale (see Sect. 2.1.1). In general, the limestone and dolostone formations provide the best material for transmitting groundwater where solution weathering has occurred. However, where weathering is not extensive, the carbonate beds may be less permeable than the fractured clastic beds. The overall effect of the layer-cake stratigraphy on groundwater flow is that permeability along strike and down dip is considerably greater than permeability across strike.

\subsubsection{Hydrology}

For the S-3 Site conceptual model, the Nolichucky Shale in the Conasauga Group is the formation of most interest; therefore, the conceptual model describes flow in this formation. As mentioned in Sect. 2.1.2, the subsurface flow system can be divided into the stormflow zone; the vadose zone; the groundwater zone, which is subdivided into the water table interval, the intermediate interval, and the deep interval; and the aquiclude (Fig. 3.1). For the 
purposes of the S-3 Site LTPT, the emphasis of the conceptual model is on flow in the saturated zone, and a detailed account of flow in the stormflow zone is not necessary. In addition, the stormflow zone in areas around the S-3 Site has been severely disrupted by pavement and building construction, and it is not likely that natural stormflow exists here. However, rapid recharge and the lateral flow of shallow groundwater to surface water occur in the vadose zone pathway, making this pathway an important one at this site.

\subsubsection{Contaminant Transport}

Contaminant migration rates are strongly influenced by matrix diffusion and geochemical reactions, including ion exchange, sorption, and precipitation/dissolution of mineral phases. The process of matrix diffusion is an important retardation mechanism for most contaminants, regardless of chemistry. This process is emphasized in this report because it is generic to all contaminants and has resulted in a reservoir of contaminants that is held in the matrix or in poorly connected fractures and are slowly released to the active flow system. This process will have considerable control over the effectiveness of pumping and treating groundwater. The concept of matrix diffusion is described in the following paragraph.

Water flow and contaminant migration occur through a series of discrete active flow fractures in the bedrock; little advection occurs through the rock matrix located between these fractures. Contaminants migrate between the matrix and the fractures by way of chemical diffusion that is driven by concentration gradients between the matrix and the fractures. In the Nolichucky Shale, the matrix is probably composed of fine and poorly connected fractures surrounding fragments of almost completely annealed shale that contains little or no porosity and effectively zero permeability (Fig. 3.2). At the S-3 Site, these fine fractures may have been slightly enhanced by dissolution of carbonate minerals. The matrix blocks are contained by isolated, well-connected fracture networks through which the active flow system operates. These fractures have probably been considerably enhanced by dissolution at the S-3 Site. Contaminant migration from the matrix to the active flow fractures is probably by way of a combination of chemical diffusion and advection. There may or may not be chemical diffusion from the rock fragments into fine fractures.

It is possible to observe the combined retardation effect of chemical diffusion and advection from the matrix to the active flow fractures; however, it is unlikely that the effects of these two processes can be isolated. For the purposes of this investigation, the combined effect is termed matrix diffusion.

During operation of the ponds, contaminants generally migrated into the matrix from the active flow system. However, since neutralization and closure of the ponds, the concentrations of contaminants in some portions of the active flow system have diminished and migration has reversed from the matrix to the fractures. This mechanism has resulted in a large body of contaminated water that is contained in the rock matrix of the Nolichucky Shale at the S-3 Site and that slowly releases contaminants to the active flow system. The rate of contaminant diffusion from the matrix to the fractures is controlled by the concentration gradient between the matrix and the fractures and the chemical diffusion rate for the contaminant. Although matrix diffusion is relatively easy to explain conceptually, it is difficult to quantify. Quantifying this process is a major uncertainty in the evaluation of groundwater extraction remedies.

Chemical retardation of contaminants in the aquitard resulting from geochemical reactions is specific to each contaminant and specific to the chemical species in which the 


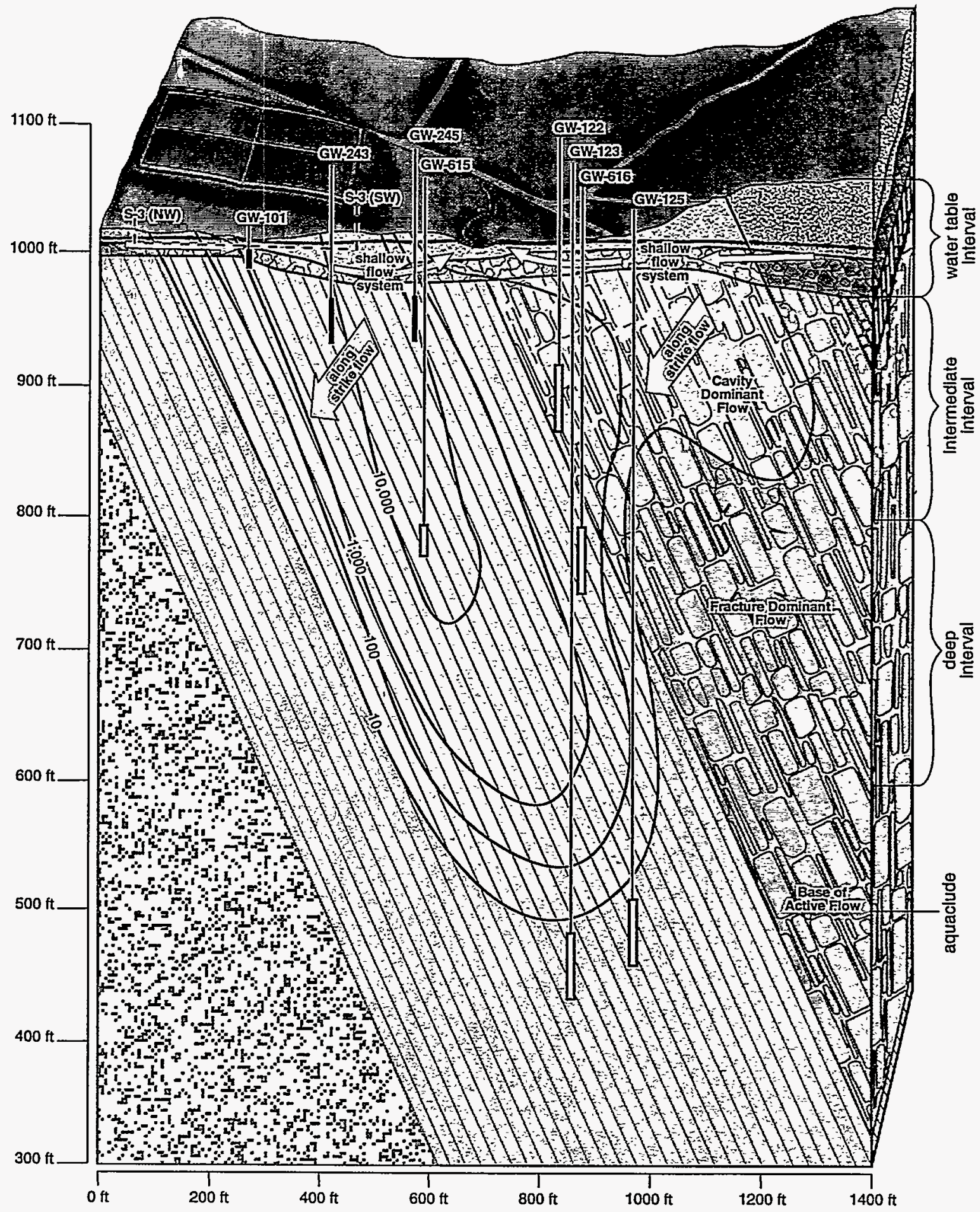

Source: HSW 1993

\begin{tabular}{|c|c|c|c|}
\hline \multicolumn{4}{|c|}{ LEGEND } \\
\hline Open interval & 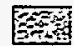 & Regolith & [.7.12 Maryville Limestone \\
\hline Screened Interval & سח & Water Table & A Nolichucky Shale \\
\hline entration (ma/L) & Pres & Weathered Bedrock (Nolichucky) & Maynardville Limestone \\
\hline 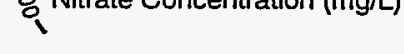 & ags & Weathered Bedrock (Maynardville) & Gy Copper Ridge Limestone \\
\hline
\end{tabular}

Fig. 3.1. S-3 Site conceptual model for groundwater flow and contaminant transport. 


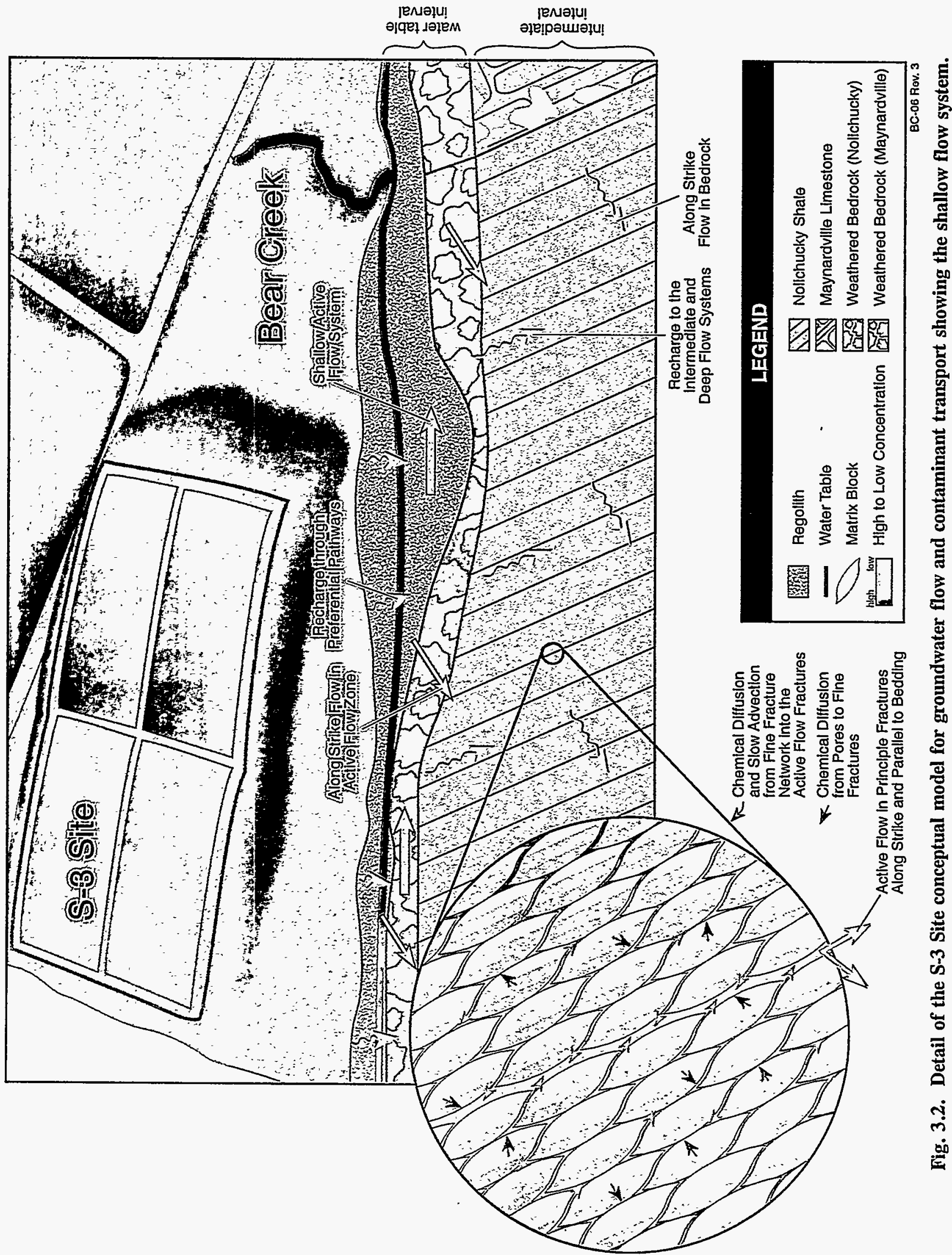


contaminant exists in groundwater at the S-3 Site. For example, the migration rates of tritium, technetium, or nitrate are virtually the same as that of groundwater; strontium and most VOCs are considerably retarded by sorption reactions, but their migration away from the S-3 Site is measurable, whereas the migration of cadmium and some other trace metals through the Nolichucky Shale may be too small to be detected.

\subsubsection{Pathways}

Understanding the structural setting and its controls on fluid flow in the shallow, intermediate, and deep sections of the aquitard is key to developing a model for groundwater movement and contaminant transport in this area. Descriptions of the results of work carried out to date and the general site conceptual model for the Oak Ridge Reservation are contained in Hatcher et al. (1992) and Solomon et al. (1992). The following is a brief description of the flow paths in the S-3 Site conceptual model that probably most influence contaminant migration in the subsurface.

Soil/Bedrock Interface. Because of a marked vertical decrease in permeability in the aquitard formations of the Oak Ridge Reservation, subsurface flow in these formations is predominantly shallow. A convergence of evidence indicates that most water in the groundwater zone of the aquitards is transmitted through a layer of closely spaced, connected fractures near the water table (Solomon et al. 1992).

Observations of water quality in receiving water bodies at the S-3 Site provide some support to the hypothesis of a high transmissivity layer at the bedrock/regolith interface, although they do not by themselves confirm the existence of this layer. The quality of water in the main stem of Bear Creek and in a well located close to the former ponds and screened at the bedrock/regolith interface shows considerable improvement with time since cessation of operations at the S-3 Ponds (Moore and Toran 1992; Shevenell et al. 1994). Conversely, concentrations of contaminants in groundwater in wells screened in the bedrock at the S-3 Site remain relatively constant, and, in some instances, contaminant concentrations have been increasing [e.g., GW-243 (Energy Systems 1993)]. These two apparently conflicting observations can be explained if most of the surface water flow in Bear Creek is the result of groundwater discharge from a shallow flow system of preferential pathways that is flushed continuously, allowing most recharge to bypass the deeper bedrock groundwater flow system. Wells that show declining contaminant concentrations probably intercept this network.

There are important implications for the LTPT of a high-transmissivity layer at the bedrock/regolith interface. Although there is no direct evidence for its existence (such as conductivity measurements or tracer tests), the bedrock/regolith interface high-transmissivity zone is included as an important hypothesis in the S-3 Site conceptual model.

Fracture Control of Flow Paths. Below the water table interval, fracture control becomes dominant in directing flow paths. The Nolichucky Shale probably has little intergranular permeability, but fractures (both parallel to bedding planes and cross-cutting) are present throughout the area. Fracture orientations measured in outcrop on the Oak Ridge Reservation fall into three sets: (1) parallel to and along bedding planes and, thus, parallel to strike; (2) parallel to strike but perpendicular to bedding planes; and (3) perpendicular to strike (Hatcher et al. 1992). Strata-bound fractures are probably the dominant fracture orientation for groundwater flow in bedrock. This set of fractures is generally parallel to bedding planes and is laterally continuous. As a result of this, below the water table interval, 
most groundwater flows either down dip or nearly horizontally along strike and along permeable fracture networks within layers of rock.

At the S-3 Site, the transmissivity of fractures in carbonate-rich beds in the Nolichucky Shale has probably been considerably increased by solution enlargement. Large volumes of acid $(\mathrm{pH}<2)$ have percolated into the subsurface here and have probably created extensive dissolution features in the interbedded carbonate beds in the Nolichucky Shale. The cube law (i.e., doubling a fracture's aperture increases the rate of flow through that fracture by eight times) results in groundwater flow being dominated by the few fractures that have the largest apertures (Domenico and Schwartz 1990); therefore, solution-enlarged fractures in these beds probably provide some of the best along-strike flow paths for groundwater in the vicinity of the S-3 Site.

Developing a more complete understanding of strike-preferential flow paths is an important task for conceptualizing the groundwater flow at the S-3 Site.

\subsection{S-3 SITE CONCEPTUAL MODEL_RESPONSIE TO PUMPING}

The probable hydraulic responses to pumping are shown graphically in Fig. 3.3. This figure illustrates the range in the possible responses which depend on how well the pumping well is connected to the active flow system. Part (a) of Fig. 3.3 shows the hypothetical response to a well that is connected to active flow fractures, and part (b) shows the hypothetical response to a well that is poorly connected. Previous pumping tests have shown that there can be strong response to pumping in the Nolichucky Shale along strike. It follows that the most important pathways for groundwater flow under transient conditions are bedding parallel fractures and that maximum drawdown from the pumping well would be oriented along a plane parallel to bedding. This effect may be enhanced locally by the existence of a few high-transmissivity beds (highly fractured shales or solution-weathered carbonates) that may provide isolated along-strike flow paths as discussed above.

Although the general shape of the cone of depression and the principal groundwater flow pathways can be predicted, the extent of drawdown and the size of the capture zone will depend on the specific location of the screened interval for the pumped well relative to individual fractures or fracture zones. If the well screen intercepts a fracture set, the response depicted in Fig. 3.3(a) would be expected, where the capture zone is extensive along strike and down dip. In this case, it is likely that the pumping well would be able to sustain a $1.5-\mathrm{gpm}$ extraction rate. If the well chosen as the pumping well does not intercept a wellconnected fracture system, the response in Fig. 3.3(b) might be expected, where drawdown is localized to the well and the small extent of the fracture system. In this situation, it is unlikely that a well yield of $1.5 \mathrm{gpm}$ could be maintained for a long time period.

The response to pumping across bedding planes is very poor in most places. The notable exceptions to this are a few across-strike fracture zones that probably exist and that connect the main along-strike flow paths to surface water and to the Maynardville Limestone. The locations of such fracture zones are not known; however, the major fractures may occur in Bear Creek Valley at the locations of cross-strike tributaries to Bear Creek. If a pumping well were located close to an across-strike flow zone, the results of the pumping test would likely vary considerably from those of wells where bedding parallel flow dominates. In addition, the importance of these across-strike zones may increase in time during an LTPT as the capture 

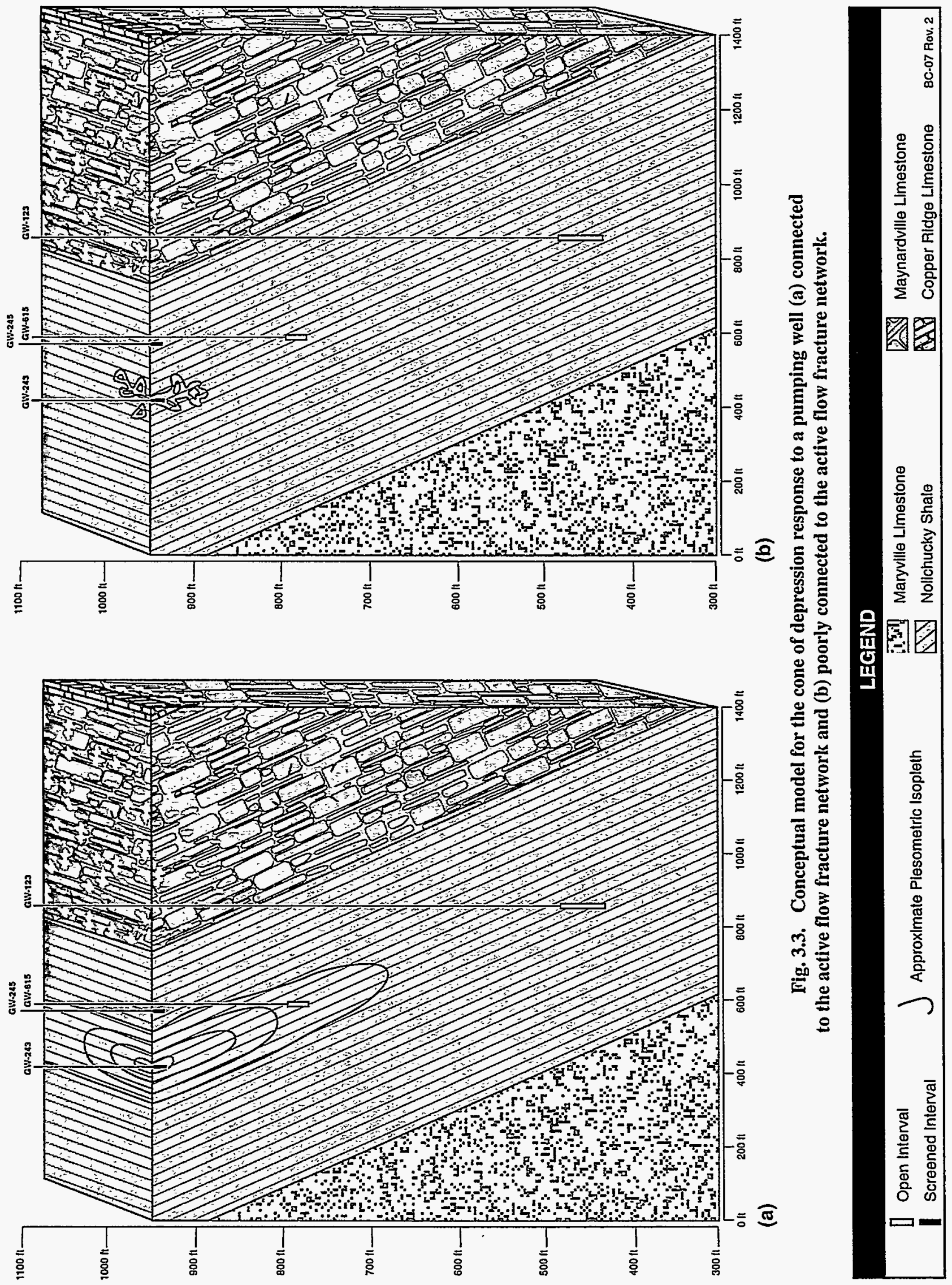

zone for the pumping well increases to incorporate more of the connections to the fracture system.

It is uncertain how the bedrock/regolith interface zone would react to a bedrock pumping well. Assuming that the drawdown created by a pumping well extends upward along the orientation of the bedding planes to the bedrock/regolith interface, it is most likely that the rate of recharge into the bedrock from the regolith would increase at the intersection of the bedding plane and the bedrock/regolith interface. The high transmissivity of the water table zone would result in a broader and more isotropic cone of depression in the regolith.

The major uncertainty associated with the LTPT is the probable geochemical response of the aquifer to pumping. Pumping under the situation depicted in Fig. 3.3(a) would create a rapid decrease in the concentration of conservative contaminants, such as nitrate, as contaminated water in the fractures was drawn into the well and the fractures were flushed with less-contaminated water from the shallow active flow system. Under this scenario, the decrease in concentration is followed by a leveling off of the concentration to an almost constant value with time. This is the result of less-contaminated water that is drawn into the fracture system being contaminated from the matrix by matrix diffusion or by slow drainage of contaminated groundwater from the matrix block. A nonconservative tracer that is affected by mineral adsorption would probably show a decrease in concentration with time; however, the decrease would probably be more pronounced due to the retardation effect of the sorption reaction.

Pumping under the situation depicted in Fig. 3.3(b) may create a completely different geochemical response. Under this situation, the water being pumped from the well is water that has drained from the matrix. Concentrations will probably not decrease in time but will probably remain elevated and may increase depending on the local distribution of contaminants, assuming discharge from the well can be maintained long enough to establish any trend. 


\section{PUMPING TEST DESIGN}

A pumping test conceptual design has been created based on the existing information and the conceptual model described in Chaps. 2 and 3. Several assumptions have been made concerning the type of test that will be conducted to facilitate the conceptual design and allow a reasonable cost estimate to be developed. The test objectives, assumptions, and design are discussed below.

\subsection{TEST OBJECTIVES}

The pumping test will be conducted to achieve the following objectives:

- determine the long-term sustainable well yield within the fractured shale,

- quantify the maximum achievable contaminant mass recovery rate, and

- determine the zone of probable capture of contaminants.

\subsection{DESIGN ASSUMPTIONS}

1. A single-well test is assumed for the conceptual design. The pumping test is conducted in the Nolichucky Shale. Because the fracture network is known to be nonhomogeneous, there is a high degree of uncertainty in interpreting the drawdown response from multiple pumping wells.

2. The area to be tested should be close to the S-3 Site in the area of highest contamination. Disposal activities at the S-3 Site probably have considerably altered the subsurface; therefore, to be representative of conditions at the S-3 Site, the best option is to carry out the pumping test at the S-3 Site.

3. The pumping test is carried out using a well screened in the bedrock. Most of the contamination is located in bedrock and not in the regolith.

4. According to information from a previous pumping test (Geraghty \& Miller, Inc. 1986), the fractured bedrock system cannot be pumped at $>5 \mathrm{gpm}$ and sustain a well yield.

5. The medium is known to be fractured, anisotropic, and heterogeneous. These conditions make quantitative interpretation of the results complicated. The interconnectivity of fracture sets controls the zone of capture. The details of these fracture sets are an uncertainty associated with evaluation of pump-and-treat technology as applied to the Nolichucky Shale at the S-3 Site.

6. The anticipated drawdown is somewhere between the two extremes depicted in Fig. 3.3. 
7. The pumping is carried out using the existing well network. No new wells will be constructed.

\subsection{CAPTURE ZONE MODELING}

A simple analytical approach based on Hantush and Thomas (1966) for an anisotropic confined aquifer was used to develop an estimate of the likely zone of influence (capture zone) for a single well pumping at $1.5 \mathrm{gpm}$. This capture zone estimate will be used in the conceptual design as an order of magnitude guideline to the likely extent of the capture zone. The hydraulic parameters used for this calculation are presented in Table 4.1.

Table 4.1. Parameter values used in the pumping test design

\begin{tabular}{lll}
\hline \multicolumn{1}{c}{ Parameter } & Value & \multicolumn{1}{c}{ Unit } \\
\hline Pumping rate, $\mathrm{Q}$ & $8.18 \mathrm{E}+00$ & cubic meters/day \\
Storage coefficient, $\mathrm{S}$ & $4.00 \mathrm{E}-04$ & unitless \\
Hydraulic conductivity across strike, $\mathrm{K}_{\mathrm{x}}$ & $2.1 .2 \mathrm{E}-03$ & meters/day \\
Hydraulic conductivity along strike, $\mathrm{K}_{\mathrm{y}}$ & $2.75 \mathrm{E}-02$ & meters/day \\
Aquifer thickness, $\mathrm{h}$ & $5.20 \mathrm{E}+01$ & meters \\
Pumping time, $\mathrm{T}_{\mathrm{f}}$ & $3.00 \mathrm{E}+01$ & days \\
Transmissivity in $\mathrm{X}, \mathrm{T}_{\mathrm{x}}$ & $1.10 \mathrm{E}-01$ & square meters/day \\
Transmissivity in $\mathrm{Y}, \mathrm{T}_{\mathrm{y}}$ & $1.43 \mathrm{E}+00$ & square meters/day \\
Transmissivity in $\mathrm{XY}, \mathrm{T}_{\mathrm{e}}$ & $3.97 \mathrm{E}-01$ & square meters/day \\
\hline
\end{tabular}

The modeling is based on the following assumptions developed in the site conceptual model:

1. The aquifer is confined.

2. The aquifer has infinite areal extent.

3. The aquifer is homogeneous and anisotropic on the horizontal plane and of uniform thickness over the area influenced by the test. Although this is a poor assumption, there are no straightforward methods that could be used to model the S-3 Site.

4. Before pumping, the piezometric surface is horizontal over the area that will be influenced by the test.

5. The aquifer is pumped at a constant discharge rate.

6. The well penetrates the entire thickness of the aquifer and thus receives water by horizontal flow.

7. The water removed from storage is discharged instantaneously with decline of head. 
8. The diameter of the well is small compared with the radius of influence of the test, so that the effects of well-bore storage can be neglected.

Figure 4.1 shows projected drawdown curves at the end of $1 \mathrm{~d}$ of pumping at the rate of $1.5 \mathrm{gpm}$; Fig. 4.2 shows the estimated drawdown after $10 \mathrm{~d}$. The level of uncertainty for the distribution of drawdown over a time period $>10 \mathrm{~d}$ was unreasonable.

Sensitivity runs were performed by varying horizontal hydraulic conductivity by an order of magnitude (plus/minus), changing the anisotropy ratio to 10 and 16 . The results of the sensitivity analysis are summarized in Table 4.2.

\subsection{CONCEPTUAL DESIGN}

The conceptual design for the pumping test is based on information available from previous aquifer tests (Geraghty \& Miller, Inc. 1986), on the conceptual model described in Chap. 3 , and on the capture zone modeling above.

The observation well network with the optimum locations relative to the extraction well for monitoring the anticipated drawdown in the aquifer should contain sufficient numbers of wells that satisfy the following location criteria:

- screened intervals at similar depths to the extraction well screen and along strike,

- screened intervals at various depths relative to the extraction well screen and down dip,

- screened intervals at various depths relative to the extraction well screen and up dip, and

- screened intervals at various depths relative to the extraction well screen and across strike.

Based on the site conceptual model and existing data from the previous pumping tests, the most extensive drawdown is anticipated along strike and down dip from the extraction well; therefore, the observation well network should prioritize wells along strike and down dip. A smaller number of observation well screens should be located across strike. An observation well network that satisfies all of the above criteria will allow definition of the drawdown response in three dimensions and will concentrate the observation points in the likely plane of maximum drawdown from the extraction well. In addition, background observation wells located outside the likely capture zone should be available for changes in barometric pressure and recharge events.

\subsubsection{Selection of Pumping and Observation Wells}

Figure 4.3 shows the distribution of screened intervals for wells located at the S-3 Site relative to their height in the stratigraphic column. This figure was used as a tool to determine which wells have screened intervals located at similar heights in the stratigraphic column. There appear to be three clusters of wells located in similar stratigraphic intervals. 
Table 4.2. Results of sensitivity analysis based on 30-d pumping at a constant rate of $1.5 \mathrm{gpm}$

\begin{tabular}{cllccc}
\hline $\begin{array}{c}\text { Sensitivity } \\
\text { run no. }\end{array}$ & \multicolumn{1}{c}{ Parameter } & Value used & $\begin{array}{c}\text { Sensitivity } \\
\text { run value }\end{array}$ & $\begin{array}{c}\text { Percent change in the } \\
\text { zone of influence } \\
\text { along strike }\end{array}$ & $\begin{array}{c}\text { Percent change in the } \\
\text { zone of influence } \\
\text { across strike }\end{array}$ \\
\hline 1 & $\begin{array}{l}\text { Hydraulic conductivity } \\
\text { (m/day) }\end{array}$ & 0.0275 & 0.275 & +57.3 & +57.9 \\
2 & $\begin{array}{l}\text { Hydraulic conductivity } \\
\text { (m/day) }\end{array}$ & 0.0275 & 0.00275 & $-55.8^{a}$ & $-55.9^{a}$ \\
3 & Horizontal anisotropy & 13 & 16 & +1.7 & -8.5 \\
4 & Horizontal anisotropy & 13 & 10 & -1.8 & +11.7 \\
5 & Storage coefficient & 0.0004 & 0.001 & -36.7 & -36.8 \\
6 & Storage coefficient & 0.0004 & 0.0001 & $+100.0^{a}$ & $+100.0^{a}$ \\
7 & Aquifer thickness (m) & 52.0 & 61.0 & +5.3 & +5.3 \\
8 & Aquifer thickness (m) & 52.0 & 45.7 & $-4.0^{a}$ & $-4.0^{a}$ \\
\hline
\end{tabular}

${ }^{a}$ The pumping well will become dry before the $30-\mathrm{d}$ pumping period if the discharge rate is maintained at $1.5 \mathrm{gpm}$. 


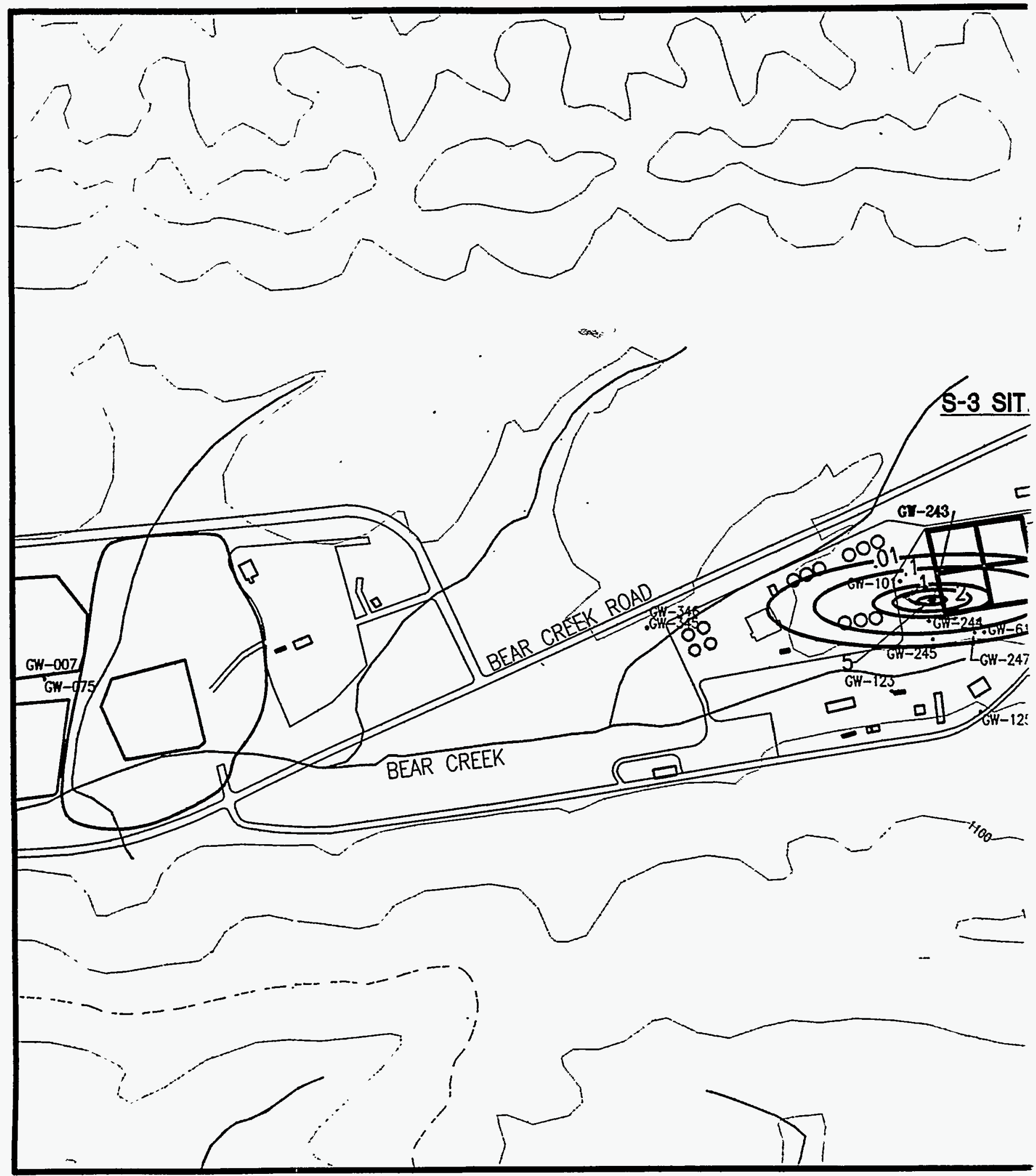

Fig. 4.1. Projected drawdown curves at 


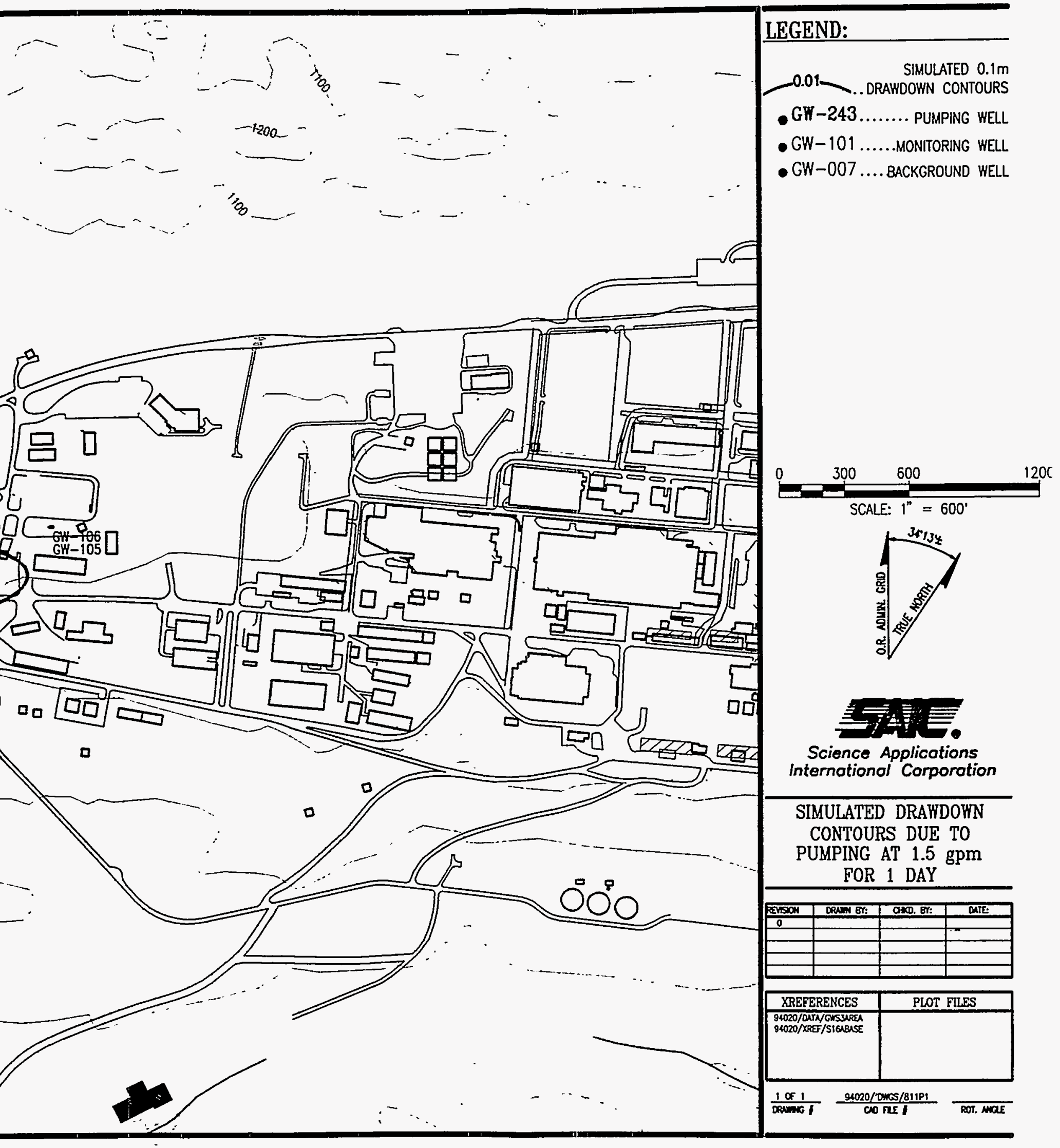

end of $1 \mathrm{~d}$ of pumping at the rate of $1.5 \mathrm{gpm}$. 


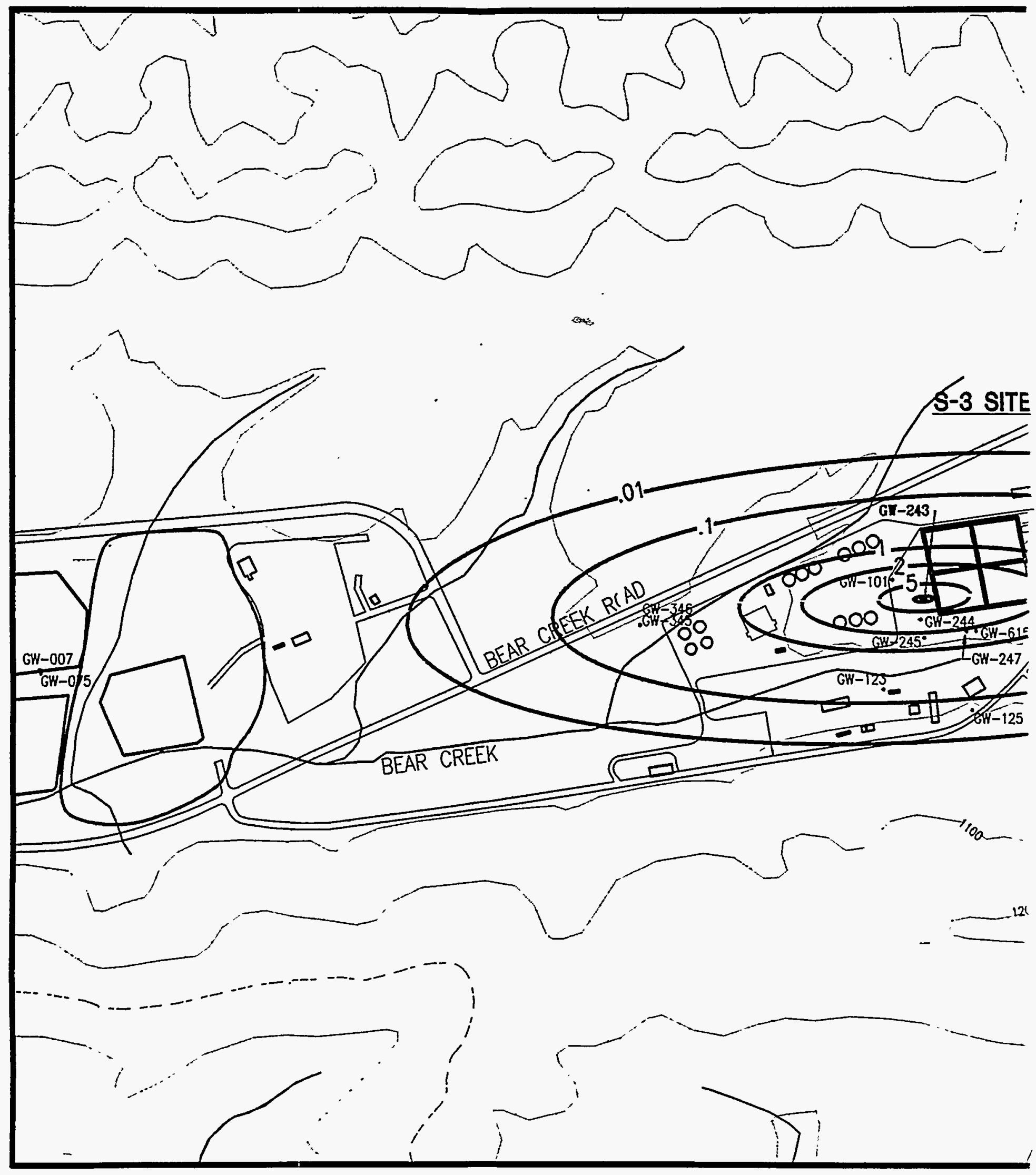

Fig. 4.2. Projected drawdown curves at the $\epsilon$ 


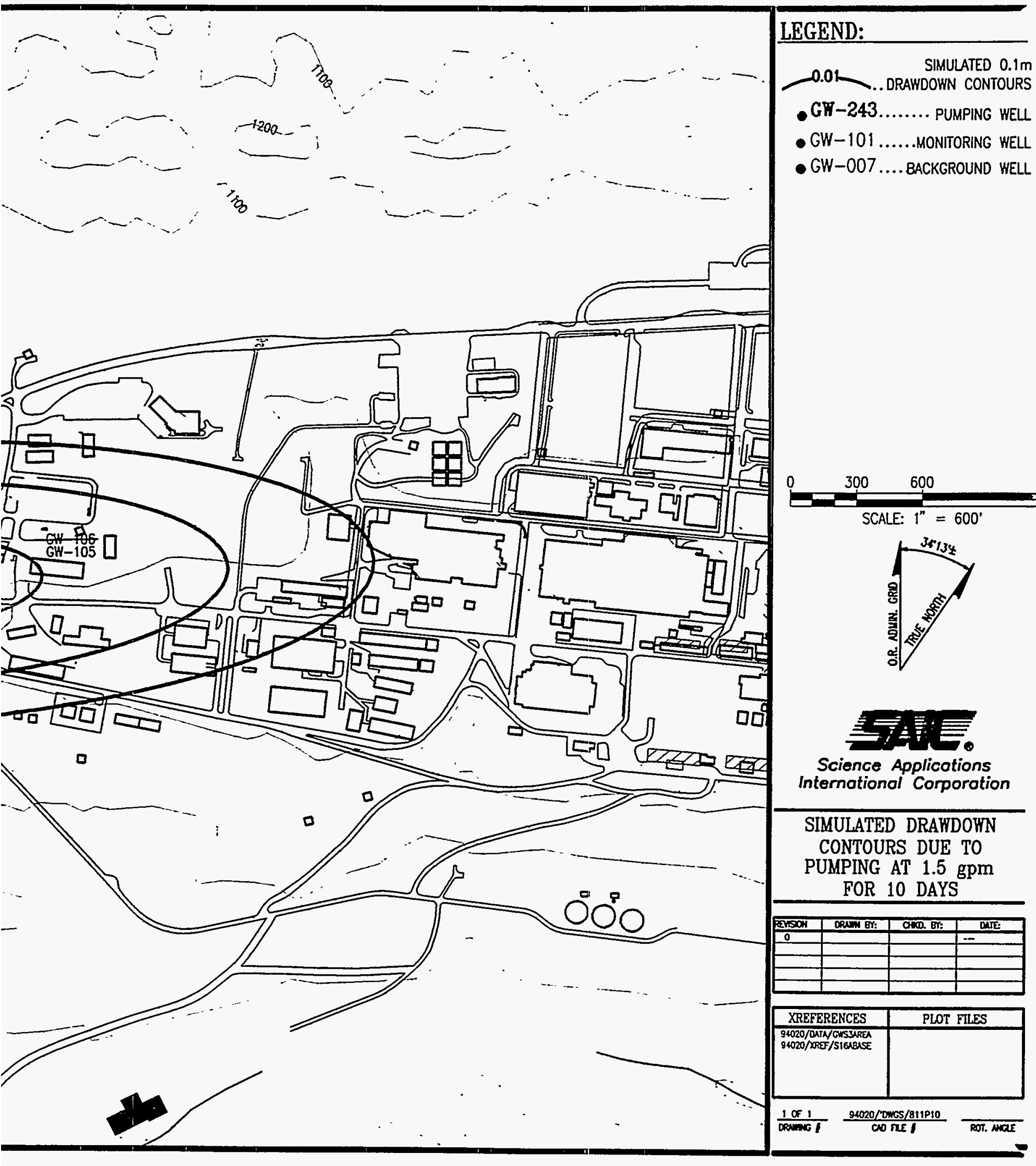

$10 \mathrm{~d}$ of pumping at the rate of $1.5 \mathrm{gpm}$. 


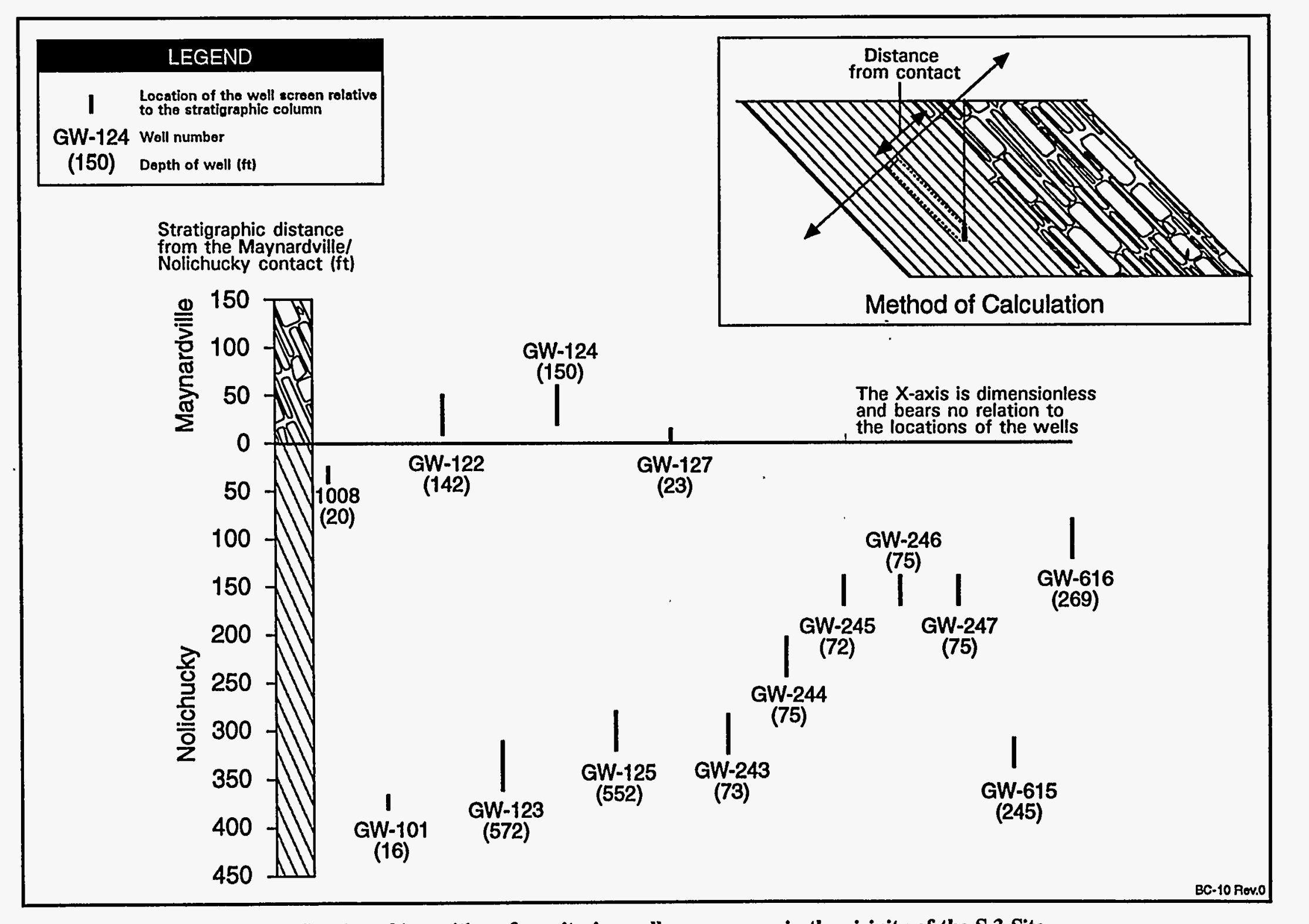


- Set 1. Screened close to the Nolichucky Shale-Maynardville Limestone boundary (1008, GW-122, GW-124, and GW-127).

- Set 2. Screened between -150 and 200 stratigraphic feet below the contact (GW-245, GW-246, and GW-247).

- Set 3. Screened between $\sim 300$ and 400 stratigraphic feet below the contact (GW-101, GW-123, GW-125, GW-243, and GW-615).

For a set of observation wells to satisfy the optimum criteria discussed above, the wells screened along strike, up dip, or down dip from the extraction well will be derived from the same set as the extraction well. This was observed during the Geraghty \& Miller, Inc. (1986), pumping test at the S-3 Ponds: well GW-245 was the extraction well, and the only wells that showed measurable response to pumping were GW-246 and GW-247. These three wells (GW-245, GW-246, and GW-247) constitute Set 2 above. Wells from Sets 1 or 3 that were monitored did not respond to pumping.

Wells from Set 1 are screened either in the Maynardville Limestone or in the Nolichucky Shale close to the contact and are not representative of the Nolichucky Shale at the S-3 Site.

Wells from Set 2 are all located at the same depth interval and along strike. These wells showed good response to pumping when one of the set was pumped (Geraghty \& Miller, Inc. 1986). Although along-strike drawdown is likely to be recorded using this set, no data would be available for the extent of the drawdown down dip or up dip from the extraction well.

Wells from Set 3 are located at a variety of depth intervals and are screened at the same stratigraphic interval. Pumping from one well in this set may allow definition of the up/down dip extent of drawdown created by pumping. From this set, well GW-243 is probably the best suited for an extraction well because it is a bedrock well in the intermediate interval. Well GW-101 is screened in the residuum, and GW-123, GW-125, and GW-615 are screened in the intermediate-to-deep aquifer. However, Set 3 does not satisfy the criteria of having wells along strike and at the same depth as the extraction well.

From this analysis of the available wells at the S-3 Site, it is apparent that there is no single extraction/observation well network that will satisfy the optimum criteria listed above. The two most likely sets of wells only partially satisfy these criteria. For the purpose of this decision document, GW-243 was chosen as the extraction well and wells from Set 3 and selected across strike and background wells were chosen for observation wells. Based on the drawdown distributions generated by analytical modeling of pumping well GW-243, some additional along-strike wells that are located farther from the S-3 Site have been included as monitoring wells. The complete list of observation wells is contained in Table 4.3.

\subsubsection{Water Level Measurements}

Water levels will be monitored using electronic pressure transducers connected to the data logger in the pumping well, the observation wells, and the background wells throughout the duration of the pumping and the 30-d recovery period. In the pumping well, water level, flow rate, $\mathrm{pH}$, conductivity, and temperature will be logged every $10 \mathrm{~s}$ for the first $2 \mathrm{~min}$ of pumping, every $30 \mathrm{~s}$ from 2 to $5 \mathrm{~min}$ from the start of pumping, every $1 \mathrm{~min}$ for 5 to $15 \mathrm{~min}$ of pumping, every $5 \mathrm{~min}$ from 15 to $60 \mathrm{~min}$ of pumping, every $10 \mathrm{~min}$ from 1 to $6 \mathrm{~h}$ of pumping, every $15 \mathrm{~min}$ from 6 to 48 hours of pumping, and every $30 \mathrm{~min}$ for the remainder 
Table 4.3. Existing wells selected as monitoring wells for the pumping test

\begin{tabular}{|c|c|c|c|c|c|}
\hline \multirow[b]{2}{*}{ Well no. } & \multirow[b]{2}{*}{$\begin{array}{l}\text { Surface } \\
\text { elevation }\end{array}$} & \multirow[b]{2}{*}{$\begin{array}{l}\text { Bottom } \\
\text { elevation }\end{array}$} & \multicolumn{2}{|c|}{ Monitor interval } & \multirow[b]{2}{*}{$\begin{array}{c}\text { Interval } \\
\text { type }\end{array}$} \\
\hline & & & $\begin{array}{c}\text { Top } \\
\text { elevation }\end{array}$ & $\begin{array}{l}\text { Bottom } \\
\text { elevation }\end{array}$ & \\
\hline GW-101 & 1006.0 & 988.5 & 993.7 & 989.7 & Screened \\
\hline GW-105 & 1014.1 & 997.1 & 1002.0 & 998.0 & Screened \\
\hline GW-106 & 1014.3 & 939.3 & 952.4 & 943.4 & Screened \\
\hline GW-123 & 1004.4 & 432.4 & 482.4 & 432.4 & Open \\
\hline GW-125 & 1004.0 & 452.0 & 502.0 & 452.0 & Open \\
\hline GW-243 & 1008.6 & 931.6 & 963.6 & 935.7 & Screened \\
\hline GW-244 & 1006.9 & 929.9 & 955.6 & 931.5 & Screened \\
\hline GW-245 & 1006.1 & 930.1 & 959.6 & 931.5 & Screened \\
\hline GW-246 & 1006.1 & 930.1 & 959.6 & 931.5 & Screened \\
\hline GW-345 & 994.9 & 968.6 & 978.9 & 968.9 & Screened \\
\hline GW-346 & 995.1 & 929.8 & 940.5 & 930.5 & Screened \\
\hline$G W-007^{b}$ & 962.5 & 946.0 & 950.2 & 948.2 & Screened \\
\hline GW-075 & 962.1 & 762.1 & 782.5 & 762.5 & Screened \\
\hline GW-615 & 1016.8 & 769.2 & 791.7 & 769.2 & Open \\
\hline
\end{tabular}

aPumped well.

background well.

of the pumping test. Table 4.4 presents a range of intervals for data logging of water level in the monitoring wells and the background well. Daily rainfall data will also be collected at the site. During the recovery period, data logging of water level in the pumping well will follow the same intervals immediately after cessation of pumping as those to be logged from the start of the pumping. Data logging of water level in the monitoring wells and the background well after pumping ceases will follow the intervals presented in Table 4.4. Water levels in all of the wells, including the pumping well, will also be logged for $7 \mathrm{~d}$ before the test begins to identify the pretest water level trends.

\subsubsection{Chemical Analysis}

Samples will be collected at regular intervals from the pumping well during the pumping and recovery period. The samples will be sent to the Y-12 Plant laboratory for nitrate, cadmium, and ${ }^{90} \mathrm{Sr}$ analysis. The sampling and analysis plan will provide the details of the analytical requirements as well as prepumping and postpumping sampling plans. Nitrate will be monitored as representative of chemically conservative chemicals, cadmium as representative of metals that are highly susceptible to sorption reactions, and ${ }^{90} \mathrm{Sr}$ as representative of metals and radionuclides that tend to sorb but are not as particle reactive as cadmium. All chemicals are considered to be affected by matrix diffusion. In addition, groundwater samples 
Table 4.4. Range of intervals between the water level measurements

\begin{tabular}{ll}
\hline \multicolumn{1}{c}{$\begin{array}{c}\text { Time since } \\
\text { start of pumping }\end{array}$} & \multicolumn{1}{c}{$\begin{array}{c}\text { Time } \\
\text { intervals }\end{array}$} \\
\hline 0 to $2 \mathrm{~min}$ & $10 \mathrm{~s}$ \\
2 to $5 \mathrm{~min}$ & $30 \mathrm{~s}$ \\
5 to $15 \mathrm{~min}$ & $1 \mathrm{~min}$ \\
15 to $60 \mathrm{~min}$ & $5 \mathrm{~min}$ \\
1 to $6 \mathrm{~h}$ & $10 \mathrm{~min}$ \\
6 to $48 \mathrm{~h}$ & $15 \mathrm{~min}$ \\
$2 \mathrm{~d}$ to remainder of pump & $30 \mathrm{~min}$ \\
test or recovery period & \\
\hline
\end{tabular}

will be collected from six wells prior to the test, weekly during the test, and once after the test. These samples will be analyzed for VOCs, semi-VOCs, radionuclides, nitrate/nitrite, and major ions.

\subsubsection{Interpretation of the Data}

The drawdown behavior will be compared with existing theoretical models (especially for fractured anisotropic aquifer), and the model that most closely compares with the real system will be selected for the calculation of the hydraulic characteristics. Mathematical models will be developed for the LTPT scenario to simulate the changes in nitrate, cadmium, and ${ }^{90} \mathrm{Sr}$ concentrations during the pumping period as well as during the recovery period until chemical equilibrium is reestablished. The calibrated model, based on the LTPT results, will be applied to other sites in the Nolichucky Shale to evaluate the pump-and-treat cleanup alternatives. 


\section{WASTE MANAGEMENT ISSUES}

\subsection{GROUNDWATER CONTAMINANTS}

Groundwater contaminants identified in groundwater monitoring well GW-243 at the S-3 Ponds include radionuclides, metals, VOCs, and ions. This well was sampled on a regular basis between 1987 and 1992. Well GW-243 was also sampled in 1994; however, analytical results are not yet available. Notable for treatment purposes is a $\mathrm{pH}$ of $\sim 3.5$ measured in the field. The following is a list of the main contaminants in Well GW-243:

- Radionuclides detected in the groundwater at elevated concentrations include ${ }^{231} \mathrm{Th}$, ${ }^{234} \mathrm{Th},{ }^{3} \mathrm{H},{ }^{90} \mathrm{Sr}$, and ${ }^{99} \mathrm{Tc}$.

- Dissolved metal contamination includes aluminum, barium, beryllium, boron, cadmium, cobalt, copper, iron, lead, mercury, nickel, silicon, silver, and zinc.

- Detectable VOC contamination includes acetone, chloroform, tetrachloroethene, trichloroethene, trichloroethane, toluene, methylene chloride, and dichloroethene.

- . Of the major cations and anions detected, nitrate occurs in elevated concentrations.

Further discussion of the groundwater contaminants related to the S-3 Ponds, and their solubility and interaction, can be found in Sect. 2.4.2.

\subsection{TREATMENT TRAIN}

Water pumped from the LTPT will require treatment and/or storage before it is released to the surface water of the Y-12 Plant. The primary link in the treatment train is the West End Treatment Facility (WETF); however, additional steps in the treatment process will most likely be needed. Figure 5.1 is a flow chart outlining the treatment train process.

\subsubsection{Pretreatment}

Pretreatment may be required for S-3 Site groundwater. Potential pretreatment concerns are suspended solids, ${ }^{99} \mathrm{Tc}$ and other soluble radionuclides, and calcium. This pretreatment step could be performed before the water is pumped into the truck for transport or at the WETF before treatment. Environmental Restoration (ER) requires that the water be filtered before it is pumped into the tanker truck; therefore, this filtration step must be performed at the site. This requirement limits the amount of sludge that accumulates in the tanker truck. The remainder of the pretreatment involves removing calcium and dissolved radionuclides, including ${ }^{99} \mathrm{Tc}$. This can be achieved by $\mathrm{pH}$ adjustment followed by zeolite filtration or ionexchange resins. Another technique that may be applicable involves precipitation of these dissolved contaminants using iron filings. This technique is currently being implemented at the Paducah Gaseous Diffusion Plant in Paducah, Kentucky. Further information concerning pretreatment can be obtained by jar testing from GW-243 at WETF. WETF will need to perform jar testing to determine exactly what kind of pretreatment will be required. 


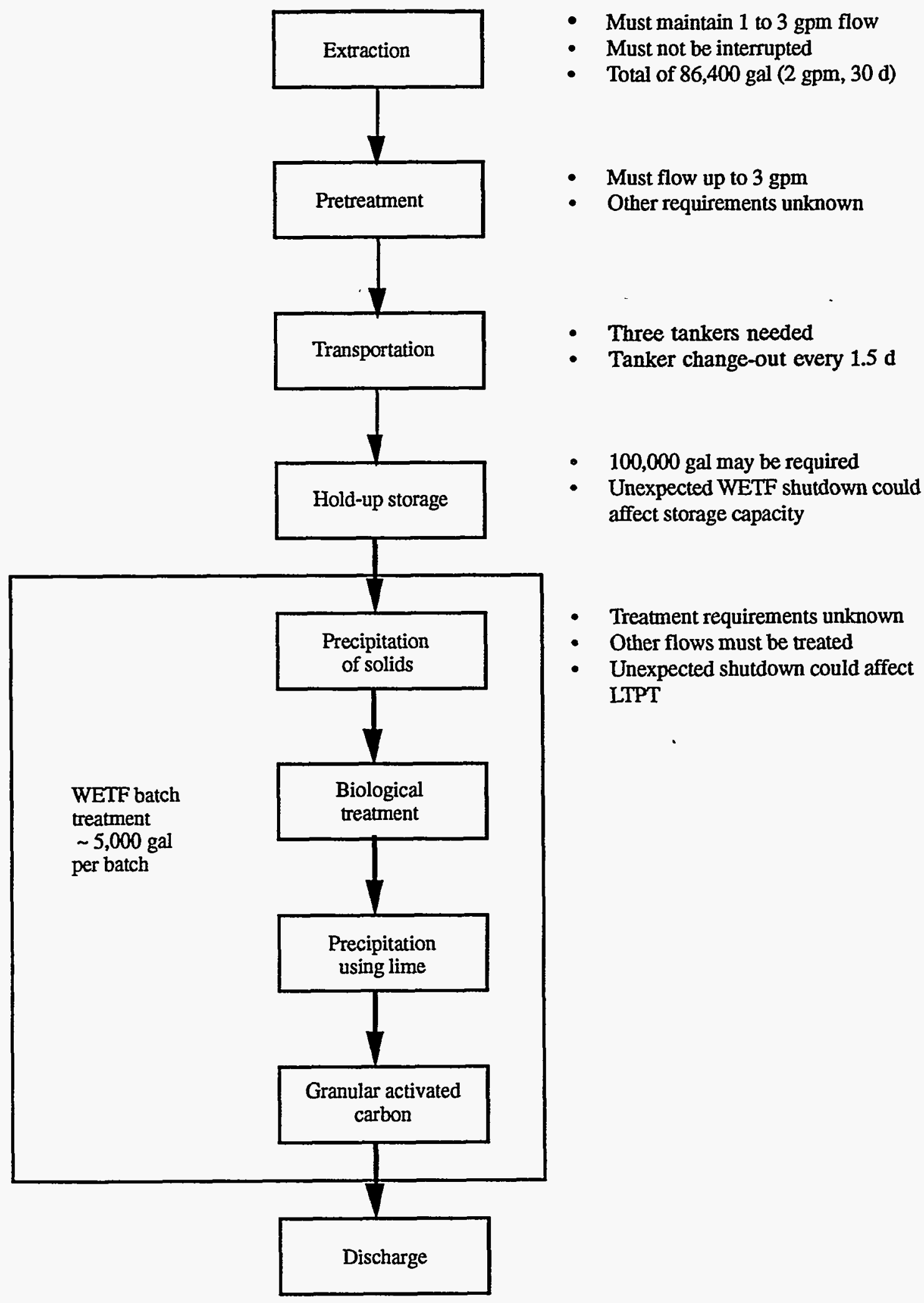

Fig. 5.1. LTPT treatment flow chart. 


\subsubsection{Transportation}

After filtration, and possibly pretreatment, groundwater will be transported by 10,000 -gal tanker trucks. Three tankers are preferred for this pump-and-treat test. No fewer than two tankers would be acceptable because a second tanker must be available to replace the first when it is full. Three tanker trucks would allow a maximum pump rate of 6 gpm (well in excess of the proposed 1.5-gpm flow rate), resulting in a buffer of 1000 gal and tanker exchange within $24 \mathrm{~h}$. Provisions must be made for weekend exchange of tankers.

\subsubsection{Hold-Up Storage}

The storage capacity will be provided in a single tank located within the WETF tank farm, which contains 12 tanks and has a total capacity of $\sim 6$ million gal. This volume is used for backlogged water requiring treatment. Currently, most of this capacity is filled. The projected storage capacity would become available in June 1995 when WETF operations eliminate this quantity of the current backlog. If an operational shutdown or slowdown occurs at WETF, this provision for the S-3 Site pumping test could be lost. Section 5.5.2 presents options if this occurs.

\subsubsection{Treatment}

Groundwater will be treated at WETF. The treatment train used by WETF is as follows:

- precipitation of solids,

- biological treatment of nitrates using acetic acid,

- precipitation of soluble contaminants using lime,

- final filtration of organics and metals using granular activated carbon, and

- discharge through a permitted National Pollutant Discharge Elimination System (NPDES) outfall.

\subsection{REGULATORY ISSUES}

Nearly all of the regulatory issues related to the LTPT are handled by WETF standard operating procedures. Regulations affecting the LTPT include the National Environmental Policy Act (NEPA); Clean Water Act; RCRA; and, for radioactive waste, the Atomic Energy Act of 1954, as amended.

\subsubsection{NEPA}

Any project constituting a major federal action must be reviewed in accordance with NEPA to determine the impact of the project on the environment. The NEPA Compliance Organization will be contacted to determine whether a NEPA review is necessary. If a NEPA review is required, the most likely documentation will be a categorical exclusion (CX). The NEPA Compliance Organization has a number of preapproved CXs, agreed to by DOE, based on general project types. 


\subsubsection{Clean Water Act}

The Clean Water Act requires facilities that discharge pollutants into the waters of the United States to have an NPDES permit. The Y-12 Plant is currently operating under an extension to its NPDES permit (No. TN0002968), which expired in 1990. It is expected that by the time the LTPT is implemented (June 1995) the new NPDES permit will have been negotiated and issued. All water discharged by this project will be managed through WETF. WETF is a permitted treatment facility and is in compliance with state and federal regulations regarding air and water. WETF releases treated water to UEFPC through an NPDESpermitted outfall (NPDES No. 502). Proper overall management of the WETF, including LTPT groundwater, will continue compliant discharge through WETF.

\subsubsection{RCRA}

Solid and hazardous waste generated during project activities and considered RCRA hazardous will be managed in accordance with RCRA and implementing regulations 40 CFR Parts 258 and 261 through 270 . Waste management can be implemented by involving the Waste Management Organization and preparing a waste management plan. Sludges and other waste generated by the WETF treatment process vill be handled according to WETF standard operating procedures.

\subsubsection{Atomic Energy Act of 1954, as Amended}

Should project activities result in the generation of radioactive waste, the waste will be managed in accordance with the Atomic Energy Act of 1954, as amended. Again, these wastes can best be managed by involving the Waste Management Organization and preparing a waste management plan. Sludges and other waste generated by the WETF treatment process will be handled according to WETF standard operating procedures.

\subsection{WASTE STREAMS}

Potential waste streams generated by pretreatment and WETF treatment of the LTPT groundwater might include any of the following: filter media, precipitated sludges, contaminated iron filings, resin, zeolite filters, and/or granular activated carbon. Generally, these waste streams will be dewatered, packaged, and disposed of. Filter media will be cloth or synthetic filter material and could be contaminated with radionuclides, sulfates, and organics. Precipitated sludges will most likely be primarily calcium and radionuclides. Iron filings, resin, or zeolite filters will be contaminated with radionuclides and other heavy metals. Granular activated carbon will be contaminated with organics and some metals.

Dewatering for the limited volumes of waste expected to be generated by this pump-andtreat test could be accomplished by air drying with appropriate containment of the media.

If these waste streams are not radioactively contaminated and pass toxicity characteristic leaching procedure (TCLP) tests, they could potentially be disposed of in the Y-12 Plant landfill. The waste streams would be analyzed and compared to the waste acceptance criteria for the landfill. If the waste streams showed radioactive contamination, they would be drummed and stored (most likely at the Oak Ridge K-25 Site). 
When more information about the well to be used for the pumping test is known, the volume of waste to be generated will be estimated and a waste management plan will be completed in accordance with ER procedure ER/C-P2101, "Preparation of Environmental Restoration Task/Project-Specific Waste Management Plans.” One waste management plan can be completed for all of the waste streams to be generated by the project.

\subsection{TRANSPORTATION, STORAGE, AND TREATMENT CAPACITY}

Capacities of transportation, storage, and treatment facilities related to the LTPT are critical to the success of the LTPT. All capacities must be verified and coordinated through open communication until implementation of the LTPT. Additionally, contingency plans should be prepared for the event that any of these capacities are diminished either before or during the implementation of the LTPT.

\subsubsection{Transportation Capacity}

The LTPT expects to maintain a flow rate of $6 \mathrm{gpm}$ or less and operate using three tankers with a total hold-up capacity of 18,000 gal (using $90 \%$ total capacity). At a flow rate of $6 \mathrm{gpm}$, the tankers would be changed out daily. At the proposed flow rate of $1.5 \mathrm{gpm}$, the tankers would be changed out every $3 \mathrm{~d}$. The procedure will attempt to limit the amount of time the test will be restricted to one tanker. Availability of three tankers will ensure continued operation of the LTPT.

\subsubsection{Storage Capacity}

ER has provided a storage capacity of 500,000 gal for use by the LTPT; this storage capacity will become available in June 1995. If a system shutdown or decreased treatment rate occurs at the WETF, the potential exists for this storage capacity to be reallocated to other groundwater waste streams. In the event of this occurrence, ER has the options of (1) making provisions to store $\sim 100,000 \mathrm{gal}$ of contaminated groundwater ( 1 month at $1.5 \mathrm{gpm}$ ), (2) requesting priority over other groundwater sources for storage and/or treatment, or (3) postponing the test until storage capacity is available.

\subsubsection{Treatment Capacity}

WETF projects a treatment capacity of $80,000 \mathrm{gal} /$ week for LTPT groundwater through batch processing operations as of June 1995. System shutdowns or unexpected operations limits could change this treatment capacity; these conditions will be monitored during the development of this test. A change in this capacity will not affect the performance of the LTPT unless it also affects the storage capacity to be made available for LTPT.

\subsection{WASTE MANAGEMENT}

Management of wastes generated by the LTPT will be the overall responsibility of ER, although some wastes will be managed by WETF standard operating procedures. Wastes specifically under the responsibility of ER include filter medium, pretreatment wastes, personal protective equipment (PPE), and other equipment. Sludges and granular activated carbon will be managed by WETF. 


\subsubsection{Filter Medium}

The filter medium most likely will be a vendor-supplied cloth, paper, or synthetic material. The primary function of this filter is to prevent suspended solids (primarily silt) from accumulating in the tanker. The filter will likely become contaminated with other suspended or nonsoluble contaminants from the groundwater, possibly including some radioactive contamination and metals. The filters will then be dewatered and analyzed for radiological contamination and TCLP contaminants. The filters could then be treated as sanitary, radioactive, or mixed waste. If classified as sanitary waste, the filters could be disposed of in the Y-12 Plant sanitary landfill. If classified as radioactive or mixed waste, the filters will be placed in $17 \mathrm{C}$ drums and stored for permanent disposal (most likely at the K-25 Site).

\subsubsection{Sludge}

Sludge/precipitate may be generated by pretreatment and by the precipitation steps in the WETF processes. This sludge must be dewatered and characterized prior to disposal. For the limited amount of sludge/precipitate likely to be generated by the LTPT, a drying bed designed to capture all runoff for treatment could be constructed. All of the sludge/precipitate is expected to be radioactively contaminated. After dewatering, the sludge will be packaged in $17 \mathrm{C}$ drums for storage, pending determination of suitable disposal.

\subsubsection{Iron Filings}

If iron filing treatment technology is implemented as a pretreatment activity, the contaminated iron filings will be managed as a waste stream. These filings are expected to be radioactively contaminated. Dewatering of the filings should be relatively easy and can be accomplished as described in Sect. 5.6.2. The filings also will be packaged in $17 \mathrm{C}$ drums for storage, pending determination of suitable disposal. The filings could have sufficiently low radioactive contamination to pass RCRA TCLP testing. If these conditions are met, the filings may be suitable for noncontainerized landfill disposal. This determination could be made by field sampling of filings.

\subsubsection{PPE and Other Equipment}

Most environmental field activities generate contaminated PPE. PPE for the LTPT will be limited to gloves and Tyvek" suits with very low levels of contamination. After it has been screened for radioactive contamination, this material can be bagged and disposed of in the Y-12 Plant sanitary landfill. Equipment may include tubing, paper towels, and plastic sheeting and will also be disposed of at the Y-12 Plant sanitary landfill if chemical and radiological levels are within acceptable limits.

\subsubsection{Granular Activated Carbon}

Granular activated carbon used for final filtration of LTPT groundwater will most likely not be radioactively contaminated. The carbon will have organic contamination and some metals. If this waste stream passes TCLP, it can be disposed of at the Y-12 Plant sanitary landfill. If it is considered RCRA waste, it will be placed in 17C drums and stored for permanent disposal (most likely at the K-25 Site). 


\subsection{COST ISSUES}

Although treatment at WETF is budgeted separately from ER activities and will not represent any direct cost to ER, other activities related to the treatment and waste management of the LTPT will have associated cost issues.

\subsubsection{Pretreatment}

ER will be responsible for pretreatment costs. Contaminated water will have to be filtered before it can be pumped into the tanker trucks for transport. This can be accomplished using a commercially available mobile filtration unit with filters sized according to the expected particle size and fine-tuned during operation to achieve maximum flow while providing maximum filtration benefit. Additional pretreatment for calcium, ${ }^{99} \mathrm{Tc}$ and other dissolved radionuclides, and other dissolved solids may be necessary based on the requirements of WETF. This pretreatment step could also be performed by a commercially available mobile treatment unit or at WETF using existing equipment.

\subsubsection{Transport}

The tankers that will be used to transport the contaminated water are owned by ER and will have no associated cost. However, a driver will be required to drive a full tanker from the well to WETF and, after the tanker has been emptied, from WETF to the well. It is assumed that this driver could be obtained for a limited amount of time daily and would be available for weekend work to accommodate 24-h operation of the LTPT.

\subsubsection{Chemical Operators}

ER will provide system operators to monitor and operate the pumping system for 24-h operation. Daily requirements will be monitoring and documenting the amount of water pumped, flow rate, well drawdown, and general system operation. These individuals will also manually switch over the tankers and connect or disconnect the piping for transport to WETF. At least one system operator will be on duty at all times, $24 \mathrm{~h} / \mathrm{d}$, including all weekends, to maintain continuous operation of the LTPT for its projected 1-month operation.

\subsubsection{Sampling}

Sampling for WETF, other than characterization sampling, performed before or during the LTPT will be coordinated by ER, and sample analysis will be funded by ER. The number and frequency of sampling and the laboratory analysis to be performed will be defined prior to initiation of the test.

\subsubsection{Treatment}

There will be no cost to ER associated with the storage or treatment of contaminated groundwater from the LTPT. Money for operation of WETF is allocated under a separate budget and will not require reimbursement from ER. 


\section{HEALTH AND SAFETY CONCERNS AND QUALITY ASSURANCE/QUALITY CONTROL ISSUES}

This portion of the Phase I effort identifies substantive issues pertaining to the development of a project health and safety plan and a quality assurance project plan for the LTPT. The scope of activities and a framework for preparing these plans to assist in evaluating the technical feasibility and costs associated with subsequent phases of the LTPT are defined in this chapter.

\subsection{HEALTH AND SAFETY CONCERNS}

This section is a short overview of the hazards and probable hazard control measures associated with conducting a pump-and-treat test near the S-3 Ponds. A detailed health and safety plan containing hazards analyses and specific controls will be prepared and approved by Y-12 Plant management before the pump-and-treat test is conducted. The health and safety plan will include a description of the site (emphasizing site hazards), the project organization, the tasks to be performed, the hazards associated with each task, hazard controls for each task, required PPE, monitoring requirements, and emergency procedures and contacts.

Prior analyses of groundwater near the ponds indicate contamination with a variety of materials, including metals, VOCs, and radioisotopes. The greatest reported concentration of any metal was $140 \mathrm{mg} / \mathrm{L}$ of barium. The greatest reported concentration of VOCs was $2200 \mu \mathrm{g} / \mathrm{L}$ of tetrachloroethene. The greatest reported concentration of any radioisotope was $62,932 \mathrm{pCi} / \mathrm{L}$ of ${ }^{99} \mathrm{Tc}$. The concentrations of metals and VOCs do not appear to present any potential for overexposure during the planned tasks. The concentrations of radioisotopes do present some potential for overexposure.

The specific tasks involved in the project are installation of the pump-and-treat system, operation of the on-site treatment system for a specified period of time, and transportation of pretreated water to WETF.

The primary hazards include temperature extremes, potential accidents involving equipment operation, radioisotope (contamination) exposure, and exposure from chemicals brought on site in the course of the work.

These hazards will be controlled by applying general and specific hazard controls. Many of these controls are contained in existing Y-12 Plant procedures. Others will be developed specifically for this project. Examples of these controls are work/rest regimens and appropriate clothing to control temperature stress; staying clear of moving or rotating equipment; wearing work gloves for tasks that pose abrasive or cutting hazards; wearing anti-C clothing as appropriate; and using standard practices such as hazardous waste safety training, site-specific safety training, medical surveillance of employees, and labeling of hazardous materials containers. 
The project field operations manager and the health and safety officer will routinely observe the work place and work practices to verify effective and sufficient hazard control. Monitoring for hazardous exposures and contamination will be conducted with radiation detection devices. This monitoring will include whole-body dosimetry and real time alpha and beta/gamma measurements. Organic vapor monitoring may also be conducted. Project personnel and Y-12 Plant oversight personnel have the authority and responsibility to stop any part of the project if it appears to be unsafe.

\subsection{QUALITY ASSURANCE/QUALTTY CONTROL ISSUES}

Quality assurance/quality control measures for the LTPT will be developed in accordance with the requirements of EPA (QAMS-005/80, Interim Guidelines and Specifications for Preparing Quality Assurance Project Plans), DOE (5700.6C, "Quality Assurance"), and Energy Systems (ES/ER/TM-4/R4, Environmental Restoration Quality Program Plan). Quality-related activities planned for the LTPT include groundwater sampling and analysis, measurement of hydrologic parameters, documentation of LTPT activities, data management, data analysis, and reporting. The required levels of quality assurance/quality control will be determined by the relative sensitivity of LTPT objectives to each activity and to the data derived from the activity. Because the objective of the LTPT is to determine the feasibility of a potential remedial technology-and not to characterize the nature or risk of groundwater contamination-the level of quality assurance/quality control will be defined to meet this objective.

A brief discussion of the elements of the LTPT quality assurance project plan, focused on defining the scope and framework of the plan, is presented below. Table 6.1 crossreferences the required elements of quality assurance project plans specified by EPA and Energy Systems as they will be presented in the LTPT work plan.

\subsubsection{Quality Assurance Objectives}

The objective of the quality assurance project plan will be to establish procedures and requirements to ensure that work performed and data collected during the LTPT are sufficient and reliable indicators of the practicability and effectiveness of pump-and-treat technology as a groundwater cleanup alternative. To achieve this objective, parameters must be developed that describe the sensitivity of the data collected to error. These parameters are precision, accuracy, representativeness, completeness, and comparability (PARCC).

A relatively high level of precision will be required for several sensitive measurement activities (e.g., hydrologic and analytical data), and standard levels of precision will be required for other quality-related activities. Because risk-based decisions will not be made on the basis of these data, there is no elevated sensitivity to data accuracy for the LTPT. A principal objective of the LTPT is to provide hydrologic and chernical data representative of the upper Bear Creek Nolichucky Shale. The greatest uncertainty in data representativeness is the inherent variability of the hydrologic and contaminant release/transport system being tested, which will be a principal factor in designing the LTPT. Data completeness goals will be developed based on the sensitivity of the LTPT DQOs to each data collection activity. Comparability will be established by implementing well-defined sampling and analytical methodologies and quality assurance measures. The greatest uncertainty for data PARCC is 
Table 6.1. Modular profile and cross-reference of EPA QAMS-005/80 and ES/ER/TM-4/R4 elements

EPA QAMS-005/80 element

1. Title page

2. Table of contents

3. Project description

4. Project organization and responsibility

5. Quality assurance objectives

6. Sampling procedures

7. Sample custody

8. Calibration procedures and frequency

9. Analytical procedures

10. Data reduction, validation, and reporting

11. Internal quality control checks

12. Performance and system audits

13. Preventive maintenance

14. Specific routine procedures used to assess data PARCC
Location in LTPT work plan

p. $\mathbf{i}$

6. Document control

6. Document control

pp. iii-viii

2. Quality assurance program

6. Document control

Sect. 1.1

Sect. 1.1

1. Organization

Chap. 7

3. Design control

Sect. 6.2.1

3. Design control

Sect. 6.2 .2

6. Document control

9. Control of processes

Sect. 6.2 .2

Sect. 6.2 .2

13. Handling, storage, and shipping

6. Document control

8. Identification and control of items

Sect. 6.2 .2

Sect. 6.2 .2

Sect. 6.2.2

Sect. 6.2 .5

12. Control of measuring and test equipment

9. Control of processes

Sect. 6.2.3

3. Design control

Sect. 6.2 .6

3. Design control

Sect. 6.2.4

18. Audits and surveillances

Sect. 6.2 .7

12. Control of measuring and test equipment

Sect. 6.2 .5

3. Design control

Sect. 6.2.7 
Table 6.1 (continued)

\begin{tabular}{|c|c|c|c|c|}
\hline \multicolumn{2}{|r|}{ EPA QAMS-005/80 element } & \multicolumn{2}{|r|}{ ES/ER/TM-4/R4 element } & \multirow{2}{*}{$\begin{array}{c}\begin{array}{c}\text { Location in LTPT } \\
\text { work plan }\end{array} \\
\text { Sect. } 6.2 .7 \\
\text { Sect. } 6.2 .7\end{array}$} \\
\hline 15. & Corrective actions & $\begin{array}{l}18 . \\
15 .\end{array}$ & $\begin{array}{l}\text { Audits and surveillances } \\
\text { Control of nonconforming items }\end{array}$ & \\
\hline 16. & $\begin{array}{l}\text { Quality assurance reports to } \\
\text { management }\end{array}$ & $\begin{array}{l}2 . \\
16 .\end{array}$ & $\begin{array}{l}\text { Quality assurance program } \\
\text { Corrective action }\end{array}$ & $\begin{array}{l}\text { Sect. } 6.2 .7 \\
\text { Sect. } 6.2 .7\end{array}$ \\
\hline 17. & $\begin{array}{l}\text { Other quality assurance/ } \\
\text { quality control measures to } \\
\text { meet ES/ER/TM-4/R4 } \\
\text { requirements }\end{array}$ & $\begin{array}{l}4 . \\
5 . \\
7 . \\
10 . \\
11 . \\
14 . \\
17 . \\
19 .\end{array}$ & $\begin{array}{l}\text { Procurement document control } \\
\text { Instructions, procedures, } \\
\text { and drawings } \\
\text { Control of purchased items and } \\
\text { services } \\
\text { Inspection } \\
\text { Test control } \\
\text { Inspection test and operating } \\
\text { status } \\
\text { Quality assurance records } \\
\text { Software quality assurance }\end{array}$ & $\begin{array}{l}\text { Sect. } 6.2 .7 \\
\text { Sect. } 6.2 .7 \\
\text { Sect. } 6.2 .7 \\
\text { Sect. } 6.2 .7 \\
\text { Sect. } 6.2 .7 \\
\text { Sect. } 6.2 .7 \\
\text { Sects. } 6.2 .6,6.2 .7 \\
\text { Sect. } 6.2 .6\end{array}$ \\
\hline
\end{tabular}


the variability inherent in the contaminant release/transport system being tested during the LTPT; this uncertainty will be addressed by the testing design.

\subsubsection{Sampling and Custody Procedures}

It is anticipated that Energy Systems Environmental Surveillance Procedures (ESPs) will govern sampling and custody activities during the LTPT. The ESPs are compatible with industry practices for these activities and have been approved by EPA for use during qualityrelated activities. In addition, the work practices and level of documentation provided by the ESPs meet the LTPT DQOs. It may be necessary to develop LTPT-specific procedures; if so, they will provide for a similar level of quality assurance.

\subsubsection{Analytical Procedures}

Analytical data produced during the LTPT will be used to assess the effectiveness of pump-and-treat technology in the removal of contaminants from groundwater and the aquifer matrix. Trends in the concentrations of discrete analytes will be a sensitive data input for the LTPT. For this reason, relatively precise analytical data (high-quality field laboratory or fixedbase analytical laboratory) will be necessary. However, high levels of laboratory documentation will not be necessary to fully assess and certify that the data achieve PARCC. Standard field and analytical quality control results, laboratory instrument calibrations, and laboratory audits will be adequate to provide measures of the confidence in the data.

\subsubsection{Quality Control Measures}

Standard elements of field and laboratory quality control will be implemented during the LTPT. Field and laboratory duplicates and matrix spike samples will be used to measure the precision of the analytical data. Due to the anticipated low concentrations of some of the analytes of interest, field blanks, trip blanks, and equipment rinsates will be taken at a percentage of the total number of samples to assess cross-contamination. Additional laboratory quality control may be required if the method or instrument uncertainty results in an analytical measure of PARCC that does not meet the LTPT DQOs.

\subsubsection{Equipment Calibration and Maintenance}

Measuring and test equipment used during the LTPT will be calibrated to factory specifications prior to use. Routine and ongoing calibration frequency will be determined based on the manufacturers' recommendations and the sensitivity of the activity/data being measured. Health and safety monitoring instruments will be calibrated as defined in the health and safety plan. Records of factory certification and routine calibration will be maintained to provide a measure of data comparability.

\subsubsection{Data Management}

Data collected during the LTPT will consist of field observations (written and electronic), quality assurance/quality control records (e.g., calibration certifications and audit reports), and laboratory analytical results. Primary and secondary data sources will be identified in the quality assurance project plan. Specific methods for identifying, collecting, and capturing primary data will be defined (e.g., using preprinted logbooks, maintaining backup copies of electronic data logger outputs, and laboratory data package specifications). It is anticipated 
that only a representative fraction of the LTPT primary data will require formal data validation. All primary data will be reduced and compiled to a relational data base that is compatible with the Oak Ridge Environmental Information System (OREIS) format. Records of all primary and secondary data will be maintained in a project file.

\subsubsection{Quality Assurance Measures}

Quality assurance measures implemented during the LTPT will include audits, surveillances, defined routine methods for assessing the data PARCC, control of nonconforming items and corrective actions, quality assurance reports to management, procurement and document control, test and inspection control, and records management. Because the general level of sensitivity for LTPT data is lower than many Energy Systems ER data collection activities (i.e., remedial investigation/feasibility study), Energy Systems ER programmatic standards for quality assurance measures are anticipated to meet the LTPT DQOs. Specific programmatic measures, performance criteria, and schedules for quality assurance measures will be defined in the quality assurance project plan. 


\section{COSTS}

This chapter is intended to identify major cost items associated with conducting an LTPT. The purpose of this exercise is not to present a detailed cost breakdown for an LTPT but to identify major cost items so that a general idea of the cost in "ball park" numbers can be obtained. These costs will be used, along with the technical information presented elsewhere in this document, to make an informed decision on whether to conduct an LTPT. The costs are based on the conceptual design presented in Chap. 4 and on waste management issues discussed in Chap. 5. Because the LTPT has not yet been fully designed, there is high uncertainty associated with major cost items such as pretreatment and waste management. Thus, it is not prudent to perform detailed analysis of the cost items that can be determined at this time such as pumps and sampling. These costs should not be used in any capacity other than the purpose stated above. Assumptions stated in this section are solely for the use of developing the estimate. These assumptions may change if a decision is made to conduct the pumping test and a system needs to be designed.

The cost estimate is presented in Table 7.1. Assumptions used to develop this estimate and a description of each cost element are presented below.

- Other than pretreatment, waste treatment costs are not included in this estimate.

- The actual test duration is $62 \mathrm{~d}$; this includes $2 \mathrm{~d}$ for monitoring ambient conditions, $30 \mathrm{~d}$ of pumping, and $30 \mathrm{~d}$ to monitor the recovery.

- Ten observation wells and two background wells will be monitored for the duration of the test.

- Only one well will be pumped; the rate of withdrawal will be $1.5 \mathrm{gpm}$ for a total of $\sim 65,000$ gal.

- Tanker trucks will be supplied at no cost to the project, and three tanker trucks will be available.

- One tanker will be transported to the WETF every $1.5 \mathrm{~d}$ for a total of 20 trips.

- A pretreatment system will be required to remove uranium and technetium.

- Sludge generated during the pretreatment test will be a mixed waste.

- The water pumped from the well will be classified as a RCRA hazardous waste.

- All labor is assumed to cost $\$ 80 / \mathrm{h}$.

- The pretreatment unit has a capacity of at least $2 \mathrm{gpm}$ and is capable of removing suspended solids and various metals and radionuclides.

- Pretesting by Waste Management is required prior to the test. 


\section{7-2}

Table 7.1. Major cost items for the LTPT

\begin{tabular}{|c|c|c|c|c|}
\hline Activity & $\begin{array}{c}\text { Labor } \\
\text { costs } \\
(\$) \\
\end{array}$ & $\begin{array}{l}\text { Other } \\
\text { direct } \\
\text { costs } \\
(\$)\end{array}$ & $\begin{array}{l}\text { Subcontractor } \\
\text { costs } \\
(\$)\end{array}$ & $\begin{array}{c}\text { Subtota } \\
(\$)\end{array}$ \\
\hline Prepare and approve plans & 10,000 & & & 10,000 \\
\hline \multicolumn{5}{|l|}{ Mobilization } \\
\hline $\begin{array}{l}\text { Install pump and pressure } \\
\text { transducers }\end{array}$ & 5,760 & 42,000 & & 47,760 \\
\hline Install electrical outlets & 59,000 & & & 59,000 \\
\hline Bring field office on site & 640 & 2,000 & & 2,640 \\
\hline Bring tankers on site & 640 & & & 640 \\
\hline Data management & 19,200 & & & 19,200 \\
\hline \multicolumn{5}{|l|}{ Implementation } \\
\hline Test equipment & 3,840 & & & 3,840 \\
\hline Pump well & 57,600 & & & 57,600 \\
\hline Sample discharge water & 46,800 & 5,000 & 27,950 & 79,750 \\
\hline Full suite sampling & 23,040 & 2,500 & 105,000 & 130,540 \\
\hline Monitor recovery & 19,200 & & & 19,200 \\
\hline \multicolumn{5}{|l|}{ Waste management } \\
\hline Waste Management pretesting & 19,200 & & 41,000 & 60,200 \\
\hline $\begin{array}{l}\text { Bring pretreatment unit on } \\
\text { site }\end{array}$ & 3,200 & 52,000 & & 55,200 \\
\hline $\begin{array}{l}\text { Purchase resin and pack } \\
\text { columns }\end{array}$ & 3,840 & 20,000 & & 23,840 \\
\hline Pretreatment & 19,200 & & & 19,200 \\
\hline $\begin{array}{l}\text { Performance design } \\
\text { specifications }\end{array}$ & 62,000 & & & 62,000 \\
\hline Mixed waste sludge disposal & 2,600 & 50,000 & & 52,600 \\
\hline Transportation to WETF & 640 & & & 640 \\
\hline \multicolumn{5}{|l|}{ Demobilization } \\
\hline Dismantle site & 5,760 & & & 5,760 \\
\hline Return tankers and field office & 1,280 & & & 1,280 \\
\hline \multicolumn{5}{|l|}{ Reporting } \\
\hline Evaluate data & 50,000 & & & 50,000 \\
\hline Produce report & 50,000 & & & 50,000 \\
\hline TOTAL & 463,440 & 173,500 & 173,950 & 810,890 \\
\hline
\end{tabular}

${ }^{a}$ Pretreatment criteria have been specified in general terms; thus, high uncertainty is associated with these costs. 
- Water samples needed to evaluate test results require a full suite ${ }^{*}$ of analysis before the start of the test from six wells and a full suite from five wells during each week of the test plus one after the test is completed. Thus, the total samples for which a full suite of analysis is required is 30 at a cost of $\$ 3.5 \mathrm{~K}$ each. In addition, water samples to be analyzed for nitrate, cadmium, and ${ }^{90} \mathrm{Sr}$ will be collected at the following intervals: one per hour for the first day of pumping, one every $5 \mathrm{~h}$ for the following 3 days, and one per day until pumping is terminated. One sample will also be taken $30 \mathrm{~d}$ after pumping. The total number of samples to be analyzed for this sampling is 65 at $\$ 430$ per sample.

The major cost items and associated activities are described as follows:

- Mobilization-This cost item includes actions necessary to implement the test. Major items include purchasing other direct costs and equipment; procuring subcontractors; installing the pump, pressure transducers, rigging, and electrical outlet; and locating the field office and tanker on site.

- Implementation-This cost item includes testing equipment, conducting the test, sampling discharge water, and monitoring recovery.

- Waste Management-This cost item includes pretreatment, disposal of pretreatment sludge, and transportation to the WETF. $x$.

- Demobilization-This cost element includes labor time to pack up equipment and return the test area to normal conditions.

A full suite of analysis includes VOCs, semi-VOCs, metals, radionuclides, nitrate/nitrite, and major ions. 


\section{REFERENCES}

DOE (U.S. Department of Energy). 1991. Order 5700.6C, “Quality Assurance.”

Domenico, P. A. and F. W. Schwartz. 1990. Physical and Chemical Hydrogeology, John Wiley and Sons, New York, New York, 824 pp.

Dreier, R. B., T. O. Early, H. L. King. 1993. Results and Interpretation of Groundwater Data Obtained from Multiport-instrumented Coreholes (GW-131 through GW-135), Fiscal Years 1990 and 1991, Y/TS-803, Martin Marietta Energy Systems, Inc., Oak Ridge Y-12 Plant, Oak Ridge, Tennessee.

Energy Systems (Martin Marietta Energy Systems, Inc.). 1987. Post-Closure Permit Application for the S-3 Ponds Hazardous Waste Disposal Unit at the Y-12 Plant, Y/Sub/87-00206C/12, Oak Ridge Y-12 Plant, Oak Ridge, Tennessee.

Energy Systems. 1988. Revised RCRA Closure Plan for the S-3 Ponds, Y/TS-393, Oak Ridge Y-12 Plant, Oak Ridge, Tennessee, February.

Energy Systems. 1993. Oak Ridge Reservation Environmental Report for 1992, Volume 1: Narrative, ES/ESH-31/V1, Oak Ridge National Laboratory, Oak Ridge, Tennessee, September.

Energy Systems. 1994. Environmental Restoration Quality Program Plan, ES/ER/TM-4/R4, September.

EPA (U.S. Environmental Protection Agency). 1990. Basics of Pump-and-Treat Groundwater Remediation Technology, EPA/600/8-90/003.

EPA. 1983. Interim Guidelines and Specifications for Preparing Quality Assurance Project Plans, EPA-600/4-83-004, QAMS-005/80, February.

EPA. 1993. Guidance for Evaluating the Technical Impracticability of Groundwater Restoration, EPA/540/R-93/080.

Foreman, J. L., K. R. Walker, L. J. Weber, S. G. Driese, and R. B. Dreier. 1991. "Slope and Basinal Carbonate Deposition in the Nolichucky Formation (Upper Cambrian) East Tennessee: Effect of Carbonate Suppression by Siliclastic Deposition on Basin Manger Lithologies," Society of Economic Paleontologists and Mineralogists Cave Workshop on Mixed Carbonate-Siliclastic Sequences, SEPM Cave Workshop, No. 15, Dallas, Texas, April 7, pp. 511-539.

Freeze, A. R. and J. A. Cherry. 1979. Groundwater, Prentice-Hall, Inc., Englewood Cliffs, New Jersey. 
Geraghty \& Miller, Inc. 1986. Aquifer Test Data and Design of Recovery Wells, S-3 Ponds, Y/SUB/86-00206C/3, Oak Ridge Y-12 Plant, Martin Marietta Energy Systems, Inc., Oak Ridge, Tennessee, October.

Geraghty \& Miller, Inc. 1987a. Draft Preliminary Design of Recovery-Well Networks for Rapid and Long-Term Groundwater Clean-up Options at the S-3 Ponds, Y/SUB/87-00206C, Oak Ridge Y-12 Plant, Martin Marietta Energy Systems, Inc., Oak Ridge, Tennessee, August.

Geraghty \& Miller, Inc. 1987b. Hydrogeologic Investigations of the S-3 Ponds Area at the Y-12 Plant, Y/SUB/87-00206C/4, Oak Ridge Y-12 Plant, Martin Marietta Energy Systems, Inc., Oak Ridge, Tennessee, October.

Geraghty \& Miller, Inc. 1989a. Development of Contaminant Transport Models for Four Constituents at the S-3 Site, Y-12 Plant, Oak Ridge, Tennessee, Y/SUB/89-00206C/3, Oak Ridge Y-12 Plant, Martin Marietta Energy Systems, Inc., Oak Ridge, Tennessee, June.

Geraghty \& Miller, Inc. 1989b. Development of Groundwater Flow Models for the S-3 Waste Management Area at the Y-12 Plant, Oak Ridge, Tennessee, Y/SUB/89-00206C/1, Oak Ridge Y-12 Plant, Martin Marietta Energy Systems, Inc., Oak Ridge, Tennessee, June.

Golder Associates, Inc. 1988a. Geohydrologic Site Assessment and Computer Model Application, Bear Creek Valley, Oak Ridge Reservation, Contract \#30X-SA706C, Tasks 1-6.

Golder Associates, Inc. 1988b. Task 2, Well Logging and Geohydrologic Testing, Site Characterization and Groundwater Flow Computer Model Application, Bear Creek Valley, Oak Ridge Reservation: Contract \#30X-SA706C, Tasks 1-6.

Haase, C. S. 1991. Geochemical Identification of Groundwater Flow Systems in Fractured Bedrock Near Oak Ridge, Tennessee, proceedings of the focused conference on Eastern Groundwater Issues, pp. 275-288.

Hantush, M. S. and R. G. Thomas. 1966. “A Method for Analyzing a Drawdown Test in Anisotropic Aquifers," Water Resources Research, 2(2): 281-285.

Hatcher, R. D., P. J. Lemiszki, R. B. Dreier, R. H. Ketelle, R. R. Lee, D. A. Leitzke, W. M. McMaster, J. L. Foreman, and S. Y. Lee. 199.2. Status Report on the Geology of the Oak Ridge Reservation, ORNL/TM-12074, Oak Ridge National Laboratory, Martin Marietta Energy Systems, Inc., Oak Ridge, Tennessee.

HSW Environmental Consultants, Inc. 1991. Groundwater Quality Assessment for the Bear Creek Hydrogeologic Regime at the Y-12 Plant, 1990: Data Interpretation and Proposed Modifications for 1991, Y/SUB/91-YP507C/P1\&P2, Oak Ridge Y-12 Plant, Martin Marietta Energy Systems, Inc., Oak Ridge, Tennessee.

HSW Environmental Consultants, Inc. 1992. Groundwater Quality Assessment for the Bear Creek Hydrogeologic Regime at the Y-12 Plant: 1991 Groundwater Quality Data Interpretations and Proposed Program Modifications, Y/Sub/92-YP507C/1/P1\&P2, Oak Ridge Y-2 Plant, Martin Marietta Energy Systems, Inc., Oak Ridge, Tennessee, August. 
HSW Environmental Consultants, Inc. 1993. Groundwater Quality Assessment for the Bear Creek Hydrogeologic Regime at the Y-12 Plant: 1992 Groundwater Quality Data Interpretations and Proposed Program Modifications, Y/Sub/92-YP507C/1/P1\&P2, Oak Ridge Y-12 Plant, Martin Marietta Energy Systems, Inc., Oak Ridge, Tennessee, August.

HSW Environmental Consultants, Inc. 1994a. Groundwater Quality Assessment for the Bear Creek Hydrogeologic Regime at the Y-12 Plant: 1993 Groundwater Quality Data and Calculated Rate of Contaminant Migration, Y/Sub/93-YP507C/1/P1, Oak Ridge Y-12 Plant, Martin Marietta Energy Systems, Inc., Oak Ridge, Tennessee, August.

HSW Environmental Consultants, Inc. 1994b. Calendar Year 1993 Groundwater Quality Report for the Bear Creek Hydrogeologic Regime, Y-12 Plant, Oak Ridge, Tennessee, Y/Sub/94EAQ10C/1/P1, Oak Ridge Y-12 Plant, Martin Marietta Energy Systems, Inc., Oak Ridge, Tennessee.

Jeter, I. W. 1983. The Chemical and Radiological Characterization of the S-3 Ponds, Y/MA-6400, Oak Ridge Y-12 Plant, Union Carbide Corporation Nuclear Division.

Kimbrough, C. W. and R. R. Turner. 1987. Field Notebook: Sampling and Analysis of Sludges in the S-3 Ponds at the Y-12 Plant, Y/TS-294, Martin Marietta Energy Systems, Inc., Oak Ridge Y-12 Plant, Oak Ridge, Tennessee, July.

King, H. L. and C. S. Haase. 1987. Subsurface-controlled Geological Maps for the Y-12 Plant and Adjacent Areas of Bear Creek Valley, ORNL/TM-10112, Oak Ridge National Laboratory, Martin Marietta Energy Systems, Inc., Oak Ridge, Tennessee.

King, H. L. and C. S. Haase. 1988. Summary of Results and Preliminary Interpretation of Hydrogeologic Packer Testing in Coreholes GW-131 through GW-135 and CH-157, Oak Ridge Y-12 Plant, Y/TS-495, Oak Ridge Y-12 Plant, Martin Marietta Energy Systems, Inc., Oak Ridge, Tennessee.

Law Engineering Testing Company. 1983a. Results of Groundwater Monitoring Studies, Y/Sub/83-47936/1, Oak Ridge Y-12 Plant, Union Carbide Corporation, Nuclear Division, Oak Ridge, Tennessee.

Law Engineering Testing Company. 1983b. Stability Analyses of Waste Disposal Facilities, Y-12 Plant, Oak Ridge, Tennessee, Oak Ridge Y-12 Plant, Union Carbide Corporation, Nuclear Division, Oak Ridge, Tennessee.

Lozier W. B., C. A. Spiers, and R. Pearson. 1987. Aquifer Pump Test with Tracers, ORNL/Sub/86-32136/2, Golder Associates, Inc., Oak Ridge National Laboratory, Martin Marietta Energy Systems, Inc., Oak Ridge, Tennessee, October.

McDonald, M. G. and A.W. Harbaugh. 1988. A Modular Three-Dimensional Finite Difference Groundwater Flow Model: Techniques of Water-Resources Investigations of the United States Geological Survey, Book 6, Chap. A1, U.S. Geological Survey.

Moore, G. K. 1988. Concepts of Groundwater Occurrence and Flow Near Oak Ridge National Laboratory, Tennessee, ORNL/TM-10969, Oak Ridge National Laboratory, Martin Marietta Energy Systems, Inc., Oak Ridge, Tennessee. 
Moore, G. K. and L. E. Toran. 1992. Supplement to a Hydrologic Framework for the Oak Ridge Reservation, Oak Ridge, Tennessee, ORNL/TM-12191, Oak Ridge National Laboratory, Martin Marietta Energy Systems, Inc., Oak Ridge, Tennessee.

Parkhurst, D. L., L. N. Plummer, and D. C. Thorstenson. 1980. PHREEQE-A Computer Program for Geochemical Calculations, U.S. Geological Survey, Water-Resources Investigations.

Plummer, L. N., B. F. Jones, and A. H. Truesdell. 1976. WATEQF-A FORTRAN IV Version of WATEQ, A Computer Program for Calculating Chemical Equilibrium of Natural Waters, U.S. Geological Survey, Water-Resources Investigations.

Reeves, M., D. S. Ward, N. D. Johns, and R. M. Cornwell. 1985. Theory and Implementation for SWIFT II, The Sandia Waste Isolation Flow and Transport Model for Fractured Media, NUREG/CR-3328, U.S. Nuclear Regulatory Commission, Washington, D.C.

Shevenell, L. A., G. K. Moore, and R. B. Dreier. 1994. "Contaminant Spread and Flushing in Fractured Rocks Near Oak Ridge, Tennessee," pp. 120-130 in Groundwater Monitoring and Remediation.

Solomon, D. K., G. K. Moore, L. E. Toran, R. B. Dreier, and W. M. McMaster. 1992. Status Report: A Hydrologic Framework for the Oak Ridge Reservation, ORNL/TM-12026, Publication No. 3815, Environmental Sciences Division, Oak Ridge National Laboratory, Martin Marietta Energy Systems, Inc., Oak Ridge, Tennessee.

Toran, L. E. and J. A. Saunders. 1992. Evolution of $\mathrm{NA}-\mathrm{HCO}_{3}$-Type Groundwater Near Oak Ridge, TN: Flow Path and Lithologic Controls, Y/TS-875/R1, Oak Ridge Y-12 Plant, Martin Marietta Energy Systems, Inc., Oak Ridge, Tennessee.

USGS (U.S. Geological Survey). 1991. Hydrogeology and Geochemistry in Bear Creek and Union Valleys near Oak Ridge, Tennessee, Water Resources Investigation Report 90-4008, prepared in cooperation with the U.S. Department of Energy, Nashville, Tennessee. 
Appendix A

HYDRAULIC PROPERTIES AND SUMMARY OF EXISTING MODELS 
Table A.1. Hydraulic testing results summary

\begin{tabular}{|c|c|c|c|c|}
\hline $\begin{array}{l}\text { Test } \\
\text { type }\end{array}$ & $\begin{array}{l}\text { Hydraulic conductivity } \\
\qquad(\mathrm{cm} / \mathrm{s})\end{array}$ & $\begin{array}{c}\text { Transmissivity } \\
\text { (square } \mathrm{m} / \mathrm{s} \text { ) }\end{array}$ & $\begin{array}{c}\text { Storage } \\
\text { coefficient }\end{array}$ & Other \\
\hline Law Engineering, Inc. 1983 & & 3.45E-05 & $3.00 \mathrm{E}-03$ & \\
\hline Geraghty \& Miller, Inc. 1986 pumping test Well 1044 & $1.13 \mathrm{E}-04$ to $2.9 \mathrm{E}-04$ & $1.72 \mathrm{E}-05$ to $4.45 \mathrm{E}-05$ & $5.00 \mathrm{E}-04$ & \\
\hline Geraghty \& Miller, Inc. 1986 pumping test Well GW-104 & 1.47E-03 & 4.02E-05 & & \\
\hline Geraghty \& Miller, Inc. 1986 pumping test Well GW-245 & $1.69 \mathrm{E}-04$ to $1.93 \mathrm{E}-04$ & $1.44 \mathrm{E}-05$ to $1.65 \mathrm{E}-05$ & $2 \mathrm{E}-04$ to $4.0 \mathrm{E}-04$ & $0.24 \mathrm{gpm} / \mathrm{ft}$ specific capacity \\
\hline pumping test well TW & & $\begin{array}{l}9.29 E-05 \\
9.29 E-07\end{array}$ & $6.00 \mathrm{E}-04$ & 0.008 to 0.004 effective porosity \\
\hline
\end{tabular}

Golder and Associates 1988b Packer Tests

GW-136 multiple intervals (Results in Table A.2)

GW-137 multiple intervals (Results in Table A.2)

GW-139 multiple intervals (Results in Table A.2)

GW-401 multiple intervals (Results in Table A.2)

GW-402 multiple intervals (Results in Table A.2)

GW-403 multiple intervals (Results in Table A.2)

GW-468 multiple intervals (Results in Table A.2)

Golder and Associates 1988b Slug Tests

$\begin{array}{ll}\text { GW-136 } & 2.07 \mathrm{E}-06 \\ \text { GW } 403 & 3.98 \mathrm{E}-05 \\ \text { GW-417 } & 1.16 \mathrm{E}-04 \\ \text { GW-419 } & 1.65 \mathrm{E}-05 \\ \text { GW-425 } & 1.40 \mathrm{E}-04 \\ \text { GW-430 } & 9.11 \mathrm{E}-06 \\ \text { GW-439 } & 7.60 \mathrm{E}-05 \\ \text { GW-440 } & 7.08 \mathrm{E}-05 \\ \text { GW-441 } & 1.67 \mathrm{E}-05 \\ \text { GW-452 } & 2.08 \mathrm{E}-05 \\ \text { GW-456 } & 3.64 \mathrm{E}-05\end{array}$


Table A.1 (continued)

\begin{tabular}{|c|c|c|c|c|c|}
\hline Reference & $\begin{array}{l}\text { Test } \\
\text { type }\end{array}$ & $\begin{array}{l}\text { Hydraulic conductivity } \\
(\mathrm{cm} / \mathrm{s})\end{array}$ & $\begin{array}{c}\text { Transmissivity } \\
\text { (square } \mathrm{m} / \mathrm{s} \text { ) }\end{array}$ & $\begin{array}{c}\text { Storage } \\
\text { coefficient } \\
\end{array}$ & Other \\
\hline & GW-457 & $1.92 \mathrm{E}-05$ & & & \\
\hline & $G W-458$ & $3.46 \mathrm{E}-05$ & & & \\
\hline & GW-459 & $1.41 \mathrm{E}-05$ & & & \\
\hline & GW-460 & $2.66 \mathrm{E}-05$ & & & \\
\hline & GW-461 & $1.85 \mathrm{E}-05$ & & & \\
\hline & $G W-462$ & 3.53E-06 & & & \\
\hline & $G W-472$ & $1.61 \mathrm{E}-05$ & & & \\
\hline & Geometric mean & 2.31E-05 & & & \\
\hline \multirow[t]{9}{*}{ Golder and Associates 1988a } & pumping test & & & & \\
\hline & observation wells & & Theis method & Theis method & \\
\hline & GW-456 & $6.21 \mathrm{E}-03$ & $1.95 \mathrm{E}-04$ & $2.10 \mathrm{E}-03$ & \\
\hline & GW-457 & $8.28 \mathrm{E}-04$ & $2.60 \mathrm{E}-05$ & $4.60 \mathrm{E}-04$ & \\
\hline & GW-458 & $4.43 E-04$ & $1.39 E-05$ & $8.80 \mathrm{E}-04$ & \\
\hline & GW-459 & $1.81 \mathrm{E}-02$ & $5.67 \mathrm{E}-04$ & $4.80 \mathrm{E}-03$ & \\
\hline & $G W-450$ & $5.37 \mathrm{E}-04$ & $6.60 E-05$ & $1.30 \mathrm{E}-03$ & \\
\hline & GW-461 & $4.53 \mathrm{E}-03$ & $1.49 \mathrm{E}-04$ & $1.30 \mathrm{E}-03$ & \\
\hline & pumping well: GW-462 & 1.22E-04 & $1.86 \mathrm{E}-05$ & & \\
\hline \multirow[t]{8}{*}{ King and Haase 1988} & Packer tests well GW-134 & & & & Hydraulic head \\
\hline & test interval in $\mathrm{ft}$ below surface & & & & $\mathrm{ft}$ amsl \\
\hline & $173-200$ & $2.87 \mathrm{E}-06$ & & & 984.34 \\
\hline & $270-297$ & $1.74 \mathrm{E}-06$ & & & 988.34 \\
\hline & $360-387$ & $5.14 \mathrm{E}-08$ & & & 1090.77 \\
\hline & $450-477$ & 3.17E-07 & & & 962.96 \\
\hline & $560-587$ & $4.26 \mathrm{E}-07$ & & & 1001.21 \\
\hline & Geometric mean & $5.10 \mathrm{E}-07$ & & & \\
\hline
\end{tabular}


Table A.2. Packer test results from Golder and Associates (1988b)

\begin{tabular}{|c|c|c|c|c|}
\hline \multirow{2}{*}{$\begin{array}{c}\text { Well and test } \\
\text { number }\end{array}$} & \multicolumn{2}{|c|}{$\begin{array}{l}\text { Test Interval } \\
\text { (ft bls) }\end{array}$} & \multirow{2}{*}{$\begin{array}{c}\text { Section of } \\
\text { Nolichucky Shale } \\
\text { tested }\end{array}$} & \multirow{2}{*}{$\begin{array}{c}\text { Log-Log } \\
\text { Hydraulic conductivity } \\
\text { (cm/s) }\end{array}$} \\
\hline & Top & Bottom & & \\
\hline GW-136-1 & 53 & 80 & upper & $6.10 \mathrm{E}-06$ \\
\hline$G W-136-2$ & 113 & 140 & upper & $4.40 \mathrm{E}-06$ \\
\hline$G W-136-3$ & 175 & 202 & middle & $4.50 \mathrm{E}-06$ \\
\hline GW-136-4 & 216 & 243 & middle & $1.50 \mathrm{E}-06$ \\
\hline GW-136-4B & 221 & 248 & middle & $2.80 \mathrm{E}-07$ \\
\hline GW-136-5 & 283 & 310 & middle & $2.40 \mathrm{E}-05$ \\
\hline$G W-136-5 B$ & 288 & 315 & middle & $3.90 \mathrm{E}-05$ \\
\hline GW-136-6 & 420 & 447 & lower & $1.00 \mathrm{E}-05$ \\
\hline GW-136-7 & 501 & 528 & lower & $4.20 \mathrm{E}-07$ \\
\hline$G W-137-3$ & 337 & 364 & upper & $1.40 \mathrm{E}-04$ \\
\hline$G W-137-4$ & 675 & 702 & middle & $1.30 \mathrm{E}-07$ \\
\hline GW-139-1 & 195 & 217 & upper & $5.90 \mathrm{E}-06$ \\
\hline GW-139-2 & 300 & 322 & middle & $1.70 \mathrm{E}-06$ \\
\hline GW-139-3 & 382 & 404 & lower & $2.70 \mathrm{E}-07$ \\
\hline GW-401-1 & 125 & 147 & middle & $8.20 \mathrm{E}-06$ \\
\hline GW-401-2 & 244 & 266 & lower & $1.50 \mathrm{E}-06$ \\
\hline GW-401-3 & 266 & 288 & lower & $6.50 \mathrm{E}-06$ \\
\hline GW-401-4 & 317 & 339 & lower & $7.80 \mathrm{E}-07$ \\
\hline$G W-401-5$ & 386 & 408 & lower & $1.00 \mathrm{E}-05$ \\
\hline$G W-401-10$ & 266 & 273 & lower & $9.50 \mathrm{E}-06$ \\
\hline GW-401-11 & 273 & 280 & lower & $5.30 \mathrm{E}-05$ \\
\hline$G W-401-12$ & 280 & 287 & lower & $3.00 \mathrm{E}-05$ \\
\hline GW-401-13 & 386 & 393 & lower & $1.60 \mathrm{E}-05$ \\
\hline$G W-401-14$ & 393 & 400 & lower & $2.70 \mathrm{E}-05$ \\
\hline GW-401-15 & 400 & 407 & lower & 4.80E-07 \\
\hline GW-401-16 & 448 & 455 & lower & $3.80 \mathrm{E}-05$ \\
\hline GW-402-1 & 110 & 137 & upper & $1.30 \mathrm{E}-05$ \\
\hline$G W-402-2$ & 150 & 177 & upper & $2.50 \mathrm{E}-05$ \\
\hline$G W-402-3$ & 192 & 219 & upper & $1.20 \mathrm{E}-06$ \\
\hline GW-402-4 & 243 & 270 & upper & $2.40 \mathrm{E}-06$ \\
\hline$G W-402-5$ & 270 & 297 & upper & 2.90E-07 \\
\hline$G W-402-11$ & 302 & 329 & upper & $4.60 \mathrm{E}-08$ \\
\hline GW-402-6 & 333 & 360 & upper & $5.50 \mathrm{E}-08$ \\
\hline$G W-402-7$ & 373 & 400 & middle & $1.20 \mathrm{E}-07$ \\
\hline$G W-402-8$ & 403 & 430 & middle & 2.70E-07 \\
\hline GW-402-9 & 525 & 552 & middle & $2.00 \mathrm{E}-07$ \\
\hline$G W-402-10$ & 559 & 586 & middle & $4.40 \mathrm{E}-08$ \\
\hline GW-403-1 & 92 & 114 & lower & $1.60 \mathrm{E}-03$ \\
\hline$G W-403-2$ & 160 & 182 & lower & $7.80 \mathrm{E}-06$ \\
\hline$G W-403-3$ & 234 & 256 & lower & $9.10 \mathrm{E}-05$ \\
\hline GW-403-4 & 275 & 297 & lower & $3.50 \mathrm{E}-05$ \\
\hline$G W-403-5$ & 306 & 328 & contact Nolichucky/Maryville & $4.90 \mathrm{E}-08$ \\
\hline GW-468-2 & 109 & 131 & upper & $1.70 \mathrm{E}-05$ \\
\hline$G W-468-3$ & 138 & 160 & upper & $9.00 \mathrm{E}-05$ \\
\hline$G W-468-4$ & 210 & 232 & upper & $3.40 \mathrm{E}-06$ \\
\hline$G W-468-5$ & 279 & 301 & upper & $1.40 \mathrm{E}-06$ \\
\hline$G W-468-6$ & 355 & 377 & middle & $1.80 \mathrm{E}-05$ \\
\hline$G W-468-7$ & 413 & 435 & middle & $9.40 \mathrm{E}-09$ \\
\hline$G W-468-8$ & 465 & 487 & middle & $1.00 \mathrm{E}-07$ \\
\hline$G W-468-9$ & 109 & 116 & upper & $4.40 \mathrm{E}-05$ \\
\hline & & & Geometric mean & $3.04 \mathrm{E}-06$ \\
\hline
\end{tabular}


Table A.3. Summary of primary flow and contaminant transport models for the S-3 Site ${ }^{a}$

\begin{tabular}{|c|c|c|}
\hline Item & Geraghty \& Miller, Inc. (1989a and b) & USGS (1991) \\
\hline Objectives & $\begin{array}{l}\text { Develop groundwater flow and contaminant } \\
\text { transport model for the aquifer beneath the S-3 Site }\end{array}$ & $\begin{array}{l}\text { Develop a valley-wide conceptual model and simulate } \\
\text { the dynamics of the flow system; demonstrate potential } \\
\text { direction of contaminant migration }\end{array}$ \\
\hline Mathematical Code & $\begin{array}{l}\text { MODFLOW (McDonald and Harbaugh 1988) } \\
\text { SWIFT (Reeves et al. 1985) }\end{array}$ & $\begin{array}{l}\text { MODFLOW (McDonald and Harbaugh 1988) } \\
\text { WATEQF (Plummer et al. 1976) } \\
\text { PHREEQE (Parkhurst et al. 1980) }\end{array}$ \\
\hline \multicolumn{3}{|l|}{ Discretization } \\
\hline Areal coverage $(\mathrm{ft} \times \mathrm{ft})$ & $5000 \times 13,000$ & $5000 \times 80,000$ \\
\hline $\begin{array}{l}\text { Grid cell size (min and max) } \\
\text { (ft) }\end{array}$ & $\begin{array}{l}200 \times 100 \\
200 \times 400\end{array}$ & $\begin{array}{l}250 \times 500 \\
250 \times 1000\end{array}$ \\
\hline Rows $\times$ columns & $65 \times 23$ & NA \\
\hline Number of layers & 5 & 4 \\
\hline Layer thickness (ft) & $30,30,40,100,200$ & $50,50,300$, and 200 \\
\hline Model boundaries & $\begin{array}{l}\text { Pine Ridge on the north and Chestnut Ridge on the } \\
\text { south, } 7000 \mathrm{ft} \text { to the west and } 6000 \mathrm{ft} \text { to the east of } \\
\text { the S-3 Ponds }\end{array}$ & $\begin{array}{l}\text { Clinch River both in the east and the west, Pine Ridge } \\
\text { in the north, and Chestnut Ridge in the south }\end{array}$ \\
\hline $\begin{array}{l}\text { Bottom of the model ( } \mathrm{ft} \text { below } \\
\text { water table) }\end{array}$ & 400 & 600 \\
\hline \multicolumn{3}{|l|}{ Features } \\
\hline Subsurface storm flow zone & No & No \\
\hline Water table fluctuation zone & No & No \\
\hline Deep groundwater & Yes & Yes \\
\hline Disposal areas & No & No \\
\hline Transient/steady state & Steady state & Steady state \\
\hline
\end{tabular}


Table A.3 (continued)

\begin{tabular}{|c|c|c|}
\hline Item & Geraghty \& Miller, Inc. (1989a and b) & USGS (1991) \\
\hline Fracture & No & No \\
\hline Matrix diffusion & No & No \\
\hline \multicolumn{3}{|l|}{ Hydraulic parameters } \\
\hline Hydrologic units & $\begin{array}{l}5 \text { hydrologic units: Copper Ridge Dolomite (Knox } \\
\text { Group), Maynardville Limestone, Nolichucky } \\
\text { Shale, Maryville Limestone, and Pumpkin Valley } \\
\text { Shale }\end{array}$ & $\begin{array}{l}7 \text { hydrologic units: Copper Ridge Dolomite (Knox } \\
\text { Group), Maynardville Limestone, Nolichucky Shale, } \\
\text { Maryville Limestone, Rogersville Shale and Rutledge } \\
\text { Limestone, Pumpkin Valley Shale, and Rome } \\
\text { Formation }\end{array}$ \\
\hline Conductivity & $\begin{array}{l}\text { Homogeneous and anisotropic by layer within each } \\
\text { hydrogeologic unit (see Table A.4) }\end{array}$ & $\begin{array}{l}\text { Homogeneous and isotropic by layer within each } \\
\text { hydrogeologic unit (see Table A.4) }\end{array}$ \\
\hline Anisotropic ratio & 3 & 1 \\
\hline Recharge & $\begin{array}{l}\text { Uniform, } 12 \mathrm{in.} / \text { year throughout the valley, and } \\
3.6 \mathrm{in} . / \text { year in the plant area }\end{array}$ & $\begin{array}{l}5 \mathrm{in} . / \text { year in the Pine Ridge, } 4 \text { in./year in the Chestnut } \\
\text { Ridge, and } 0 \text { in./year in the valley }\end{array}$ \\
\hline Boundary conditions & $\begin{array}{l}\text { No-flow boundaries along the ridges and constant } \\
\text { head at east and west model boundaries based on } \\
\text { valley-wide model, also no-flow at the bottom of } \\
\text { the model }\end{array}$ & $\begin{array}{l}\text { The Clinch River was simulated as constant head } \\
\text { boundary in Layer } 1 \text { at each end of the model, no-flow } \\
\text { along the ridges, and at the bottom of the model }\end{array}$ \\
\hline \multicolumn{3}{|l|}{ Results } \\
\hline Water level match & $\begin{array}{l}\text { Hydraulic heads are within } \pm 10 \mathrm{ft} \text { of the observed } \\
\text { head at } 114 \text { of the } 122 \text { calibration targets, and } \\
\pm 5 \mathrm{ft} \text { at } 86 \text { of } 122 \text { wells }\end{array}$ & $\begin{array}{l}73 \% \text { of hydraulic heads (of } 132 \text { wells used for } \\
\text { calibration) are within } \pm 10 \mathrm{ft} \text { of the observed head } \\
\text { (normal range of seasonal water level fluctuation); } \\
\text { average head difference is }-1.7 \mathrm{ft}\end{array}$ \\
\hline Water level match (RMS) & $5.93 \mathrm{ft}$ & $\begin{array}{l}\text { The overall RMSE is } 14 \mathrm{ft} \text { for all layers, } 15.3 \mathrm{ft} \text { for } \\
\text { Layer } 1,10.2 \mathrm{ft} \text { for Layer } 2,16.3 \mathrm{ft} \text { for Layer } 3 \text {, and } \\
13.5 \mathrm{ft} \text { for Layer } 4\end{array}$ \\
\hline $\begin{array}{l}\text { Outflow from the modeled } \\
\text { system (percent) }\end{array}$ & & $\begin{array}{l}5 \% \text { through modeled boundaries at the Clinch River, } \\
72 \% \text { through seepage to the main streams, and } 23 \% \text { to } \\
\text { tributaries }\end{array}$ \\
\hline
\end{tabular}


Table A.3 (continued)

\begin{tabular}{|c|c|c|c|}
\hline Item & Geraghty \& Miller, Inc. (1989a and b) & USGS (1991) & \\
\hline \multicolumn{4}{|l|}{ Sensitivity: Flow Model } \\
\hline Recharge & Sensitive & Very sensitive & \\
\hline Hydraulic conductivity & Very sensitive & Very sensitive to hydraulic conductivity of the layers & \\
\hline Vertical conductance & NA & Insensitive to wide range of vertical conductance & \\
\hline Boundary conditions & $\begin{array}{l}\text { Very sensitive to constant head values at the } \\
\text { boundaries }\end{array}$ & NA & \\
\hline Anisotropy & Moderately sensitive & $\begin{array}{l}\text { Sensitive, but ratios }>1.25 \text { or }<1 \text { produced larger } \\
\text { RMSE values }\end{array}$ & \\
\hline \multicolumn{4}{|l|}{ Contaminant transport } \\
\hline Contaminants modeled & Nitrate, uranium, cadmium, and tetrachloroethene & $\begin{array}{l}\text { Geochemical nature of the groundwater was } \\
\text { investigated }\end{array}$ & \multirow{3}{*}{$\underset{\infty}{\infty}$} \\
\hline Calibrated parameters & $\begin{array}{l}\text { Effective porosity: } 0.09 \text { to } 0.15 \\
\text { Longitudinal dispersivity: } 100 \\
\text { Transverse dispersivity: } 100 \\
\text { Distribution coefficients }(\mathrm{mL} / \mathrm{g}) \text { : } \\
\text { nitrate }=0.0, \text { uranium }=0.4, \\
\text { cadmium }=0.2 \text {, dichloroethene }=0.4\end{array}$ & NA & \\
\hline Results & $\begin{array}{l}\text { In some areas the models simulated well; in other } \\
\text { areas it failed completely; for tetrachloroethene, the } \\
\text { match with observed data was very poor }\end{array}$ & $\begin{array}{l}\text { Two distinct zones of water chemistry: } 0 \text { to } 50 \mathrm{ft} \text {, and } \\
50 \text { to } 500 \mathrm{ft} \text { below ground surface; } \\
\text { dissolved solids in deeper zone } 15,000 \mathrm{mg} / \mathrm{L} \text { and } \\
20,000 \mathrm{mg} / \mathrm{L} \text { in shallow zone }\end{array}$ & \\
\hline
\end{tabular}


Table A.3 (continued)

\begin{tabular}{|c|c|c|c|}
\hline Item & \multicolumn{2}{|l|}{ Geraghty \& Miller, Inc. (1989a and b) } & USGS (1991) \\
\hline \multicolumn{4}{|l|}{ Sensitivity: Transport Models } \\
\hline Source concentration & \multicolumn{2}{|l|}{ Slightly sensitive } & NA \\
\hline Distribution coefficient $\left(\mathrm{K}_{\imath}\right)$ & \multicolumn{2}{|c|}{$\begin{array}{l}\text { Uranium, cadmium, and tetrachloroethene models } \\
\text { were highly sensitive to changes in } K_{d}\end{array}$} & NA \\
\hline Effective porosity & \multicolumn{2}{|l|}{ Very sensitive } & NA \\
\hline Dispersivity & \multicolumn{2}{|c|}{$\begin{array}{l}\text { Moderately sensitive, but less sensitive to ratio of } \\
\text { dispersivities }\end{array}$} & NA \\
\hline Conclusions & $\begin{array}{l}\text { More representative } \mathrm{K}_{\mathrm{d}} \text { values are needed; } \\
\text { source should be well characterized; } \\
\text { water quality data from various depths; } \\
\text { better estimates of effective porosity; } \\
\text { better estimates of dispersivity; } \\
\text { preferential flow and transport investigation; } \\
\text { a large-scale long-term pump test; } \\
\text { a more detailed and accurate water budget }\end{array}$ & 1 & $\begin{array}{l}\text { Continuous flow system to depth of at least } 50 \mathrm{ft} \text {. Short } \\
\text { flow paths along strike (parallel to the valley axis) are } \\
\text { controlled by closely spaced tributaries normal to } \\
\text { strike, or by localized fractures and solution features } \\
\text { oriented along strike. Maynardville Limestone is more } \\
\text { likely than any other formation to provide a pathway } \\
\text { for contaminant transport over long distances. In the } \\
\text { Bear Creek watershed, contaminants transported by } \\
\text { groundwater to the Maynardville Limestone could be } \\
\text { discharged to Bear Creek and transported down the } \\
\text { valley by the stream or transported by the groundwater } \\
\text { along the strike of the formation through fractures and } \\
\text { solution openings. }\end{array}$ \\
\hline \multicolumn{3}{|c|}{$\begin{array}{l}{ }^{a} \text { Abbreviations used are defined as follows: } \\
\text { NA = not available } \\
\text { MODFLOW = Modular Three-dimensional Finite-Difference Groundwater Flow Model } \\
\text { PHREEQE = pH-redox-equilibrium-equations } \\
\text { RMS = root mean square } \\
\text { RMSE = root mean square error } \\
\text { SWIFT = Sandia Waste Isolation Flow and Transport } \\
\text { USGS = U.G. Geological Survey } \\
\text { WATEQF = water equilibrium-FORTRAN }\end{array}$} & $i$ \\
\hline
\end{tabular}


Table A.4. Summary of calibrated hydraulic conductivities of the USGS and Geraghty \& Miller, Inc. models

\begin{tabular}{|c|c|c|c|c|c|}
\hline \multirow[b]{2}{*}{ Unit } & \multirow[b]{2}{*}{ Model layer } & \multicolumn{2}{|c|}{ Geraghty \& Miller, Inc. } & \multicolumn{2}{|c|}{ USGS } \\
\hline & & $\mathrm{cm} / \mathrm{s}$ & 1989 & $\mathrm{~cm} / \mathrm{s}$ & 1991 \\
\hline \multirow[t]{5}{*}{ Knox Group } & 1 & & $1.48 \mathrm{E}-05$ & & $1.09 \mathrm{E}-05$ \\
\hline & 2 & & $1.83 E-05$ & & $1.09 E-05$ \\
\hline & 3 & & $1.66 \mathrm{E}-05$ & & $1.09 \mathrm{E}-06$ \\
\hline & 4 & & 8.4.7E-06 & & $2.82 \mathrm{E}-07$ \\
\hline & 5 & & 4.23E-06 & NA & \\
\hline \multirow[t]{5}{*}{ Maynardville Limestone } & 1 & & $6.17 \mathrm{E}-04$ & & $1.38 \mathrm{E}-05$ \\
\hline & 2 & & 7.73E-04 & & $1.38 \mathrm{E}-05$ \\
\hline & 3 & & $6.95 \mathrm{E}-04$ & & $1.38 \mathrm{E}-06$ \\
\hline & 4 & & $3.4 .9 \mathrm{E}-04$ & & 2.82E-07 \\
\hline & 5 & & $1.73 \mathrm{E}-04$ & NA & \\
\hline \multirow[t]{5}{*}{ Nolichucky Shale } & 1 & & 2.72E-04 & & $2.08 E-05$ \\
\hline & 2 & & 3.39E-04 & & $2.08 \mathrm{E}-05$ \\
\hline & 3 & & 3.03E-04 & & $2.08 \mathrm{E}-06$ \\
\hline & 4 & & $1.52 \mathrm{E}-04$ & & 2.02E-07 \\
\hline & 5 & & $7.76 \mathrm{E}-05$ & NA & \\
\hline \multirow[t]{5}{*}{ Maryville Limestone } & 1 & & $1.16 \mathrm{E}-04$ & & $1.20 \mathrm{E}-05$ \\
\hline & 2 & & $1.45 \mathrm{E}-04$ & & $1.20 \mathrm{E}-05$ \\
\hline & 3 & & $1.31 \mathrm{E}-04$ & & $1.20 \mathrm{E}-06$ \\
\hline & 4 & & $6.35 \mathrm{E}-05$ & & 2.82E-07 \\
\hline & 5 & & $3.25 \mathrm{E}-05$ & NA & \\
\hline Rogersville Shale & 1 & NA & & & $1.31 \mathrm{E}-05$ \\
\hline \multirow[t]{4}{*}{ Rutledge Limestone } & 2 & NA & & & $1.31 \mathrm{E}-05$ \\
\hline & 3 & NA & & & $1.31 \mathrm{E}-06$ \\
\hline & 4 & $\mathrm{NA}$ & & & $2.82 \mathrm{E}-07$ \\
\hline & 5 & NA & & NA & \\
\hline \multirow[t]{5}{*}{ Pumpkin Valley Shale } & 1 & & $3.10 \mathrm{E}-05$ & & $5.64 E-06$ \\
\hline & 2 & & 3.88E-05 & & $5.64 \mathrm{E}-06$ \\
\hline & 3 & & 3.49E-05 & & $5.64 \mathrm{E}-07$ \\
\hline & 4 & & $1.73 \mathrm{E}-05$ & & $2.82 \mathrm{E}-07$ \\
\hline & 5 & & 8.82E-06 & NA & \\
\hline \multirow[t]{5}{*}{ Rome Formation } & 1 & NA & & & 1.06E-04 \\
\hline & 2 & NA & & & $1.06 E-04$ \\
\hline & 3 & NA & & & $1.06 \mathrm{E}-05$ \\
\hline & 4 & NA & & & $2.82 \mathrm{E}-07$ \\
\hline & 5 & NA & & NA & \\
\hline
\end{tabular}




\section{DISTRIBUTION}

1. D. G. Cope

2. C. S. Haase

3. J. A. Hodgins

4. W. K. Jago

5. H. L. King

6-7. A. K. Lee/DOE-OSTI

8-10. D. M. Matteo

11. L. W. McMahon

12. H. C. Newsom/D. C. White

13. B. D. Nourse

14-15. P. T. Owen

16. R. J. Spence

17. T. S. Tison

18. C. S. Walker

19. D. B. Watson

20. R. K. White

21. Y-12 Technical Library

22-24. ER Document Management Center

25. Y-12 ER Document Management Center

26. Y-12 Central Files

27. Central Research Library

28. R. C. Sleeman, DOE Oak Ridge Operations Office, P.O. Box 2001, Oak Ridge, TN 37831-8541

29-38. S. L. Lankford, DOE Oak Ridge Operations Office, P.O. Box 2001, Oak Ridge, TN 37831-8541

39. T. Pickens, Science Applications International Corporation, P.O. Box 2501, 800 Oak Ridge Turnpike, Oak Ridge, TN 37831 